CATAL. REV. - SCI. ENG., 32(3), 163-227 (1990)

\title{
Conversion of Methane by Oxidative Coupling
}

\author{
YOSHIMITSU AMENOMIYA* \\ Department of Chemistry \\ University of Ottawa \\ Ottawa, Ontario, Canada K1N 6N5
}

VIOLA I. BIRSS AND MACIEJ GOLEDZINOWSKI $†$

Department of Chemistry

University of Calgary

Calgary, Alberta, Canada T2N 1N4

JAN GALUSZKA

Energy Research Laboratories, CANMET

Energy, Mines and Resources Canada

555 Booth Street

Ottawa, Ontario, Canada K1A 0G1

ALAN R. SANGER

Coal and Hydrocarbon Processing Department

Alberta Research Council

1 Oilpatch Drive

P.O. Bag 1310, Devon, Alberta, Canada T0C 1E0

*To whom correspondence should be directed.

†On leave from the University of Warsaw, Department of Chemistry, Pasteura 1, 02093 Warsaw, Poland. 
I. INTRODUCTION . . . . . . . . . . . . . . . . . . 164

II. CATALYTIC PERFORMANCE . . . . . . . . . . . 167

A. Mode of Operation . . . . . . . . . . . . . . 167

B. Catalysts . . . . . . . . . . . . . . . . . . . . 168

C. Evaluation of Catalytic Activity . . . . . . . . 183

III. MECHANISM OF REACTION . . . . . . . . . . 188

A. Activation of Methane . . . . . . . . . . . . . . . 188

B. Reaction Mechanism . . . . . . . . . . . . 191

C. Kinetics . . . . . . . . . . . . . . . 196

D. Rate-Determining Step . . . . . . . . . . . 198

IV. OPTIMIZATION OF $\mathrm{C}_{2}$ YIELD . . . . . . . . . . 200

A. Catalysts . . . . . . . . . . . . . . . . 201

B. Reaction Conditions . . . . . . . . . . . . 205

V. METHANE CONVERSION IN RELATED

PROCESSES . . . . . . . . . . . . . . . . . . . . . . . 208

A. Conversion by Superacid . . . . . . . . . . . . . . 208

B. Conversion Via Oxychlorination . . . . . . . . . 209

C. Electrochemical Conversion . . . . . . . . . 210

VI. CONCLUSIONS . . . . . . . . . . . . . . . . . . 216

ACKNOWLEDGMENTS . . . . . . . . . . . 217

REFERENCES . . . . . . . . . . . . . 217

\section{INTRODUCTION}

Methane is the major component of natural gas, an inexpensive and accessible energy source. The world reserve of natural gas is estimated as about $10^{14} \mathrm{~m}^{3}$ [1]; this has a significant impact on the world's energy balance. Nonmethane hydrocarbon components of natural gas are usually separated for use as specialty fuels or as feedstocks for chemical processes. For strategic or economic reasons it may be undesirable to transport natural gas to potential markets, or desirable to manufacture liquid transportation fuels from sources other than oil or coal liquids. To this end various routes to the formation of higher hydrocarbons from $\mathrm{C}_{1}$ feedstocks have been investigated.

The first major advance in commercial liquid fuel production from methane since the Fischer-Tropsch technology was achieved by the 
Mobil Corp. by developing the MTG process with the ZSM-5 catalyst. As in the case of Fischer-Tropsch technology, the Mobil process requires steam reforming of methane to produce synthesis gas, which is then converted to methanol. Methanol is reacted to form gasoline selectively over ZSM-5. Analysis of the economics of these processes reveals that a majority of the costs are associated with synthesis gas generation. Obviously, direct methane conversion to higher hydrocarbons seems to be one reasonable way to overcome this economic problem.

There are difficulties in the direct conversion, mainly due to the high stability of the methane molecule and the thermodynamic disadvantages. For example, the dehydrogenation-oligomerization of methane has a large positive change in free energy as

$$
2 \mathrm{CH}_{4}=\mathrm{C}_{2} \mathrm{H}_{6}+\mathrm{H}_{2} \quad \Delta \mathrm{G}^{\circ}=71.0 \mathrm{~kJ} \mathrm{~mol}^{-1} \text { at } 1000 \mathrm{~K}
$$

However, the thermodynamic disadvantage can be overcome by introducing an oxidant as

$$
2 \mathrm{CH}_{4}+\frac{1}{2} \mathrm{O}_{2}=\mathrm{C}_{2} \mathrm{H}_{6}+\mathrm{H}_{2} \mathrm{O} \quad \Delta \mathrm{G}^{\circ}=-121.6 \mathrm{~kJ} \mathrm{~mol}^{-1} \text { at } 1000 \mathrm{~K}
$$

Theoretically this oxidative condensation reaction can proceed further in the reactor to produce higher hydrocarbons. Practically, however, the products are almost limited to $C_{2}$ compounds, as will be seen in the present review. The free energy changes for several reactions related to the direct conversion of methane are shown in Fig. 1. The oxidative condensation (curves 2, 4, and 6) is thermodynamically much more favorable than the dehydrogenation-oligomerization reaction over the entire temperature range. On the other hand, the complete oxidation of methane and hydrocarbon products to carbon dioxide readily takes place in the presence of oxygen. Therefore, the selectivity is one of the key issues in the successful development of the oxidative condensation.

The oxidative condensation of methane, reaction (2), is conventionally called the oxidative coupling of methane. We also use the word coupling in this review. Since the pioneering work of Keller and Bhasin [3], the oxidative coupling of methane leading to higher hydrocarbons has received much attention. Recently, Lee and Oyama [4] published an excellent review on this reaction which is very useful in obtaining information on the methane coupling reported up to early 1987 . Since then, however, a large number of papers have been published on this 


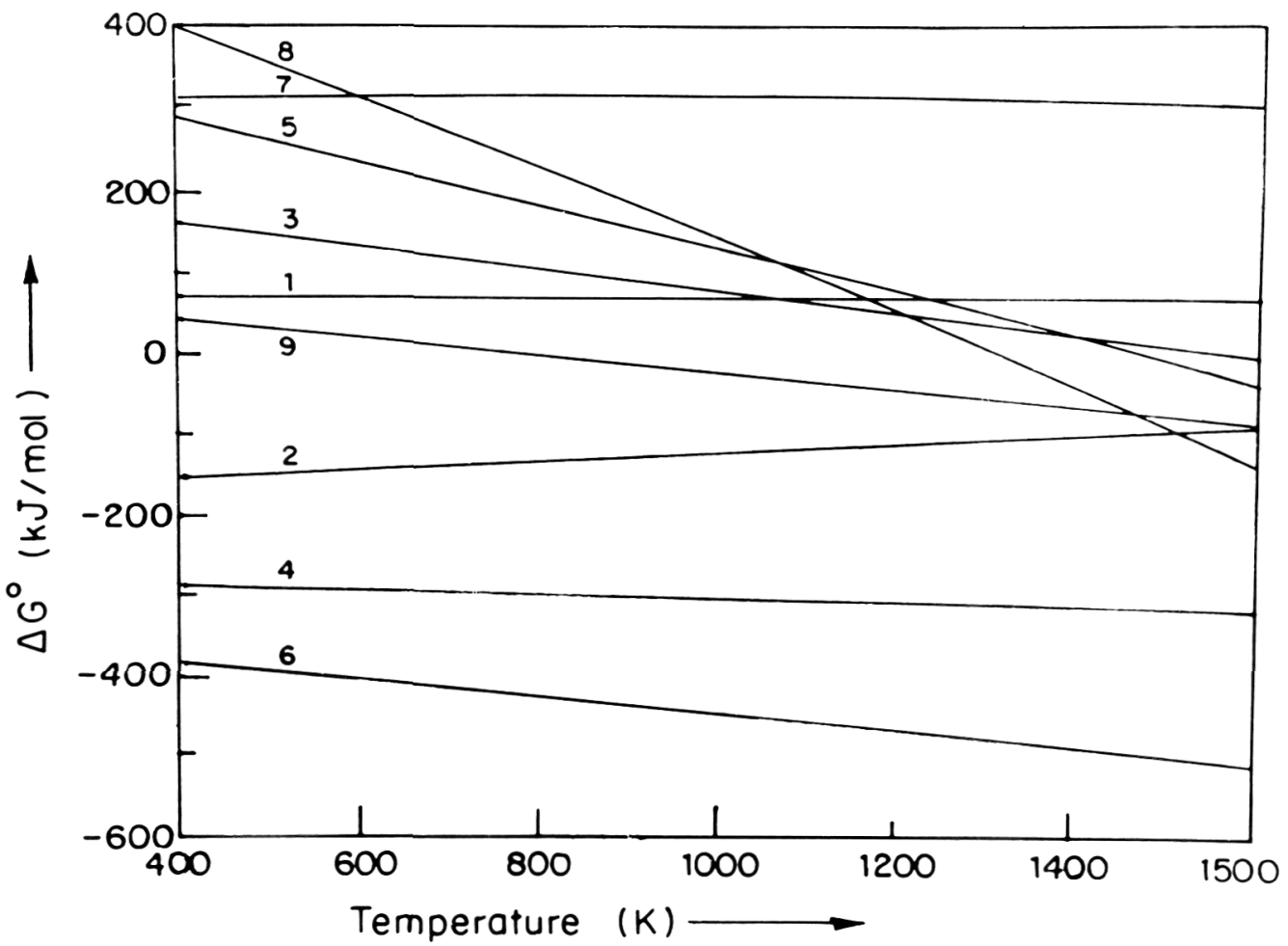

FIG. 1. Temperature dependence of the change in free energy for selected methane conversion reactions: (1) $2 \mathrm{CH}_{4} \rightarrow \mathrm{C}_{2} \mathrm{H}_{6}+\mathrm{H}_{2} ;$; (2) $2 \mathrm{CH}_{4}+\frac{1}{2} \mathrm{O}_{2} \rightarrow \mathrm{C}_{2} \mathrm{H}_{6}+\mathrm{H}_{2} \mathrm{O}$; (3) $2 \mathrm{CH}_{4} \rightarrow \mathrm{C}_{2} \mathrm{H}_{4}+2 \mathrm{H}_{2}$; (4) $2 \mathrm{CH}_{4}+\mathrm{O}_{2} \rightarrow \mathrm{C}_{2} \mathrm{H}_{4}+2 \mathrm{H}_{2} \mathrm{O}$; (5) $2 \mathrm{CH}_{4} \rightarrow \mathrm{C}_{2} \mathrm{H}_{2}+3 \mathrm{H}_{2} ; \quad$ (6) $2 \mathrm{CH}_{4}+1 \frac{1}{2} \mathrm{O}_{2} \rightarrow \mathrm{C}_{2} \mathrm{H}_{2}+3 \mathrm{H}_{2} \mathrm{O}$; (7) $6 \mathrm{CH}_{4} \rightarrow \mathrm{C}_{6} \mathrm{H}_{14}+5 \mathrm{H}_{2} ; \quad$ (8) $6 \mathrm{CH}_{4} \rightarrow \mathrm{C}_{6} \mathrm{H}_{6}+9 \mathrm{H}_{2}$; $\mathrm{CH}_{4} \rightarrow($ Graphite $)+2 \mathrm{H}_{2}$. Calculated from JANAF Thermochemical Tables [2]. 
subject and significant progress has been made. The objective of the present review is to evaluate the current status of knowledge of the oxidative coupling of methane and hopefully to provide a useful guide for future research. Included also in the review are other processes for methane conversion related to the coupling reaction. However, the partial oxidation reactions of methane which produce mainly oxygenated compounds are beyond the scope of the present review. These reactions use different types of catalysts and employ more moderate reaction conditions, as reviewed by Pitchai and Klier [5].

The following definitions of terms and units are used throughout the present work. The term $\mathrm{C}_{2}$ represents both ethane and ethylene while $\mathrm{C}_{2+}$ includes all higher hydrocarbons as well as $\mathrm{C}_{2}$. The total oxidation of methane to water and carbon oxides always accompanies the oxidative coupling reaction. This undesirable side reaction is called nonselective oxidation in this report and the products $\mathrm{CO}_{2}+\mathrm{CO}$ will be generally represented by $\mathrm{CO}_{x}$. The word conversion is used to indicate the conversion of methane unless otherwise stated, and this is expressed as the fraction of methane reacted. Also the selectivity to $\mathrm{C}_{2}$ products is often designated simply as selectivity, defined as the ratio of the number of moles of methane converted to $\mathrm{C}_{2}$ to the total number of moles of methane reacted. The yield is the product of the conversion and the selectivity. The conversion, selectivity, and yield are all expressed in percentages. The contact time has been represented by a time constant, $W / F$ (the weight of catalyst divided by the flow rate), expressed in $\mathrm{g} \cdot \mathrm{sec} \cdot \mathrm{mL}^{-1}$. The space time yield of $\mathrm{C}_{2}$ is abbreviated to $S T Y$ and expressed in $\mu \mathrm{mol} \cdot \mathrm{sec}^{-1} \cdot \mathrm{g}^{-1}$.

\section{CATALYTIC PERFORMANCE}

\section{A. Mode of Operation}

\section{Cyclic Feed}

In 1982 Keller and Bhasin reported the first systematic screening of metal oxides for the oxidative coupling of methane [3]. They obtained most of the results by a cyclic feeding of reactants. The catalysts were first oxidized by air followed by a short period of flushing with nitrogen; then methane was fed to the reactor. Generally, in the cyclic process, in which the reactants are fed sequentially, only one reactant gas is fed to the reactor at a time. Since methane is fed without oxygen, nonselec- 
tive oxidation in the gas phase does not occur. This also ensures safe operation. On the other hand, the catalysts must retain oxygen until methane is introduced. For this reason the materials are generally limited to reducible oxides. Since the oxides are reduced during the reaction, they are not catalysts and the reaction is stoichiometric instead of catalytic. As a result, the coupling reaction is not steady-the conversion and selectivity change with time. Because of these features, only a few studies have employed the cyclic mode [6-12], mainly for the mechanistic study of the reaction. Some oxides, however, have been claimed in patents for the cyclic process of oxidative coupling [13]. As the oxidation and reduction of oxides are repeated alternately, this mode of operation is often called redox cycle.

\section{Cofeed}

Since Hinsen et al. [14] first reported high selectivities for the $C_{2}$ hydrocarbons by simultaneously feeding methane and oxygen over lead oxide catalysts, most investigations have used the cofeed mode of reaction. Usually a high ratio of methane to oxygen is employed to stay outside of the explosion limit. A diluent such as nitrogen or helium is often used, with or without inert solid materials mixed with the catalyst, to control the large heats of reaction from the coupling and nonselective oxidation reactions. Unless otherwise mentioned, results discussed in the present review were all obtained using a cofeed of reactants.

The reaction temperature employed for the oxidative coupling of methane is high, generally in the $900-1200 \mathrm{~K}$ range. Therefore, homogeneous reactions could also occur, and the volume of the gas phase in the reactor may play an important role in the reaction. Reactors of various designs have been used to minimize the empty space in the reactor $[15,16]$.

\section{B. Catalysts}

\section{General Considerations}

A large number of compounds have been tried as catalysts for the oxidative coupling of methane, and it is impossible to classify those materials unambiguously into distinct groups. Nevertheless, they are divided here into three major groups by periodic table location as a matter of convenience: (i) alkali and alkaline earth metal compounds; (ii) the compounds of lanthanide and actinide metals; and (iii) other metal compounds. The third group may be further divided into the compounds of transition metals and those of posttransition metals. 
Since Lunsford and his co-workers [17, 18] first demonstrated that lithium-doped magnesia was an active and selective catalyst for the oxidative coupling reaction, alkali metal-doped alkaline earth metal oxide catalysts have been studied by many workers. These catalysts are often called alkali-promoted magnesia, alkali-promoted calcium oxide, and so on. However, the active centers of, for example, an $\mathrm{Li} / \mathrm{MgO}$ catalyst were found to be the surface $\mathrm{Li}^{+}-\mathrm{O}^{-}$species, as discussed later. It seems, therefore, more appropriate to call it magnesia-supported lithium oxide catalyst. Nonetheless, the terms promoter and support are used conventionally in this review since the active centers are not always identified.

In 1981 Fang and Yeh [19] reported the formation of higher hydrocarbons by passing methane over a $\mathrm{Th} / \mathrm{SiO}_{2}$ catalyst at $1073 \mathrm{~K}$ with or without nitric oxide. This is probably the earliest paper reporting the oxidative coupling of methane. Otsuka et al. [20] made the first systematic comparison of catalytic performance for methane coupling over the oxides of rare earth elements and some other metal oxides. Since then, many investigations have been reported with the rare earth metal oxides, of which lanthanum and samarium oxides were studied most extensively.

From the screening of a number of metal oxides, Keller and Bhasin [3] found that many metal oxides showed activity for the coupling reaction. Generally, metals in the most active group have multiple oxidation states and most of them belong to the low melting metal part of the periodic table. PbO-based catalysts have been used most often in this group since Hinsen, Bytyn, and Baerns [14] reported their successful results with $\mathrm{PbO}$.

Although the catalytic materials are classified in the preceding major groups, it is often difficult to discuss each group separately because almost all types of combinations of these materials have been tried. For example, alkali-promoted rare earth metal oxides, magnesia-supported lead oxide, and lanthanum oxide-supported lead oxide are all active and selective catalysts. Again, the domains of promoter and support are not clear. Bearing these facts in mind, the catalytic materials are considered by groups in the following sections.

\section{Alkali and Alkaline Earth Metals}

Since lithium-doped magnesia was reported as an effective catalyst for methane coupling by Lunsford and his co-workers as mentioned above [17, 18], alkali-doped alkaline earth metal oxides have been studied by many investigators [21-35]. The unpromoted oxides of the 
alkaline earth metals are themselves active for oxidative coupling of methane [23-27]. Doping with a proper alkali metal, however, increases the conversion and selectivity significantly. A combination of lithium and magnesia is most frequently used as the doped system [17, 18, 21, $22,26,28,30-33]$. Various salts of alkali metals including alkali halides $[28,30]$ are used as precursor of dopant. The doped systems designated $\mathrm{Li} / \mathrm{MgO}$ and $\mathrm{Na} / \mathrm{CaO}$ are in fact not alkali metals deposited in alkaline earth oxides. When the radii of both cations are very close, as in the case of $\mathrm{Li}^{+}(0.68 \AA)$ and $\mathrm{Mg}^{2+}(0.66 \AA)$, the replacement of alkaline earth metal by alkali metal can take place [17]. Such substitution by monovalent ion for divalent ion in the lattice of the oxide to form a true mixed oxide requires that an equivalent number of $\mathrm{O}^{-}$radical ions be present to maintain electrical neutrality. These radical ions have been detected by EPR and proved to be the source of the catalytic activity [32], as is discussed in section III.A in more detail.

Although less selective than optimum Li systems, other alkali metals have also been shown to be highly effective in promoting $\mathrm{MgO}[26$, $33-35$ ]. For $\mathrm{Na} / \mathrm{MgO}$, up to $22.4 \% \mathrm{C}_{2}$ yields have been reported [33, 34]. The combination of $\mathrm{Li}$ and lanthanide ( $\mathrm{La}, \mathrm{Ce}, \mathrm{Nd}$, or $\mathrm{Sm}$ ) promoters for $\mathrm{MgO}$ gives spectacular selectivity to $\mathrm{C}_{2+}(98.4 \%)$ at conversions to $25 \%$, and the catalysts are stable to time on stream [26]. For Pr even higher conversions are reported, but with lower selectivity to $\mathrm{C}_{2}$ [26]. Doping magnesia with magnesium and calcium halides, particularly chloride and bromide, seems effective [28].

Other alkaline earth oxides, Group 3 metal, transition metal, or posttransition metal oxide admixes, as supports or promoters, do not seem to be as effective as $\mathrm{Li}$ in promoting $\mathrm{MgO}$, with the notable exceptions of $\mathrm{Mn} / \mathrm{MgO}$ promoted with $\mathrm{Na}[12]$ and a mixed $\mathrm{PbO}-\mathrm{MgO}$ catalyst [36]. For the latter system selectivity to $\mathrm{C}_{2+}$ greater than $80 \%$ is attainable, but only at low oxygen/methane ratios. The catalyst also operates in a cyclic mode, but the productivity is up to 40 times higher under cofeed conditions [36]. The $\mathrm{Mn} / \mathrm{MgO}$ system, which more properly falls within a discussion of the transition metals, is highly effective. In the solid-state domains of $\mathrm{Mg}_{6} \mathrm{MnO}_{8}$ other phases are formed, and appear to be the active components [12]. These results suggest that other such mixed metal oxide phases would be worth the significant effort required for their study as catalysts.

For other metals, including those effective as the coupling catalysts in their own right, basic supports have been identified as important [37], as discussed in section IV.A. Thus the alkaline earth oxides, including $\mathrm{MgO}$, have received wide attention as basic supports, sometimes promoted with alkali metals [35, 38-42]. 
Beryllium oxide itself is not as selective to $C_{2}$ as other alkali earth metal oxides [25], but when doped with $\mathrm{Li}$ it shows a high selectivity $(63 \%)$ at a conversion of $24 \%$ [29].

Although calcium oxide is less studied compared with magnesia, it is an effective catalyst, especially promoted with alkali metals $[21,23$, 25]; $\mathrm{Na}^{+}$and $\mathrm{Ca}^{2+}$ have similar radii $(0.97 \AA$ vs $0.99 \AA)$, and the analogy between " $\mathrm{Na} / \mathrm{CaO}$ " and " $\mathrm{Li} / \mathrm{MgO}$ " has been drawn. In general, catalysts comprising alkali metal salts on $\mathrm{CaO}$ are of low surface area. The effectiveness and product distribution (ethane, ethylene, $\mathrm{C}_{3+}$, $\mathrm{CO}_{x}$ ) vary with both the alkali metal and the anion, but not over a wide range of values. Addition of lanthanum to $\mathrm{Na}_{2} \mathrm{O} / \mathrm{CaO}$ does not have a significant effect $[23,25]$. $\mathrm{CaO}$ doped with magnesium or calcium halides is also an effective catalyst [28].

Similarly, $\mathrm{SrO}$ and $\mathrm{SrCO}_{3}$ have been used effectively both alone and promoted with alkali metal $[23-25,43]$. Interesting systems, effective at high methane conversions, are the mixed oxides of $\mathrm{Sr}$ and $\mathrm{Ce}$; and $\mathrm{Sr}, \mathrm{Ce}$, and $\mathrm{Yb}[43]$. The effectiveness of these systems suggests that benefits may be obtained from studies of other mixed metal oxides of alkaline earths.

$\mathrm{BaO}$ alone gives a high $\mathrm{C}_{2}$ selectivity at low partial pressures of oxygen $[23,25]$. When mixed with other alkaline earth oxides, it is an effective catalyst, but is less so in mixtures with $\mathrm{Si}, \mathrm{Al}$, or transition metal oxides [44]. Promotion of $\mathrm{BaCO}_{3}$ with alkali metals was found to have little effect on selectivity at high conversion [24]. The peroxide $\mathrm{BaO}_{2}$ supported on alumina decomposes to generate $\mathrm{O}_{2}$ at the surface, but this $\mathrm{O}_{2}$ does not appear to react with methane [45].

\section{Lanthanide and Actinide Metals/}

At low partial pressures of oxygen, conversion of methane to $\mathrm{C}_{2}$ is highly selective but slow over $\mathrm{M}_{2} \mathrm{O}_{3}(\mathrm{M}=\mathrm{Sc}, \mathrm{Y})$ [20]. At higher temperatures, over $\mathrm{Y}_{2} \mathrm{O}_{3} / \mathrm{SiO}_{2}$, small amounts of formaldehyde were also detected [46]. As described later, $\mathrm{Y}_{2} \mathrm{O}_{3}$-stabilized zirconia has been used as solid electrolyte for electrochemically controlled coupling reaction, but the yttrium is not considered to be the catalytically active species [47].

Of the oxides of the lanthanides, $\mathrm{M}_{x} \mathrm{O}_{y}, \mathrm{CeO}_{2}$ is unusual in that it catalyzes nonselective oxidation but not coupling [48-50]. Ce/ $\alpha-\mathrm{Al}_{2} \mathrm{O}_{3}$ is also ineffective [3]. However, the ion-conducting characteristics of $\mathrm{SrCeO}_{3}$ and $\mathrm{Ce}-\mathrm{Yb}$ mixed oxides impart effectiveness and selectivity for methane coupling at high conversion $(25-53 \%)$ [43]. The nonselec- 
tivity of cerium oxide, and related systems, has been attributed to the availability of more than one stable oxidation state [51].

The selectivity to $\mathrm{C}_{2}$ over $\mathrm{La}_{2} \mathrm{O}_{3}$ is very high at low partial pressures of oxygen, but decreases with increasing $\mathrm{O}_{2} / \mathrm{CH}_{4}$ ratio $[20,48,52,53]$. High selectivity to ethylene is attainable at low conversion. Ethane formed, or added to the feed stream, was converted both to ethylene and $\mathrm{CO}_{2}$ [52]. For $\mathrm{La}_{2} \mathrm{O}_{3} / \mathrm{SiO}_{2}$, a low selectivity to formaldehyde was achieved, but when promoted with $\mathrm{B}_{2} \mathrm{O}_{3}$, at low conversions, the selectivity to formaldehyde reached $100 \%$ [46]. A series of composite oxides $\mathrm{LaAlO}_{3}$, with $5-80 \% \mathrm{Al}$, has been studied [15, 53-55]. Under redox cycle conditions or cofeed of methane and air, good conversion and selectivity were attained. Lanthanide-manganese mixed oxides of Perovskite structure, doped with $\mathrm{Na}$ or $\mathrm{K}$, are also effective for methane conversion [56].

Promotion of $\mathrm{La}_{2} \mathrm{O}_{3}$ with alkali or, especially, alkaline earth metals improves selectivity to $\mathrm{C}_{2}[30,51,57]$. Over $1 \% \mathrm{Sr} / \mathrm{La}_{2} \mathrm{O}_{3}$, selectivity to $\mathrm{C}_{2+}$ of $77 \%$ is attainable. Substantial amounts of hydrogen as well as $\mathrm{CO}_{x}$ were formed and the relative amounts of $\mathrm{CO}, \mathrm{CO}_{2}$, and $\mathrm{H}_{2}$ were controlled by the water-gas shift equilibrium [51,57].

$\mathrm{La}, \mathrm{Ce}, \mathrm{Nd}$, and $\mathrm{Sm}$ are excellent promoters for " $\mathrm{Li} / \mathrm{MgO}$ " (vide supra), giving $C_{2}$ selectivities to $98.4 \%$ at significant conversion [26]. $\mathrm{Pr}$ is less selective. The use of lanthanide metals as promoters for a wide variety of three-component catalysts comprising a metal of Groups 8-11, a Group 6 metal oxide, and an alkaline earth oxide, supported on various oxide supports, has been claimed, but results for the lanthanidepromoted systems were not presented [58].

Whereas $\mathrm{Pr}_{2} \mathrm{O}_{3}[20,59]$ and $\mathrm{Pr}_{6} \mathrm{O}_{11}[60]$ are of modest effectiveness for coupling to $\mathrm{C}_{2}$, the latter promoted with an alkali metal is highly effective [60]. For the other lanthanide metals high selectivities can be attained, but normally at low conversion or rate [20,51, 59], except for $\mathrm{Sm}_{2} \mathrm{O}_{3}$. The basicity (or amphotericity) of $\mathrm{Sm}_{2} \mathrm{O}_{3}$ apparently makes it the most effective oxide of the lanthanide series [20, 48, 59, 61-64]. Promotion of $\mathrm{Sm}_{2} \mathrm{O}_{3}$ by lithium salts, especially $\mathrm{LiCl}$, further enhances the utility of the catalyst, but only at low pressures $[30,65]$. When $\mathrm{CO}_{2}$ was added to an air/methane feed over $\mathrm{Sm}_{2} \mathrm{O}_{3}$ the yield of $\mathrm{C}_{2}$ improved, with a slight reduction in selectivity to ethylene [33]. However, for the $\mathrm{Li}_{2} \mathrm{O}$-promoted system the yield was drastically reduced when $\mathrm{CO}_{2}$ was added, and for the $\mathrm{PbO}$-promoted system, yields of $\mathrm{C}_{2}$ were very poor [33]. Nonselective oxidation is favored over $\mathrm{Tb}_{4} \mathrm{O}_{7}$, which is capable of affording a large quantity of available oxygen $[66,67]$.

Although $\mathrm{Th} / \mathrm{SiO}_{2}$ was the first catalyst reported for the conversion 
of methane to $\mathrm{C}_{2}$ [19], the actinide series has been studied little. $\mathrm{ThO}_{2}$, $\mathrm{U}_{3} \mathrm{O}_{8}$, and $\mathrm{MoO}_{3} \cdot \mathrm{UO}_{2}$ are of some effect for partial oxidation [68]. For $\mathrm{Pd} / \mathrm{ThO}_{2}$, the selectivity to formaldehyde is improved when haloalkanes are present [69]. Under cyclic conditions $\mathrm{ThO}_{2}$ supported on $\mathrm{Al}_{2} \mathrm{O}_{3}$ or $\mathrm{SiO}_{2}$ is effective over a wide range of temperatures (673$973 \mathrm{~K}$ ) for conversion of methane to $\mathrm{C}_{2}$ [64], the latter being highly selective to ethylene at higher temperatures.

The promoted lanthanide oxides seem to be the most promising catalysts so far for methane coupling. Not only the activity and selectivity, but also the catalyst life is a very important asset for the coupling catalysts under the severe reaction conditions employed. Compounds other than "simple" oxides, stable at coupling conditions, are clearly a prospect. The use of composite oxides, other than $\mathrm{LaAlO}_{3}$, has not been deeply explored. The role of lanthanides in promoting " $\mathrm{Li} / \mathrm{MgO}$ " suggests their use as promoters for other systems. $\mathrm{As} \mathrm{LiCl}$ so distinctly enhanced the activity of $\mathrm{Sm}_{2} \mathrm{O}_{3}$ at low pressures, a search for additives effective at higher pressures would be worthwhile.

\section{Transition Metals}

With the most notable exception of oxides of manganese [70, 71], the oxides of the transition metals are normally effective alone only as catalysts for nonselective oxidation. However, when supported, or when present as composite materials, or when promoted, especially with alkali metal halides, significant activity for coupling of methane has been achieved. Alkali metal nitrates or hydroxides appear to be parallel but less effective promoters [72].

When $\mathrm{TiO}_{2}$ is the catalyst, either as anatase or rutile, little or no coupling activity is observed $[24,35,70]$. However, addition of $\mathrm{Li}$ as promoter improved the selectivity to $\mathrm{C}_{2}$, with optimum effectiveness at $16.2 \% \mathrm{Li}$ [73]. The most dramatic improvement occurred when $\mathrm{TiO}_{2}$ was promoted with $\mathrm{LiCl}$ : Selectivity to $\mathrm{C}_{2}$ was over $80 \%$, and predominantly to ethylene [35]. The formation of $\mathrm{C}_{2}$ has been correlated with the generation of $\mathrm{O}^{-}$holes, generated by UV irradiation of $\mathrm{TiO}_{2}$ [74].

The use of $\mathrm{TiO}_{2}$ as a support has received some attention, particularly for $\mathrm{PbO}$ (see section II.B.5.d). However, the use of catalysts comprising metals (or compounds) supported on $\mathrm{TiO}_{2}$ promoted with alkali metals has not been intensely studied [38, 41].

The few results using $\mathrm{ZrO}_{2}$ as catalyst or as support are similar to those observed for $\mathrm{TiO}_{2}[3,24,35,43,44,46,75]$. Work on promoted $\mathrm{ZrO}_{2}$ is essentially nonexistent. Considerable opportunities therefore 
exist, both for further work using $\mathrm{ZrO}_{2}$ promoted with alkali or alkaline earth metals and especially for use of $\mathrm{TiO}_{2}$ or $\mathrm{ZrO}_{2}$ promoted with $\mathrm{LiCl}$ and related systems as supports.

When admixed with other oxides, notably $\mathrm{SiO}_{2}$ or $\mathrm{MoO}_{3}, \mathrm{~V}_{2} \mathrm{O}_{5}$ is very effective for partial oxidation to $\mathrm{CH}_{2} \mathrm{O}$ and $\mathrm{CH}_{3} \mathrm{OH}$ [68]. $\mathrm{Nb}_{2} \mathrm{O}_{5}$ also affords $\mathrm{CH}_{2} \mathrm{O}$, but $\mathrm{Ta}_{2} \mathrm{O}_{5}$ affords $10-15 \% \mathrm{C}_{2}$ at low conversions [46]. Otherwise, supported vanadium catalysts are singularly ineffective for coupling $[3,6,76]$, and niobium and tantalum systems are virtually uninvestigated. $\mathrm{O}^{-}$holes generated in $\mathrm{V}_{2} \mathrm{O}_{5} / \mathrm{SiO}_{2}$ by $\gamma$-irradiation reacted with $\mathrm{CH}_{4}$ to generate mainly $\mathrm{CO}$, but when UV irradiation was used the main product was $\mathrm{C}_{2} \mathrm{H}_{6}$, with some $\mathrm{CH}_{2} \mathrm{O}$ [74]. By comparison with results for $\mathrm{TiO}_{2}$ (above), it would therefore be worthwhile to investigate the oxidation of methane over the Group 5 metal oxides promoted with alkali or alkaline earth metals, or used as supports.

Either $\mathrm{Cr}_{2} \mathrm{O}_{3}$ alone or promoted with $\mathrm{LiCl}$ gave only $\mathrm{CO}_{x}$ as products at high temperatures and oxygen/methane ratios [70], and low selectivity to $\mathrm{C}_{2}$ occurred with alkali metal nitrate promoted $\mathrm{Cr}_{2} \mathrm{O}_{3}$ [72]. However, at high pressures, low oxygen/methane ratios, and high space velocity, partial oxidation occurred at temperatures close to $650 \mathrm{~K}$ [68]. For $\mathrm{Cr}_{2} \mathrm{O}_{3}$ supported on $\mathrm{SiO}_{2}$ or $\mathrm{Al}_{2} \mathrm{O}_{3}$, high selectivity to $\mathrm{C}_{2}$ could be achieved in a cyclic mode $[3,64]$.

For $\mathrm{MO}_{3}(\mathrm{M}=\mathrm{Mo}, \mathrm{W})$, or heteropolyanions containing these metals, or admixes with oxides of $\mathrm{Al}, \mathrm{Cu}, \mathrm{Fe}, \mathrm{Si}, \mathrm{U}, \mathrm{V}$, or $\mathrm{Zn}$, for example, activity for nonselective oxidation or partial oxidation is observed, but no significant activity for coupling is shown $[3,6,68,77,78]$. In contrast, $\mathrm{PbMO}_{4}(\mathrm{M}=\mathrm{Cr}, \mathrm{Mo}, \mathrm{W})$ [25] and especially the layered oxychloride $\mathrm{PbBi}_{3} \mathrm{WO}_{8} \mathrm{Cl}[79]$ show significant coupling activity. Whether this coupling activity is due only to the presence of $\mathrm{Pb}$ and/or $\mathrm{Bi}$ is undetermined, but it indicates the possibility of rewarding effort in the study of similar low surface area composite oxides of Group 6 metals. Molecular orbital theoretical studies indicate potential application of $\mathrm{MoS}_{2}$ for methane activation [80].

Under cyclic conditions [7, 81] or low oxygen/methane ratio [35], $\mathrm{Mn}_{2} \mathrm{O}_{3}$ and $\mathrm{MnO}_{2}$ are effective for coupling, but at oxygen/methane ratios close to 0.5 , only total oxidation is observed [70]. However, promotion of $\mathrm{MnO}_{x}$ with $\mathrm{NaCl}$ [71] or $\mathrm{LiCl}$ [70] gave the $\mathrm{C}_{2+}$ selectivities up to $65.2 \%$ at $1023 \mathrm{~K}$ and for oxygen/methane ratios close to 0.5 . $\mathrm{LiCl}$ was especially effective as a promoter for generation of ethylene [70], but alkali metal nitrates gave only low selectivity to $C_{2}$ [72].

For $\mathrm{Mn}$ supported on $\mathrm{NaY}$ [82, 83], high-silica zeolites [82, 83], aluminas $[7,39,64,81]$, or on silica $[6,7,82]$, high selectivities to $C_{2+}$ 
were obtained at $673-1073 \mathrm{~K}$, especially when promoted with alkali metals [7, 81-84], and operated in cyclic mode. The most effective promoter appears to be $\mathrm{Na}[7,30,82,83]$, although other alkali or alkaline earth metals or lanthanum are very effective. The sodium may be introduced when the catalyst is prepared by impregnation of the support with $\mathrm{NaMnO}_{4}$ [85], or by sequential deposition of, for example, manganese acetate and a sodium salt. Of the Na salts used as promoters, $\mathrm{NaCl}$ and $\mathrm{NaBr}$ are by far the most effective [82]. The surface area of promoted $\mathrm{Mn} / \mathrm{SiO}_{2}$ decreased from $61 \mathrm{~m}^{2} / \mathrm{g}(0.22 \% \mathrm{Na})$ to $0.4 \mathrm{~m}^{2} / \mathrm{g}$ $(4.2 \% \mathrm{Na})$, and this is a factor in the observed improvement in $\mathrm{C}_{2+}$ selectivity from $53 \%$ to $92 \%$ [7]. Notably, $\mathrm{Na}_{4} \mathrm{P}_{2} \mathrm{O}_{7}$ is very effective as a promoter of activity, selectivity, and stability [7, 81, 84, 85]. Dual fluidized beds effectively exploit these catalysts [86].

Higher temperatures $(\sim 1200 \mathrm{~K})$ are required for the most effective use of $\mathrm{Mn} / \mathrm{SiO}_{2}$ promoted with $\mathrm{Na}_{4} \mathrm{P}_{2} \mathrm{O}_{7}$, or $\mathrm{Mn} / \mathrm{MgO}$, prepared by impregnation of $\mathrm{MgO}$ with $12.5 \% \mathrm{NaMnO}_{4}$, under cofeed conditions [85]. Optimum yields were obtained with $50 \%$ air $/ 50 \%$ methane feed, and catalyst longevity was demonstrated.

If, instead of $\mathrm{Mn} / \mathrm{SiO}_{2}$, composite oxides $\mathrm{MnSiO}_{x}, \mathrm{Mn}_{2} \mathrm{SiO}_{x}$, or $\mathrm{Mn}_{7} \mathrm{SiO}_{12}$ are used, modest selectivity to $\mathrm{C}_{2+}$ is again observed. For the same systems promoted with $\mathrm{Na}$, or $\mathrm{NaMnO}_{x}$, very high selectivity to $\mathrm{C}_{2}$ + was obtained, and the catalyst performance was stable over time [7]. Further, manganese silicate catalysts also operate effectively under cofeed conditions [87].

In the cyclic mode of operation, $\mathrm{Mn} / \mathrm{MgO}$ was found to be effective, with $\mathrm{CO}_{2}$ and $\mathrm{C}_{2} \mathrm{H}_{6}$ predominating at low conversions, but $\mathrm{C}_{2} \mathrm{H}_{4}$ and $\mathrm{C}_{3+}$ at high conversions [11]. $\mathrm{Na}_{2} \mathrm{MgSiO}_{4}$ is an effective promoter [12], and $\mathrm{Mg}_{6} \mathrm{MnO}_{8}$ has been identified in the catalyst and may be the effective component [12].

Molten salts are formed under oxidative coupling conditions (1072$1203 \mathrm{~K}$, oxygen $/$ methane $=50-90 \%$ ) using $\mathrm{MnSO}_{4} / \mathrm{Li}_{2} \mathrm{SO}_{4}, \mathrm{MnSO}_{4} /$ $\mathrm{Na}_{2} \mathrm{SO}_{4}, \mathrm{NaMnO}_{4} / \mathrm{Li}_{2} \mathrm{~B}_{10} \mathrm{O}_{16}, \mathrm{NaMnO}_{4} / \mathrm{Na}_{2} \mathrm{Si}_{2} \mathrm{O}_{5}, \mathrm{NaMnO}_{4} / \mathrm{Li}_{3} \mathrm{PO}_{4}$, or $\mathrm{NaMnO}_{4} / \mathrm{Na}_{2} \mathrm{~B}_{2} \mathrm{O}_{7}$ (each $1: 1$ ). Selectivity to $\mathrm{C}_{2}$ varied with both catalyst composition and methane conversion, from $13 \%$ to $57 \%$. The optimum catalyst was $\mathrm{MnSO}_{4} / \mathrm{Na}_{2} \mathrm{SO}_{4}$, operating at $1179 \mathrm{~K}$, for which $\mathrm{C}_{2}+$ selectivity was $57 \%$ at $24.5 \%$ methane conversion [88].

Similarly, $\mathrm{MnO}$ in a $\mathrm{LiPO}_{3} / \mathrm{KPO}_{3}$ eutectic gave very high $\mathrm{C}_{2}+$ selectivities at modest $(\sim 10 \%)$ conversions [88]. These results suggest that further work with molten salt systems and various catalysts would be beneficial.

Synthetic kentrolite, $\mathrm{Pb}_{2} \mathrm{Mn}_{2} \mathrm{Si}_{2} \mathrm{O}_{9}$ supported on $\mathrm{SiO}_{2}$ [89], and the 
perovskites $\mathrm{Ln}_{x} \mathrm{Na}_{1-x} \mathrm{MnO}_{3}(\mathrm{Ln}=\mathrm{La}, \mathrm{Sm}, \mathrm{Gd}, \mathrm{Ho} ; x=0.8,0.9)$ [56] are effective coupling catalysts.

No details of any catalyst system containing rhenium, ruthenium, or osmium are available.

For iron oxide, alone or promoted with $\mathrm{LiCl}$, no coupling activity was observed [70]. When $\mathrm{Fe}_{2} \mathrm{O}_{3}$ was promoted with alkali metal nitrates, the selectivity was low [72]. At lower temperatures $(\sim 700 \mathrm{~K})$ and low oxygen/methane ratios, low selectivity to methanol is found [68]. However, $\left(\mathrm{MoO}_{3}\right)_{2} \mathrm{Fe}_{2} \mathrm{O}_{3}$ is highly effective for partial oxidation [68]. At very low temperatures $(293-313 \mathrm{~K})$ methane is converted over $\mathrm{Pt} /$ graphite in acidified aqueous $\mathrm{Fe}_{2}\left(\mathrm{SO}_{4}\right)_{3}$ to methanol with very high selectivity $(92 \%)$ [90]. However, mixtures of methane and oxygen passed over acidified $\mathrm{Fe}_{2}\left(\mathrm{SO}_{4}\right)_{3}$ gave only $\mathrm{CO}_{2}$ [91].

At high temperatures over $\mathrm{Co}_{3} \mathrm{O}_{4}$, no $\mathrm{C}_{2}$ hydrocarbons were formed [76], but at lower temperatures $(<845 \mathrm{~K})$, modest yields of $\mathrm{C}_{2}[76]$ or methanol [68] were obtained. Significant yields of $C_{2}$ were observed when $\mathrm{Co}_{3} \mathrm{O}_{4}$ was promoted with $\mathrm{LiCl}$ [70], and lesser yields of $\mathrm{C}_{2}$ with other alkali metal promoters [72]. At low conversions over $\mathrm{CoO} / \mathrm{Al}_{2} \mathrm{O}_{3}$ or $\mathrm{Co} / \mathrm{SiO}_{2}$ high selectivity to $\mathrm{C}_{2}$ is obtained at low temperatures (673$973 \mathrm{~K}$ ) in cyclic operation [64].

At low partial pressures of methane and oxygen (2:1), nonselective oxidation occurred over unpromoted $\mathrm{NiO}$, but high selectivity to $\mathrm{C}_{2}$ was achieved by promotion with $\mathrm{LiCl}, \mathrm{Li}_{2} \mathrm{O}, \mathrm{Li}_{2} \mathrm{CO}_{3}$ [72], or alkali metal nitrates [72]. $\mathrm{LiCl}$ is especially effective in promoting formation of ethylene [70]. At high partial pressure $\left(\mathrm{CH}_{4}+\mathrm{O}_{2}=84 \mathrm{kPa}\right)$ the selectivity to $\mathrm{CO}_{2}$ rises to $51 \%$, and $\mathrm{C}_{3}, \mathrm{C}_{4}$, and aromatic hydrocarbons are also formed in low amounts.

Under cyclic conditions, at low temperatures ( $733 \mathrm{~K}$ ) and low conversions, high selectivity to ethane, but not ethylene, was achieved over $\mathrm{NiO} / \mathrm{Al}_{2} \mathrm{O}_{3}$ or $\mathrm{NiO} / \mathrm{SiO}_{2}$ [64].

Either Pd or Pt systems, on various supports, catalyze only nonselective oxidation [3, 91, 92]. However, a solution of $\mathrm{Pd}(\mathrm{OAc})_{2}$ in fluoroacetic acid, at high pressure, gave high yields $(60 \%)$ of methyl fluoroacetate [93].

Clearly there is considerable untapped potential in the use of transition metal systems, or composite systems, for oxidative coupling. Promotion of transition metal oxides with alkali, or alkaline earth, metal oxides, halides, and oxyanions such as phosphate has already shown considerable effect. Similar promotion of composite oxides will also extend the selection of available systems. At present, systems containing manganese appear to be the most likely to attain application, but, 
with suitable promoters, other transition metals may well prove highly useful.

\section{Posttransition Elements}

\section{a. Group 11 Elements $(\mathrm{Cu}, \mathrm{Ag}, \mathrm{Au})$}

The volatility of gold precludes use of the bulk metal or supported crystallites under oxidative coupling conditions.

Although ineffective alone, when $\mathrm{CuO}$ was promoted with $\mathrm{LiCl}$ [70] or alkali metal nitrates [72], coupling activity was observed, but the effectiveness was less than that of, for example, Mn, Ni, or $\mathrm{Zn}$. Curiously, when $\mathrm{LiCl}$ is the promoter, the only hydrocarbon product is ethylene, suggesting that subsequent dehydrogenation of any ethane formed is very efficiently catalyzed. When $\mathrm{CuO}$ supported on silica was used, no ethylene was produced, but selectivities for ethane up to $70 \%$ were achieved under cyclic conditions, at $773 \mathrm{~K}$ and at low conversions [64]. Alumina-supported $\mathrm{CuO}$ is less effective.

Silver catalysts, $\mathrm{Ag}, \mathrm{Ag}_{2} \mathrm{O}$, or supported $\mathrm{Ag}$, are ineffective for coupling in cyclic or cofeed mode but have activity for partial oxidation $[3,68,94,98]$. In contrast, the layered oxychloride $\mathrm{AgBi}_{3} \mathrm{O}_{4} \mathrm{Cl}_{2}$ gives high selectivity to $\mathrm{C}_{2}$, especially ethylene, at low pressures and $23.7 \%$ conversion [79].

These data suggest that promotion of $\mathrm{Ag}_{2} \mathrm{O}$ by chlorides, especially $\mathrm{LiCl}$ or $\mathrm{NaCl}$, would confer coupling activity. Use of copper or silver salts, promoted with chlorides, may be of interest.

\section{b. Group 12 Elements $(\mathrm{Zn}, \mathrm{Cd}, \mathrm{Hg})$}

Mercury is so volatile, and its compounds frequently so unstable, that its use in high-temperature processes is unlikely. No such catalyst has been used in oxidative coupling. However, at high methane/oxygen ratios, $\mathrm{CdO}$ was found to be an effective coupling catalyst [20]. At low conversions $\mathrm{CdO} / \mathrm{Al}_{2} \mathrm{O}_{3}$ is also effective [75, 95]. Good selectivities to $\mathrm{C}_{2}$, especially ethylene, are obtained over $\mathrm{CdBiO}_{2} \mathrm{Cl}$ [79].

Promotion of $\mathrm{ZnO}$ with $\mathrm{LiCl}$ [70] or $\mathrm{Li}_{2} \mathrm{O}$ [29, 36, 66, 96] confers coupling activity, with good selectivity to ethylene. Otherwise low activity for either coupling or partial oxidation is observed $[20,24,35$, $68,70] . \mathrm{ZnO}$ is a nonbasic semiconductor, unlike $\mathrm{MgO}$, which is a basic insulator. However, the Li-doped oxides are much more similar in both electronic and basic properties, and so are also similar in catalytic 
properties [96]. With $\mathrm{MoO}_{3} \cdot \mathrm{ZnO}$ partial oxidation is effected at high pressures, but at low conversion [68].

c. Group 13 Elements (Al, Ga, In, Tl)

The primary use of $\mathrm{Al}_{2} \mathrm{O}_{3}$, alone or as an admix, is as a support for other catalyst systems. It does not have significant activity for coupling in cyclic or cofeed mode, under normal coupling conditions. At higher temperatures, in the absence or low partial pressure of oxygen, low conversions to hydrocarbon mixes $\left(\mathrm{C}_{2}-\mathrm{C}_{7}\right)$ are effected, with high selectivity to ethylene over $\alpha-\mathrm{Al}_{2} \mathrm{O}_{3}[6]$ or $\mathrm{Li}_{2} \mathrm{O} / \mathrm{Al}_{2} \mathrm{O}_{3}$ [39]. Activity under cofeed conditions is also effected by adding $\mathrm{Na}$ or $\mathrm{Ca}$ as promoter [39].

The system $\mathrm{Al}_{x} \mathrm{La}_{2-x} \mathrm{O}_{3}$ has been found effective for coupling of methane at atmospheric pressure [53]. Optimum rate and selectivity to $\mathrm{C}_{2}$ were each at $10 \mathrm{~mol} \% \mathrm{Al}(x=0.2)$.

In the absence of an oxidant, Ga/ZSM-5 (Na- or H-form) is effective at a pressure of $7 \mathrm{~atm}$ for coupling methane to aromatics with a selectivity of approximately $50 \%$ [97]. In the presence of oxygen $C_{2}$ hydrocarbons were observed only at very high temperatures [46]. Similarly, In and $\mathrm{Tl}$, as oxides or supported catalysts, are essentially effective only for nonselective oxidation $[3,20,38]$. When $\mathrm{In} / \mathrm{SiO}_{2}$ is promoted with alkali metals or their phosphates the $\mathrm{C}_{2+}$ selectivities to $52.2 \%$ were obtained at $7.3 \%$ conversion $[6,81]$. Use has been made of dual reactors to exploit this activity [86].

\section{d. Group 14 Elements (Si, Ge, Sn, Pb)}

Silica is essentially inactive for oxidative coupling up to $1223 \mathrm{~K} \mathrm{[3].}$ For temperatures lower than approximately $1075 \mathrm{~K}$, stainless steel has low activity, but at higher temperatures, activity becomes significant. Thus, at temperatures over $1075 \mathrm{~K}$, quartz reactors are preferred. For alumina-silica composites, the activity and selectivity are dependent upon both acidity and added counterion [25]. For $\mathrm{SiO}_{2}-\mathrm{P}_{2} \mathrm{O}_{5}$ composites, above $973 \mathrm{~K} \mathrm{C}_{2}$ hydrocarbons predominated over $\mathrm{CH}_{2} \mathrm{O}$, but below $973 \mathrm{~K}$, selectivity to $\mathrm{CH}_{2} \mathrm{O}$ increased to a maximum close to $60 \%$ [46]. $\gamma$ Irradiation of $\mathrm{P} / \mathrm{SiO}_{2}$ generates $\mathrm{O}^{-}$holes, which can then interact with methane to generate methyl radicals [74].

Germanium has been little studied, although effectiveness has been demonstrated for $\mathrm{GeO}_{2}$ at low partial pressures of oxygen [20,59], and for $\mathrm{Ge} / \mathrm{SiO}_{2}$ under redox cycle conditions [6]. Although claimed in a patent [81], and used in a dual reactor system [86], no details of the 
effectiveness of $\mathrm{Ge} / \mathrm{SiO}_{2}$ promoted with alkali metals or their phosphates have been given.

The use of tin-containing catalysts has been more widely studied. Even at low partial pressures of oxygen under a range of conditions $\mathrm{SnO}_{2}[20,59,99,100]$ and mixtures of $\mathrm{SnO}_{2}$ with $\mathrm{Bi}_{2} \mathrm{O}_{3}$ or $\mathrm{Sb}_{2} \mathrm{O}_{3}[99$, 100] are not effective for coupling, giving mainly $\mathrm{CO}_{x}$. Similarly, under cofeed conditions, $\mathrm{SnO}_{2}$ supported on $\alpha$ - or $\gamma$-alumina is a relatively poor oxidative coupling catalyst, even when promoted with $\mathrm{Na}$ or $\mathrm{K}$ $[38,101]$. However, in cyclic mode, high $\mathrm{C}_{2}$ selectivity is obtained, at low conversions, but the effectiveness is highly dependent upon the support. For $\mathrm{Sn} / \alpha-\mathrm{Al}_{2} \mathrm{O}_{3}$, very low selectivity to $\mathrm{C}_{2}$ was observed $(0.4 \%$ at $1073 \mathrm{~K}$ ), with none detected below $973 \mathrm{~K}$ [3]. Over a different alumina, selectivity as high as $90 \%$ can be achieved at $973 \mathrm{~K}$, but this selectivity decreases as the residence time increases [64]. For $10 \%$ $\mathrm{Sn} / \mathrm{Al}_{2} \mathrm{O}_{3}$ promoted with $5 \% \mathrm{Na}, \mathrm{C}_{2}$ selectivity of $32 \%$ was observed [81]. For $\mathrm{Sn} / \mathrm{SiO}_{2}$, prepared by various techniques, high selectivity to $\mathrm{C}_{2}$ is achieved under cyclic conditions $[6,64,81]$. Promotion with $\mathrm{Na}$ improved the $\mathrm{C}_{2}$ selectivity on $10 \% \mathrm{Sn} / \mathrm{SiO}_{2}$ from $37 \%$ to $85 \%$, at conversions less than 5\% [81]. Selectivities as high as $90 \%$ have been reported for low conversions [64]. Use of dual-bed reactors to exploit $\mathrm{Sn} / \mathrm{SiO}_{2}$ has been claimed [86].

Composite oxides of $\mathrm{Sn}$ have also been examined. $\mathrm{Bi}_{2} \mathrm{Sn}_{2} \mathrm{O}_{7}$ has been found more effective than $8 \% \mathrm{Bi} / \mathrm{Al}_{2} \mathrm{O}_{3}$ [39]. Selectivities to $\mathrm{C}_{2}$ as high as $40 \%$, at low conversions, were reported for $\mathrm{Sn}-\mathrm{SbO}[75$, 95]. The system $\mathrm{Sn}_{2} \mathrm{P}_{2} \mathrm{O}_{7} / \mathrm{SiO}_{2}$ was reported to be effective at high pressures $(1-100 \mathrm{~atm})$ and a range of temperatures $(673-1473 \mathrm{~K})$, but no details of performance were given [102].

Lead is one of the most intensely studied of all elements for use as oxidative coupling catalysts. The oxides of lead in oxidation state higher than $\mathrm{Pb}$ (II) are unstable at $1 \mathrm{~atm}$ and temperatures close to $1000 \mathrm{~K}$. Thus the "reducible" lead oxide expected to be present under coupling conditions is $\mathrm{PbO}$. This oxide is considerably more effective than $\mathrm{SnO}$, or even the unpromoted lanthanide or transition metal oxides, when used alone $[20,25,59] . \mathrm{C}_{2}$ selectivities as high as $63 \%$ were reported, for low conversions [25]. For this system, reduction of the oxide to the metal occurs, and oxygen reoxidizes the metal crystallites to bulk oxide, for example [6]. Although lead is not particularly volatile $(1 \mathrm{~mm}$ at $1243 \mathrm{~K})$ - nor is $\mathrm{PbO}(1 \mathrm{~mm}$ at $1218 \mathrm{~K})$-some volatilization of lead occurs under coupling conditions [66]. It is therefore advantageous to avoid formation of metallic lead and use of $\mathrm{PbO}$.

When the catalyst is a complex of lead instead, the oxygen is con- 
tained in a counterion, and problems associated with volatility can be reduced. For a reducible oxyanion, formation of water may involve oxygen obtained from this counterion. For an irreducible oxyanion, oxygen used for the reaction must be either that adsorbed or from the gas phase. It is therefore very interesting that high selectivities to $\mathrm{C}_{2+}$ are obtained over $\mathrm{PbSO}_{4}(63 \%)$ and $\mathrm{Pb}_{3}\left(\mathrm{PO}_{4}\right)_{2}(51 \%)$, and lower values for $\mathrm{PbMO}_{4}(\mathrm{M}=\mathrm{Cr}$, Mo, W) [25, 102]. Unfortunately, the superior selectivity to both $\mathrm{C}_{2}$ and $\mathrm{CH}_{2} \mathrm{O}$ reported for $\mathrm{PbMoO}_{4}$ may be associated with the much lower conversion compared with $\mathrm{PbCrO}_{4}$ and $\mathrm{PbWO}_{4}$ [25]. The synthetic kentrolite $\mathrm{Pb}_{2} \mathrm{Mn}_{2} \mathrm{Si}_{2} \mathrm{O}_{9}$ contains both $\mathrm{Pb}$ and $\mathrm{Mn}$ as potentially active centers; it is as yet undetermined whether both, either, or the combination is responsible for the effectiveness of this material [89]. Similarly, the highly effective layered oxides $\mathrm{PbBiO}_{2} \mathrm{Cl}$ and $\mathrm{PbBi}_{3} \mathrm{WO}_{8} \mathrm{Cl}$ contain multiple potential redox centers [79].

Lead, usually assumed to be present as crystallites of $\mathrm{PbO}$, has been used extensively when supported on $\alpha^{-}, \beta^{\prime \prime}$ - or $\gamma$-alumina $[3,6,14,35$, $37-39,42,52,53,64,75,81,86,96,97,99,101-105]$. The effectiveness, in terms of rate, conversion, and selectivity to $\mathrm{C}_{2+}$, varies considerably with the absolute and relative partial pressures of methane and oxygen, temperature (673-1273 K), and presence of additives. When supported, the type of support [103] and the loading of lead [14, 37] also influence the effectiveness. An advantage also accrues from the use of alkali metal salts as promoters $[37-39,53,101]$, but a detailed study of the efficacy of such promoters for $\mathrm{Pb} / \mathrm{Al}_{2} \mathrm{O}_{3}$ remains a pending task.

Surprisingly, at $1023 \mathrm{~K}$ under cyclic conditions over $\mathrm{PbO} / \gamma-\mathrm{Al}_{2} \mathrm{O}_{3}$ mixed with silica, nonselective oxidation was considerably more favorable than under cofeed conditions [52]. However, at 673-973 K under cyclic conditions, the $\mathrm{C}_{2}$ selectivities up to $90 \%$ were obtained [64].

For lead supported on alumina-silica, poor selectivities to $\mathrm{C}_{2+}$ are obtained, unless the catalyst is promoted with $\mathrm{Na}[14,37,103,105]$. For $\mathrm{NaY}$ exchanged with $\mathrm{Pb}(5.1 \%)$, using $\mathrm{N}_{2} \mathrm{O}$ as oxidant, optimum selectivity and yield were obtained at temperatures close to $823 \mathrm{~K}$; lower temperatures gave lower conversions and higher temperatures gave more $\mathrm{CO}_{x}$ products [101]. With air, the same catalysts produce predominantly $\mathrm{CO}_{x}$.

The activity of $\mathrm{PbO} / \mathrm{SiO}_{2}$ depends on both loading and surface area $[6,14,37,53,64,81,86,97,99,103,105]$, and decreases drastically with time on stream $[103,105]$. The use of alkali metals as promoters has been claimed, but detailed results are not available $[81,86]$. 
When the support is a basic oxide, $\mathrm{BeO}[103,105], \mathrm{MgO}[35,42$, $52,103,105], \mathrm{CaO}$ or $\mathrm{CaCO}_{3}[35,103,105], \mathrm{SrO}$ or $\mathrm{SrCO}_{3}[103,105]$, or $\mathrm{BaO}$ or $\mathrm{BaCO}_{3}[103,105]$, or when a mixed oxide such as $\mathrm{PbO}-$ $\mathrm{MgO}$ is used [36], the selectivity to $\mathrm{CO}_{x}$ is lowest for the most basic oxides, and the selectivity to ethylene is highest. For $\mathrm{PbO}-\mathrm{MgO}$ the catalyst operates under cyclic or cofeed conditions, but productivity is much greater for the latter. Selectivities as high as $80 \%$ to $\mathrm{C}_{2+}$ are attainable at low oxygen/methane ratios [36].

Whereas $20 \% \mathrm{PbO} / \mathrm{La}_{2} \mathrm{O}_{3}[103,105]$ affords $\mathrm{C}_{2}$ selectivity similar to, for example, $20 \% \mathrm{PbO} / \mathrm{SrO}, 20 \% \mathrm{PbO} / \mathrm{Sm}_{2} \mathrm{O}_{3}$ gives essentially no yield of $\mathrm{C}_{2}$, either in the presence or in the absence of $\mathrm{CO}_{2}$ [35]. For $20 \% \mathrm{PbO}$ supported on various transition metal and posttransition metal oxides or $\mathrm{SiC}$, the selectivity to $\mathrm{C}_{2}$ varies considerably, even at low conversions $[97,99,103,105]$. The best selectivity was obtained on $\mathrm{TiO}_{2}[14,103,105], \mathrm{ZrO}_{2}[103,105], \mathrm{ZnO}[103,105], \mathrm{SnO}_{2}$ [103, 105], and $\mathrm{Bi}_{2} \mathrm{O}_{3}[97,99]$. For $\mathrm{Nb}_{2} \mathrm{O}_{3}$ or $\mathrm{CuO}$ as supports, poor selectivities were obtained $[103,105]$. With $\mathrm{SiC}$ as support, selectivity to ethane was $100 \%$, but at $0.1 \%$ conversion $[103,105]$. If instead of supporting $\mathrm{PbO}$, a mixture of $\mathrm{PbO}(31 \%), \mathrm{Bi}_{2} \mathrm{O}_{3}(54 \%)$, and $\mathrm{Sb}_{2} \mathrm{O}_{3}(14 \%)$ is used, poor selectivity to $\mathrm{C}_{2}$ is observed unless the partial pressure of oxygen is kept low [97, 99].

Lead-based catalyst systems present one of the most promising prospects for application for oxidative coupling of methane. One problem is the volatility of lead. Much is expected to be learned from a detailed study of the effects of promoters upon supported lead catalysts, and on nonvolatile lead salts such as $\mathrm{PbSO}_{4}, \mathrm{~Pb}_{3}\left(\mathrm{PO}_{4}\right)_{2}$, and those of other oxyanions. Of particular interest will be the effect of various alkali and alkaline earth halides, hydroxides, oxide, or carbonates.

\section{e. Group 15 Elements (As, Sb, Bi)}

The only report detailing use of arsenic concerns $\mathrm{As}_{2} \mathrm{O}_{3} / \mathrm{SiO}_{2}$, which gives low yield of $\mathrm{C}_{2}$ but $40 \%$ selectivity to $\mathrm{CH}_{2} \mathrm{O}$ at low conversion [46]. The role of arsenate ion, or arsenates of metals such as manganese or lead, has not been studied in detail. As phosphates of these metals have proved effective (vide supra), the use of such arsenates represents a reasonable prospect.

Antimony affords the prospect of both one- and two-electron redox reactions, as the oxide systems of $\mathrm{Sb}(\mathrm{V}), \mathrm{Sb}(\mathrm{IV})$, and $\mathrm{Sb}$ (III) are readily 
attainable. The system $\mathrm{Sb}_{2}\left(\mathrm{PO}_{4}\right)$ has also been used, alone or supported on $\mathrm{SiO}_{2}$ or $\mathrm{MgO}$ [102]. For the mixed oxides $\mathrm{Sb}_{2} \mathrm{O}_{3} / \mathrm{SnO}_{2}$ or $\mathrm{Sb}_{2} \mathrm{O}_{3} /$ $\mathrm{PbO} / \mathrm{Bi}_{2} \mathrm{O}_{3}$ the activity differed from the sum of activities of the components $[97,99]$. Whether the results were due to modification by promotion or sequential reactions on different components has not been determined. Poor yields were obtained except at high methane/oxygen ratio and slow flow rates $[97,99]$. For $\mathrm{Sb}$ or $\mathrm{Sb}_{2} \mathrm{O}_{3}$ supported on $\mathrm{SiO}_{2}$, good selectivity to $\mathrm{C}_{2}+$ was obtained, but only in the cyclic mode of operation at low conversions [3,6]. Under cofeed conditions low selectivity to $\mathrm{C}_{2}$ was obtained, and $\mathrm{CH}_{2} \mathrm{O}(\sim 60 \%)$ was the favored product, again at low conversions [46].

Using $\mathrm{Sb}_{2} \mathrm{O}_{4}$ on $\mathrm{Al}_{2} \mathrm{O}_{3}$, promoted with $\mathrm{K}_{2} \mathrm{CO}_{3}$, no higher hydrocarbons were formed [38]. In contrast, potassium-promoted $\mathrm{Sb}_{2} \mathrm{O}_{4} / \mathrm{SiO}_{2}$ was effective for either oxidative coupling to higher hydrocarbons or complete oxidation, depending on reaction conditions and precise catalyst composition [106]. Results for coupling using the $\mathrm{SiO}_{2}$-supported catalyst were superior to those for bulk antimony oxide, with or without potassium promotion [106].

Although use of $\mathrm{Sb}_{2} \mathrm{PO}_{4}$ has been claimed for a range of conditions (1-100 atm; 673-1473 K), no details of the results are given [102]. However, for $\mathrm{SbPO}_{4} / \mathrm{SiO}_{2}, \mathrm{Sb}_{2} \mathrm{PO}_{4} / \mathrm{SiO}_{2}$, and $\mathrm{Sb}_{2} \mathrm{PO}_{4} / \mathrm{MgO}$, examples of results are reported for operation at temperatures between $1023 \mathrm{~K}$ and $1108 \mathrm{~K}$, and with conversions of $17.3-21 \%$ and $29-42 \% \mathrm{C}_{2}+$ selectivity [102]. Thus such systems are a reasonable prospect for use. Even better results may be obtained if they are modified with promoters, and if no volatility of the catalyst is experienced.

Bismuth systems are also promising oxidative coupling catalysts. Although $\mathrm{Bi}_{2} \mathrm{O}_{3}$ is ineffective at high partial pressures of oxygen, even when promoted with $\mathrm{KOH} \mathrm{[38],} \mathrm{at} \mathrm{high} \mathrm{methane/oxygen} \mathrm{ratios} \mathrm{excel-}$ lent selectivity to $\mathrm{C}_{2}$ is obtained [20,59]. A molecular orbital study of the interaction of methane or propene with the surface of $\alpha-\mathrm{Bi}_{2} \mathrm{O}_{3}$ has provided insight into the activation process [107]. Mixtures of $\mathrm{Bi}_{2} \mathrm{O}_{3}$ with other oxides, $\mathrm{SnO}_{2}$ [97, 99], $\mathrm{PbO}[97,99]$, or $\mathrm{B}_{2} \mathrm{O}_{3}$ and $\mathrm{SiO}_{2}$ [46], are not good coupling catalysts, except under conditions of long residence time and high methane/oxygen ratios. However, the composite oxide $\mathrm{Bi}_{2} \mathrm{Sn}_{2} \mathrm{O}_{7}$ is reasonably effective at the low temperature of $781 \mathrm{~K}[39]$.

Under cofeed conditions, $\mathrm{Bi} / \mathrm{Al}_{2} \mathrm{O}_{3}$ is not very effective [39], but under cyclic conditions, $\mathrm{C}_{2}$ selectivities up to $85 \%$ were obtained at low conversions $[3,64]$. When $\mathrm{Bi} / \gamma-\mathrm{Al}_{2} \mathrm{O}_{3}$ was promoted with $\mathrm{K}_{2} \mathrm{CO}_{3}$ 
[38], or $\mathrm{K}_{2} \mathrm{O}$ and $\mathrm{P}_{2} \mathrm{O}_{5}$ [41], significant improvement in selectivity to $\mathrm{C}_{2}$ was observed under cofeed conditions. Optimum loading was found to be $5-10 \% \mathrm{Bi}$ and close to $9 \% \mathrm{~K}_{2} \mathrm{CO}_{3}$ with little benefit at higher concentrations [38].

In the cyclic mode of operation over $\mathrm{Bi}_{2} \mathrm{O}_{3} / \mathrm{SiO}_{2}$, high selectivity to $\mathrm{C}_{2}$ has also been observed [6, 64]; promotion with alkali metals has been claimed, but no details have been given [81]. Use of dual-bed reactors to exploit these catalysts has been reported [86]. Under cofeed conditions, low yields of $\mathrm{C}_{2}$ were obtained, even when promoted with $\mathrm{KOH}$ or $\mathrm{K}_{2} \mathrm{CO}_{3}[38,46]$. However, for methane/oxygen = 8, promotion with $\mathrm{K}_{2} \mathrm{O}$ and $\mathrm{P}_{2} \mathrm{O}_{5}$ gave an effective catalyst [41].

For $\mathrm{Bi}_{2} \mathrm{O}_{3} / \mathrm{MgO}$ similar results were found. The unpromoted catalyst was not very selective, but when promoted with $\mathrm{K}_{2} \mathrm{O}$ and $\mathrm{P}_{2} \mathrm{O}_{5}$, and using oxygen or $\mathrm{N}_{2} \mathrm{O}$ as oxidant, high selectivities to $\mathrm{C}_{2}$ were obtained [41]. When the support was $\mathrm{TiO}_{2}$, even the catalysts promoted with $\mathrm{Cs}_{2} \mathrm{CO}_{3}[38]$ or $\mathrm{K}_{2} \mathrm{O}$ and $\mathrm{P}_{2} \mathrm{O}_{5}$ [41] were not effective.

An interesting system is the use of oxygen pumped through yttriastabilized zirconia with $\mathrm{Bi}_{2} \mathrm{O}_{3} / \mathrm{Ag}$ electrode [47]. As the surface oxygen is increased by increasing the oxygen flow with applied voltage, the selectivity to $\mathrm{C}_{2}$ decreases. However, selectivities as high as $70 \% \mathrm{C}_{2}$ were observed at low oxygen pumping rates [47] (see section V.C for further information).

\section{Evaluation of Catalytic Activity}

\section{Problems in Comparison}

A review of the literature on methane coupling in an attempt to compare the activity of catalysts is a difficult and sometimes frustrating process. This is mainly due to the differences in the reaction conditions employed by various investigators. Among the reaction conditions, W/ $F$ particularly seems to have a great effect on the $\mathrm{C}_{2}$ yield. For example, Otsuka and Komatsu [108] observed that the $S T Y$ of $\mathrm{C}_{2}$ increased from 146 to $828 \mu \mathrm{mol} \cdot \mathrm{sec}^{-1} \cdot \mathrm{g}^{-1}$ when $W / F$ was changed from 0.012 to $0.0008 \mathrm{~g} \cdot \mathrm{sec} \cdot \mathrm{mL}^{-1}$ on a $\mathrm{Sm}_{2} \mathrm{O}_{3}$ catalyst at $1023 \mathrm{~K}$. Also, some papers report results with gaseous hourly space velocity (GHSV) but do not give the weight of catalyst whereas others report results with $W / F$ without giving the volume of the catalyst bed. A quantitative comparison between those reports is impossible. 
Other factors must also be considered in comparing the activity of catalysts. Campbell et al. [48] reported that a hydrothermal pretreatment of the lanthanide oxides not only changed the surface areas but also changed their activities for the formation of methyl radicals. In the same paper, the authors found that $\mathrm{Er}_{2} \mathrm{O}_{3}$ obtained from one source showed only $20 \%$ of the activity per unit surface area of the same oxide supplied from another source. Ali Emesh and Amenomiya [38] reported that the preparation methods of $\mathrm{K}_{2} \mathrm{CO}$-promoted $\mathrm{Bi}_{2} \mathrm{O}_{3} / \mathrm{Al}_{2} \mathrm{O}_{3}$ catalyst made large differences in the yield of $\mathrm{C}_{2}$. The initial composition of catalysts may not represent that of the working catalysts. Kimble and Kolts $[109,110]$ observed that a $8.0 \mathrm{wt} \% \mathrm{Li} / \mathrm{CaO}$ catalyst lost lithium during calcination down to $4.2 \%$ and finally to $1.0 \%$ after it was used in the reaction. Similarly the levels of lithium in $\mathrm{CaO}$ catalysts with other initial $\mathrm{Li}$ contents were all reduced to about $1 \%$ after use. As a result, all catalysts showed similar conversion and selectivity independent of the initial concentration of Li. Supported lead catalysts also lose the metal as already mentioned. Roos et al. [66] observed that 28 wt $\% \mathrm{~Pb} / \mathrm{Al}_{2} \mathrm{O}_{3}$ lost $\mathrm{Pb}$ to $6 \mathrm{wt} \%$ during the coupling reaction over $300 \mathrm{~h}$ at $1073 \mathrm{~K}$.

Because of these difficulties, results obtained with a series of catalysts under the same reaction conditions are very useful in evaluating the catalytic performance. Ito et al. [111] reported a series of $\mathrm{MgO}$ catalysts with various concentrations of $\mathrm{Li}$. $\mathrm{BeO}$ catalysts promoted with various concentrations of $\mathrm{Li}$ were compared by Matsuura et al. [112]. Moriyama et al. [113] examined $\mathrm{MgO}$ promoted by alkali, alkaline earth metals, and other metals at various concentrations.

The activity and selectivity of the rare earth metal oxides for methane coupling were measured by Otsuka et al. $[20,59]$ and compared with those of the oxides of low-melting metals. Some of the rare earth metal oxides were also tested with nitrous oxide and methane [119]. Recently, Campbell et al. [48] also compared the catalytic performance of lanthanide oxides and found some differences between their results and those of Otsuka et al. [20,59]. However, they reported that the pretreatment of the catalysts and their source could make differences in the catalytic activity as already described. Yingli et al. [114] tested some of the lanthanide oxides promoted by lithium whereas the effect of alkali and other metal promoters on $\mathrm{La}_{2} \mathrm{O}_{3}$ was examined by DeBoy and Hicks [115]. Otsuka et al. [116] investigated $\mathrm{Sm}_{2} \mathrm{O}_{3}$ catalyst promoted by various alkali metals.

As mentioned earlier, Keller and Bhasin [3] first screened a number of metal oxides supported on $\alpha$-alumina for the oxidative coupling of 
methane by using a cyclic mode of reaction. In a similar redox cyclic mode, Sofranko et al. [6] tested silica-supported and unsupported metal oxides. Silica- and alumina-supported metal oxides were also examined for the coupling reaction by Doval et al. [64]. Hinsen et al. [14] studied $\mathrm{PbO}$ catalysts with various support materials and different concentrations of the metal. Asami et al. [103] investigated the effect of support for $\mathrm{PbO}$ over a total of 23 support materials including $\mathrm{MgO}$. The oxides of low-melting metals of groups 13,14 , and 15 in the periodic table were compared by supporting them on $\mathrm{K}_{2} \mathrm{CO}_{3}$-promoted alumina by Ali Emesh and Amenomiya [38]. Various alkali promoters on $\mathrm{ZnO}$ were compared by Matsuura et al. [117], and the oxides of the first transition metals promoted by $\mathrm{LiCl}$ were reported by Otsuka et al. [70]. Nagamoto et al. [118] studied a series of perovskite $\left(\mathrm{ABO}_{3}\right)$ catalysts with various alkaline earth metals as $\mathrm{A}$ and with $\mathrm{Ti}, \mathrm{Zr}$, and $\mathrm{Ce}$ as $\mathrm{B}$.

In the reports described above, a series of similar type of catalysts is compared, for example, by changing promoter and support or varying their concentrations. Recently Carreiro et al. [23], Burch et al. [30], and Yingli et al. [114] compared the catalytic performance of different types of catalysts under the same reaction conditions. The results should give useful information for the evaluation of catalysts.

\section{Comparison of Activity}

The space time yields $(S T Y)$ reported for the oxidative coupling of methane are listed in Table 1 together with the reaction conditions. All results were obtained by cofeeding the reactants and the space time yield listed is the largest $S T Y$ reported in each paper. The $S T Y$ in Table 1 has been expressed as $S T Y$ per gram of catalyst since this unit has been used most often in the published reports. $S T Y / \mathrm{m}^{2}$ reported in some papers was converted to $S T Y / g$ as long as the surface area was available. Also when possible, $W / F$ was calculated from the flow data given. $W / F$ is believed to be better for the comparison of the catalytic performance than the volumetric space velocity when very small amounts of catalysts were used. Although the results are listed in order of $S T Y$, Table 1 should not be considered to represent the order of the catalytic performance. The reaction conditions are not the same and many other factors affect the catalytic activity, as already pointed out. Large ratios of $\mathrm{CH}_{4} / \mathrm{O}_{2}$ were used in all experiments so that the conversion of oxygen was usually quite high, sometimes exceeding $90 \%$. This makes it more difficult to compare the real activity of the catalyst. 
TABLE I

Comparison of Catalytic Performance

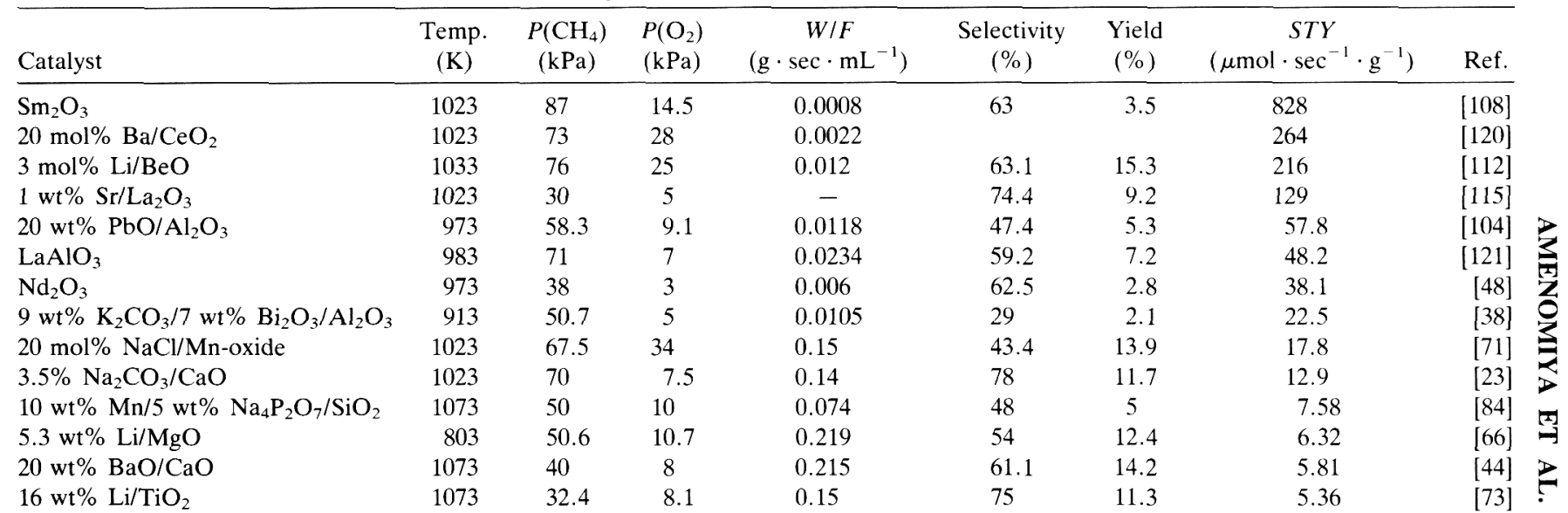




\section{MECHANISM OF REACTION}

\section{A. Activation of Methane}

Activation of methane over solid catalysts may be less of a problem than is often suggested. It is well known that methane and other hydrocarbons are dissociatively adsorbed on the surfaces of many metals and metal oxides [63, 126-153] and adsorbed $\mathrm{CH}_{x}$ radicals seem to be important intermediates. Carboanions are involved in similar reactions at metal oxides, especially insulator materials such as alumina [154, 155] and magnesium oxide [154-156]. The catalytic activity of oxide catalysts can be assessed from the bond energy of oxygen to the surface of the catalyst as a good correlation has been found between the activation energies of the reaction of homomolecular oxygen exchange, methane and hydrogen oxidation, and the oxygen bond energy on the oxide surface [157-159]. The real problem lies in inducing the adsorbed species to react to give selectively the desired products with a reasonable conversion rate.

\section{Alkali and Alkaline Earth Metal Oxides}

At the high temperatures employed for the methane coupling reaction, homogeneous reactions could take place without the catalyst. According to a detailed study by Yates and Zlotin [125], the homogeneous coupling of methane and formation of $\mathrm{CO}_{x}$ in an empty quartz reactor were substantial at temperatures higher than $900 \mathrm{~K}$, but at lower temperatures the homogeneous reactions were much less compared with those which occurred in the presence of $\mathrm{MgO}$ and $\mathrm{Li} / \mathrm{MgO}$ catalysts. Apparently, the methane coupling reaction involves the catalyst, at least at lower temperatures. The breakage of the $\mathrm{C}-\mathrm{H}$ bond will be the first step in any methane activation reaction except probably for the activation by superacid. Fang and Yeh suggested in their early report of methane conversion [19] that methyl radicals would be formed in the gas phase by the reaction of methane with the catalyst followed by their homogeneous dimerization.

The formation of methyl radicals in the gas phase was confirmed experimentally by Lunsford and his co-workers [17, 160] with $\mathrm{MgO}$ and $\mathrm{Li} / \mathrm{MgO}$ catalysts by trapping the radicals in a solid argon matrix for EPR spectroscopy. They also detected $\left[\mathrm{Li}^{+} \mathrm{O}^{-}\right]$centers in lithiumdoped magnesia by EPR when it was heated in air at $773 \mathrm{~K}$ or higher and quenched in liquid nitrogen $[17,111]$. The amount of methyl radi- 
cals formed and that of $\left[\mathrm{Li}^{+} \mathrm{O}^{-}\right]$centers detected showed a good parallelism when the concentration of lithium was varied [17]. It was also found that the radical concentration and the conversion of methane responded similarly to the variation of oxygen pressure [111]. From these facts, Lunsford and his co-workers [111] proposed that the activation of methane takes place by abstracting hydrogen atoms on the $\left[\mathrm{Li}^{+} \mathrm{O}^{-}\right]$centers. These centers are formed by oxygen vacant holes ([ ]) trapped at $\mathrm{O}^{2-}$ ions adjacent to $\mathrm{Li}^{+}$ions as follows:

$$
\begin{aligned}
& 2 \mathrm{Li}^{+} \mathrm{O}^{2-}+\left[\mathrm{]}+\frac{1}{2} \mathrm{O}_{2} \rightleftarrows 2 \mathrm{Li}^{+} \mathrm{O}^{-}+\mathrm{O}^{2-}\right. \\
& \mathrm{Li}^{+} \mathrm{O}^{-}+\mathrm{CH}_{4} \rightarrow \mathrm{Li}^{+} \mathrm{OH}^{-}+\mathrm{CH}_{3} .
\end{aligned}
$$

The $\left[\mathrm{Li}^{+} \mathrm{O}^{-}\right]$centers are regenerated by

$$
\begin{aligned}
& 2 \mathrm{Li}^{+} \mathrm{OH}^{-} \rightarrow \mathrm{Li}^{+} \mathrm{O}^{2-}+\mathrm{Li}^{+}[]+\mathrm{H}_{2} \mathrm{O} \\
& \mathrm{Li}^{+} \mathrm{O}^{2-}+\mathrm{Li}^{+}[]+\frac{1}{2} \mathrm{O}_{2} \rightarrow 2 \mathrm{Li}^{+} \mathrm{O}^{-}
\end{aligned}
$$

or

$$
\begin{aligned}
& 2 \mathrm{Li}^{+} \mathrm{OH}^{-} \rightarrow \mathrm{Li}^{+} \mathrm{O}^{-}+\mathrm{Li}^{+}\left[\mathrm{e}^{-}\right]+\mathrm{H}_{2} \mathrm{O} \\
& \mathrm{Li}^{+}\left[\mathrm{e}^{-}\right]+\frac{1}{2} \mathrm{O}_{2} \rightarrow \mathrm{Li}^{+} \mathrm{O}^{-}
\end{aligned}
$$

Thus the surface $\mathrm{O}^{-}$species are responsible for the activation of methane. A recent work of molecular orbital theory by Mehandru et al. [153] also indicates that the abstraction of $\mathrm{H}$ from methane by $\mathrm{O}^{-}$ species on the surface of stoichiometric $\mathrm{MgO}$ has much lower activation energy than that by $\mathrm{O}^{2-}$ species. Driscoll et al. [17] found the $\mathrm{O}^{-}$ species by .EPR on $\mathrm{MgO}$ as well as on $\mathrm{Li} / \mathrm{MgO}$. However, the $\mathrm{O}^{-}$ species found on $\mathrm{MgO}$ were very stable and did not react with methane, suggesting that these species were not on the surface [17].

Lunsford and his co-workers extended their studies to catalysts promoted by other alkali metals (M) and found $\left[\mathrm{M}^{+} \mathrm{O}^{-}\right]$centers with $\mathrm{Li} / \mathrm{MgO}, \mathrm{Li} / \mathrm{CaO}$ [123], Na/CaO [123, 124], and $\mathrm{Li} / \mathrm{ZnO}$ [96]. However, they could not detect $\left[\mathrm{K}^{+} \mathrm{O}^{-}\right]$species on $\mathrm{K} / \mathrm{CaO}$ catalyst in spite of the fact that it was active for methane coupling [123]. No $\left[\mathrm{M}^{+} \mathrm{O}^{-}\right]$ centers were found on $\mathrm{Na} / \mathrm{MgO}$ and $\mathrm{K} / \mathrm{MgO}$, which showed poor yields of $\mathrm{C}_{2}$ hydrocarbons [123]. These two catalysts, however, have been 
reported to be active for methane coupling by Moriyama et al. [113] and Kimble and Kolts [109, 110].

Other oxygen species have also been claimed to be active for methane activation. Results obtained with $\mathrm{BaO}_{2}$ by Sinev et al. [161] and with $\mathrm{Na}_{2} \mathrm{O}_{2}, \mathrm{BaO}_{2}$, and $\mathrm{SrO}_{2}$ by Otsuka et al. [162] indicated that the peroxide ions $\left(\mathrm{O}_{2}^{2-}\right)$ were active for the coupling reaction. The latter report also showed that the superoxide ions $\left(\mathrm{O}_{2}^{-}\right)$did not activate methane. Fujimoto et al. [28] suggested that an adsorbed oxygen instead of lattice oxygen reacted with methane on alkali earth halide/alkali earth oxide catalysts.

\section{Rare Earth Metal Oxides}

Although lanthanum oxide produced a much larger amount of $\mathrm{CH}_{3}$. radicals in the gas phase than did the $\mathrm{Li} / \mathrm{MgO}$ catalyst [52], the $\mathrm{O}^{-}$ species have not yet been detected by EPR on the oxides of the rare earth elements. Lin et al. [52] observed $\mathrm{O}_{2}^{-}$ions when a sample of $\mathrm{La}_{2} \mathrm{O}_{3}$ was quenched from $923 \mathrm{~K}$ to liquid nitrogen in the presence of oxygen but not $\mathrm{O}^{-}$species. In contrast to $\mathrm{Li} / \mathrm{MgO}, \mathrm{CH}_{3} \cdot$ radicals were formed in the gas phase with $\mathrm{La}_{2} \mathrm{O}_{3}$ only when oxygen was present in the reactant stream. From these observations they suggested that the active species on this oxide were transient, namely, the $\mathrm{O}^{-}$species were formed from $\mathrm{O}_{2}^{-}$during the reaction. Wang and Lunsford [163] further suggested that the superoxide ions are in equilibrium with the surface peroxide ions and oxygen:

$$
\mathrm{O}_{2}+\mathrm{O}_{2}^{2-} \rightleftarrows 2 \mathrm{O}_{2}^{-}
$$

Otsuka and Nakajima [61] also could not detect $\mathrm{O}^{-}$ions in samarium oxide by EPR. Without detection of the species, Otsuka et al. [59] assumed that $\left[\mathrm{Sm}^{3+} \mathrm{O}^{-}\right]$species were active centers on $\mathrm{Sm}_{2} \mathrm{O}_{3}$. In another work on $\mathrm{Sm}_{2} \mathrm{O}_{3}$ [164], Otsuka and Jinno concluded from the observed kinetics of methane coupling that adsorbed diatomic oxygen instead of monatomic oxygen were the active species. This seems to agree with Lunsford et al.[52]; that is, the transient $\mathrm{O}^{-}$species are formed from $\mathrm{O}_{2}^{-}$. In any case, an important difference between the rare earth metal oxide and alkali/alkaline earth oxide catalysts is that the active oxygen species on the rare earth oxides are a sorbed form of oxygen whereas those in the latter catalysts are a part of the lattice, as pointed out by Lunsford and his co-workers [52]. 


\section{Other Oxides}

The process of activation of methane and the oxygen species responsible for the activation on other metal oxides are not clear. Driscoll and Lunsford [160] found by using the technique of radical trapping in a solid argon matrix that $\mathrm{Bi}_{2} \mathrm{O}_{3}, \alpha-\mathrm{Bi}_{2} \mathrm{O}_{3}-\mathrm{MoO}_{3}$, and $\mathrm{PbO}$ produced none or much fewer $\mathrm{CH}_{3}$. radicals in a stream of methane at $748 \mathrm{~K}$ compared with $\mathrm{MgO}$ and $\mathrm{Li} / \mathrm{MgO}$. However, these oxides were active for the formation of allyl radicals from propylene, and it was suggested that a hydrogen atom was abstracted by lattice $\mathrm{O}^{2-}$ ions in sites of low coordination [160]. Sinev et al. [104] also suggested that $\mathrm{O}^{2-}$ ions with reduced coordination could be responsible for the methane coupling reaction on a $\mathrm{PbO} / \mathrm{Al}_{2} \mathrm{O}_{3}$ catalyst. Suleimanov et al. [42] studied $\mathrm{PbO} / \mathrm{MgO}$ catalysts by EPR and found that a paramagnetic center due to $\left[\mathrm{PbO}_{4}\right]^{-}$increased noticeably upon heating at $1023 \mathrm{~K}$, and that these centers disappeared when the catalyst was contacted with methane at $1023-1073 \mathrm{~K}$. They further observed that the methane conversion was correlated to the concentration of the centers.

By using a lead mirror, Jones et al. [7] observed the formation of free radicals in the gas phase, most likely methyl radicals, on a sodiumpromoted manganese/silica catalyst.

\section{B. Reaction Mechanism}

When Ito and Lunsford [18] first reported that lithium-doped magnesia was an efficient catalyst for methane coupling, they assumed the formation of $\mathrm{CH}_{3}$. radicals on the surface $\left[\mathrm{Li}^{+} \mathrm{O}^{-}\right]$centers and subsequent dimerization of the radicals in the gas phase. As already mentioned, Lunsford and his co-workers showed that the amount of methyl radicals formed varied in parallel with the concentration of the $\left[\mathrm{Li}^{+} \mathrm{O}^{-}\right]$ centers [17]. Further, they [165] measured the concentration of $\mathrm{CH}_{3}$. radicals trapped directly from the atmospheric coupling reaction on $\mathrm{Li} / \mathrm{MgO}$ and indeed demonstrated that the rate of decay of the radicals was of second order for their concentration, as shown n Fig. 2.

Here we follow the mechanism of the methane coupling proposed for $\mathrm{Li} / \mathrm{MgO}$ and $\mathrm{Na} / \mathrm{CaO}$ catalysts by Lunsford and his co-workers $[111,124]$. Subsequent to Eqs. (3)-(8):

$$
2 \mathrm{CH}_{3} \cdot \rightarrow \mathrm{C}_{2} \mathrm{H}_{6}
$$




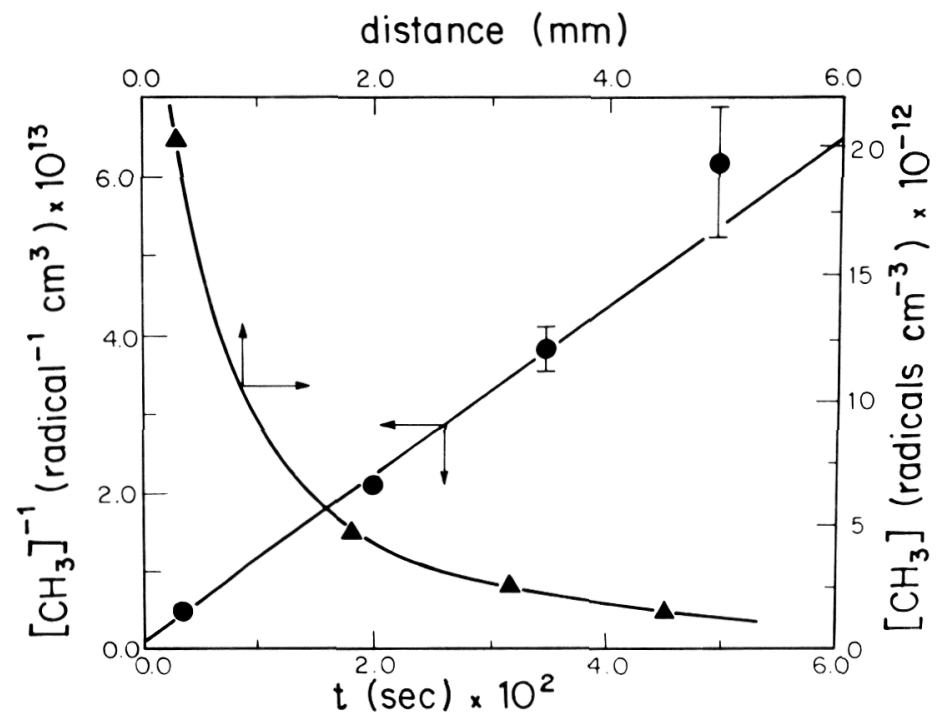

FIG. 2. Concentration of $\mathrm{CH}_{3}$. radicals as a function of distance from catalyst bed $(\boldsymbol{\Delta})$, and the plot of $\left[\mathrm{CH}_{3} \cdot\right]^{-1}$ versus time $(\boldsymbol{O})$. Catalyst $7 \mathrm{wt} \%$ $\mathrm{Li} / \mathrm{MgO}$, temperature $943 \mathrm{~K}$. Reproduced with permission from J. Am. Chem. Soc., 109, 7900 (1987).

The methyl radicals also produce $\mathrm{CO}_{x}$ through a series of chain reactions in the gas phase:

$$
\begin{aligned}
& \mathrm{CH}_{3} \cdot+\mathrm{O}_{2} \rightleftarrows \mathrm{CH}_{3} \mathrm{O}_{2} \cdot \\
& \mathrm{CH}_{3} \mathrm{O}_{2} \cdot+\mathrm{C}_{2} \mathrm{H}_{6} \rightarrow \mathrm{CH}_{3} \mathrm{O}_{2} \mathrm{H}+\mathrm{C}_{2} \mathrm{H}_{5} \cdot \\
& 2 \mathrm{CH}_{3} \mathrm{O}_{2} \cdot \rightarrow \mathrm{CH}_{2} \mathrm{O}+\mathrm{CH}_{3} \mathrm{OH}+\mathrm{O}_{2} \rightarrow \mathrm{CO}, \mathrm{CO}_{2} \\
& \mathrm{CH}_{3} \mathrm{O}_{2} \mathrm{H} \rightarrow \mathrm{CH}_{3} \mathrm{O} \cdot+\mathrm{OH} \cdot \\
& \mathrm{CH}_{3} \mathrm{O} \cdot+\mathrm{CH}_{4} \rightarrow \mathrm{CH}_{3} \mathrm{OH}+\mathrm{CH}_{3} \cdot \\
& \mathrm{OH} \cdot+\mathrm{CH}_{4} \rightarrow \mathrm{CH}_{3} \cdot+\mathrm{H}_{2} \mathrm{O}
\end{aligned}
$$

or on the surface:

$$
\mathrm{CH}_{3} \cdot+\mathrm{O}^{2-}(\text { surface }) \rightarrow \mathrm{CH}_{3} \mathrm{O}^{-}+\mathrm{e}^{-}
$$


$\mathrm{CH}_{3} \mathrm{O}^{-} \rightarrow \mathrm{CH}_{3} \mathrm{OH}, \mathrm{CH}_{2} \mathrm{O} \rightarrow \mathrm{CO}, \mathrm{CO}_{2}$

Ethane produced by the coupling reaction further reacts to form ethylene either on the surface:

$$
\begin{aligned}
& \mathrm{C}_{2} \mathrm{H}_{6}+\left[\mathrm{M}^{+} \mathrm{O}^{-}\right] \rightarrow \mathrm{C}_{2} \mathrm{H}_{5} \cdot+\left[\mathrm{M}^{+} \mathrm{OH}^{-}\right]_{s} \\
& \mathrm{C}_{2} \mathrm{H}_{5} \cdot+\mathrm{O}^{2-} \rightarrow \mathrm{C}_{2} \mathrm{H}_{5} \mathrm{O}^{-}+\mathrm{e}^{-} \\
& \mathrm{C}_{2} \mathrm{H}_{5} \mathrm{O}^{-} \rightarrow \mathrm{C}_{2} \mathrm{H}_{4}+\mathrm{OH}^{-}
\end{aligned}
$$

or in the gas phase through Eqs. (12), (22), (23), and (24):

$$
\begin{aligned}
& \mathrm{CH}_{3} \cdot+\mathrm{C}_{2} \mathrm{H}_{6} \rightarrow \mathrm{CH}_{4}+\mathrm{C}_{2} \mathrm{H}_{5} \cdot \\
& \mathrm{C}_{2} \mathrm{H}_{5} \cdot \rightarrow \mathrm{C}_{2} \mathrm{H}_{4}+\mathrm{H} \cdot \\
& \mathrm{C}_{2} \mathrm{H}_{5} \cdot+\mathrm{O}_{2} \rightarrow \mathrm{C}_{2} \mathrm{H}_{4}+\mathrm{HO}_{2} .
\end{aligned}
$$

The foregoing mechanism has been summarized by Lin et al. [124] in a scheme shown in Fig. 3.

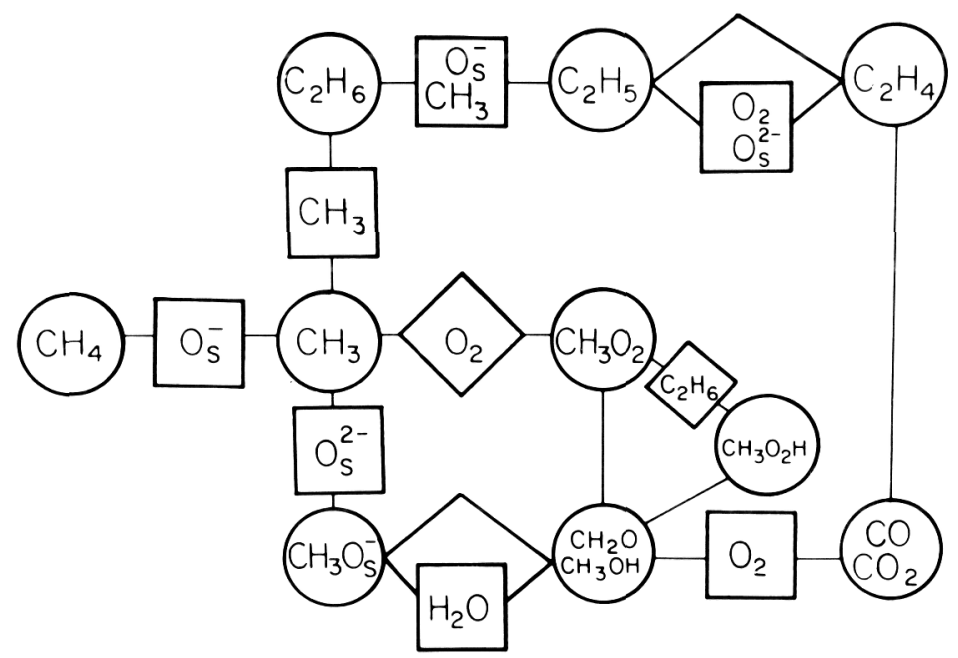

FIG. 3. Reaction scheme of the oxidative coupling of methane. Reproduced from Ref. 124 with permission of Journal of Catalysis. 
The major features of the above mechanism are: $(a)$ methyl radicals are formed catalytically and dimerize in the gas phase producing ethane; (b) the formations of ethane and $\mathrm{CO}_{x}$ are parallel reactions; (c) ethylene is formed from ethane as a secondary product; and $(d)$ the formations of $\mathrm{CO}_{x}$ and ethylene both take place heterogeneously and/or homogeneously. Most of the results of the methane coupling obtained on various catalysts have been explained by a similar mechanism although the details of the mechanisms are not always the same $[6,13,16,52,57$, $59,61,96,103,164]$. Sofranko et al. [6] observed that the hydrocarbon distribution was remarkably similar in the products obtained with various supported metal catalysts and with an empty reactor. From this they suggested that methane activation on the surface is followed by gas phase reactions which are responsible for carbon chain building. In a study of the coupling reaction on $\mathrm{Li} / \mathrm{MgO}$ with a mixture of $\mathrm{CH}_{4}$, $\mathrm{CD}_{4}$ and $\mathrm{O}_{2}$, Nelson et al. [166] found that the main $\mathrm{C}_{2}$ products were $\mathrm{C}_{2} \mathrm{H}_{6}, \mathrm{CH}_{3} \mathrm{CD}_{3}, \mathrm{C}_{2} \mathrm{D}_{6}, \mathrm{C}_{2} \mathrm{H}_{4}, \mathrm{CD}_{2} \mathrm{CH}_{2}$, and $\mathrm{C}_{2} \mathrm{D}_{4}$ without significant hydrogen exchange between $\mathrm{CH}_{4}$ and $\mathrm{CD}_{4}$. They interpreted the results as the confirmation of the fact that the coupling of methyl radicals and the dehydrogenation of ethane both proceeded in the gas phase. As the authors pointed out, however, the lack of significant exchange of hydrogen between $\mathrm{CH}_{4}$ and $\mathrm{CD}_{4}$ at these high temperatures is surprising since $\mathrm{MgO}$ is known to be active for the exchange reactions of $\mathrm{CH}_{4} / \mathrm{CD}_{4}[155,167]$. This might be a result of a fast consumption of the abstracted hydrogen in the presence of oxygen. If this is the case, the isotopic distribution of ethanes observed above does not allow us to conclude whether the coupling reaction proceeds in the gas phase or on the surface.

Other mechanisms have also been proposed for the formation of ethane and other parts of the reaction. Lunsford and his co-workers [52] suggested the possible involvement of carbene $\left(\mathrm{CH}_{2}\right)$ for the formation of ethylene, although carbene was not detected by argon matrix isolation. Based on the fact that the concentration of $\mathrm{CH}_{3}$. radicals in the gas phase is very low and that the $\mathrm{O}^{-}$species are not found on some catalysts active for methane coupling, Martin and Mirodatos [168, 169] proposed carbene as the intermediate for the formation of ethane on $\mathrm{Li} / \mathrm{MgO}$ :

$$
\begin{aligned}
& \mathrm{CH}_{4}+\mathrm{O}^{2-} \rightarrow \mathrm{CH}_{3}^{-}+\mathrm{OH}^{-} \\
& \mathrm{Li}^{+}+\mathrm{CH}_{3} \rightarrow \mathrm{Li}^{+} \mathrm{H}^{-} \mathrm{CH}_{2} . \\
& \mathrm{CH}_{2}+\mathrm{CH}_{4} \rightarrow \mathrm{C}_{2} \mathrm{H}_{6}
\end{aligned}
$$


They estimated the amount of carbene in the gas phase from cyclopropane formed on the addition of ethylene. However, Nelson et al. [166] pointed out that the carbene mechanism would not be the major route of ethane formation because of the lack of significant amount of $\mathrm{C}_{2} \mathrm{H}_{2} \mathrm{D}_{4}$ in the ethanes produced in their experiments with $\mathrm{CH}_{4}+\mathrm{CD}_{4}$ as described above.

The catalytic formation of ethane by the dissociative adsorption of methane was proposed on K-promoted $\mathrm{Bi}_{2} \mathrm{O}_{3} / \mathrm{Al}_{2} \mathrm{O}_{3}$ by Ali Emesh and Amenomiya [38] and on $\mathrm{Li} / \mathrm{BeO}$ by Doi et al. [29]. Asami et al. [170] also claimed that the dimerization of methyl radicals on a $\mathrm{PbO} / \mathrm{MgO}$ catalyst took place primarily on the surface. Based on the reactivity of

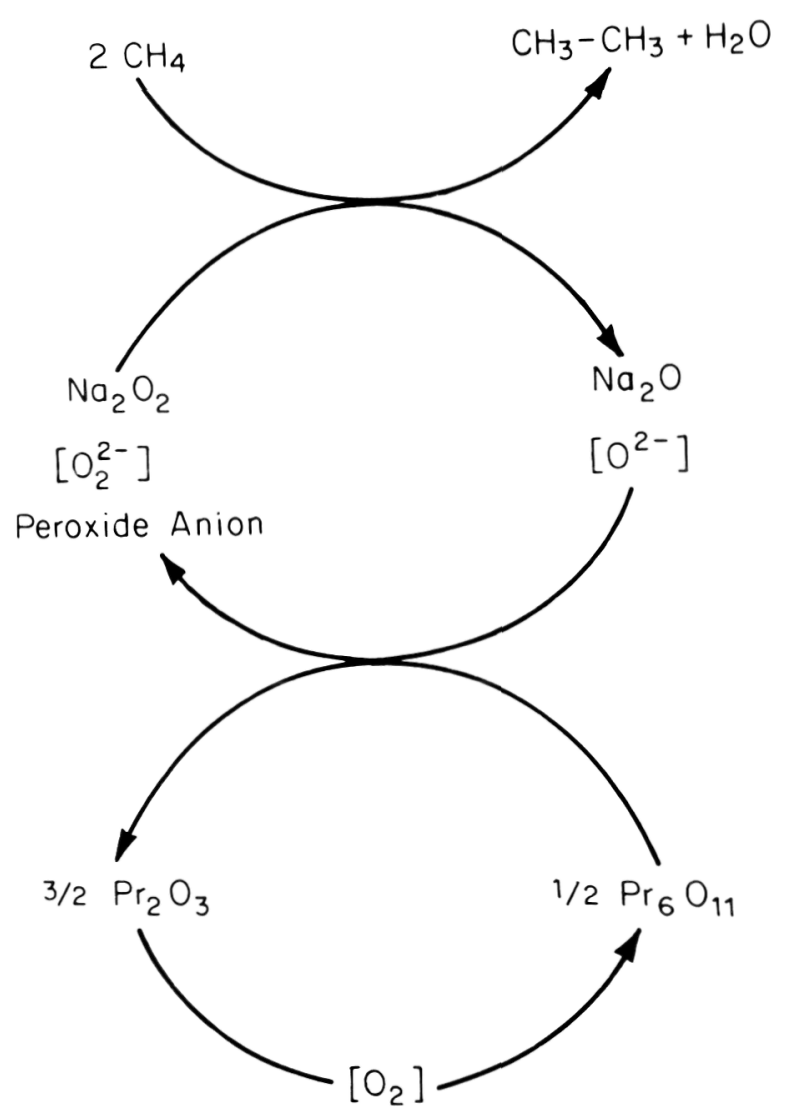

FIG. 4. Reaction scheme for an $\mathrm{Na} / \mathrm{Pr}_{6} \mathrm{O}_{11}$ catalyst. Reproduced from Ref. 8 with permission of Journal of Catalysis. 
the peroxide anion $\left(\mathrm{O}_{2}^{2-}\right)$, reported by Otsuka et al. [162], Gaffney et al. [8] recently proposed a mechanism for methane coupling on $\mathrm{Na} / \mathrm{Pr}_{2} \mathrm{O}_{3}$, as depicted in Fig. 4. Here, $\mathrm{Na}_{2} \mathrm{O}$ is oxidized back to $\mathrm{Na}_{2} \mathrm{O}_{2}$ by oxygen supplied from praseodymium oxide, which in turn is reoxidized by $\mathrm{O}_{2}$ in the gas phase.

Hutchings et al. [171] concluded that ethylene and ethane were both primary products on $\mathrm{Li} / \mathrm{MgO}$. This conclusion could be controversial [172], and one might conclude differently if the ratio of $\mathrm{C}_{2} \mathrm{H}_{4} / \mathrm{C}_{2} \mathrm{H}_{6}$, instead of individual selectivities, was plotted against the contact time. From a comparison of oxidants, they also concluded that the $\mathrm{O}$ - species led to $\mathrm{CO}_{x}$ whereas the $\mathrm{O}^{-}$species were responsible for the $\mathrm{C}_{2}$ formation [171]. At high temperatures, however, $\mathrm{O}^{-}$was thought by the same authors [94] to contribute also to the formation of $\mathrm{CO}_{x}$. With the aid of TPD, Tagawa and Imai [55] revealed two kinds of oxygen species adsorbed on $\mathrm{LaAlO}_{3}$, and found that the $\mathrm{C}_{2}$ hydrocarbons were formed by strongly adsorbed oxygen, while the weakly adsorbed or gaseous oxygen was responsible for $\mathrm{CO}_{x}$. Gaffney et al. [8] thought that $\mathrm{CO}_{x}$ was formed on $\mathrm{Na} / \mathrm{Pr}_{2} \mathrm{O}_{3}$ predominantly on the surface via allylic oxidation of olefins. Asami et al. $[170,173]$ concluded that on $\mathrm{PbO} / \mathrm{MgO}$, $\mathrm{CO}_{x}$ was formed by reaction between methane and oxygen adsorbed on $\mathrm{PbO}$.

Temperatures used for the oxidative coupling of methane are quite high so that many authors observed or assumed that the water-gas shift reaction is in equilibrium among $\mathrm{CO}, \mathrm{CO}_{2}, \mathrm{H}_{2}$, and $\mathrm{H}_{2} \mathrm{O}[33,57,80$, 96]. Imai et al. [15] also suggested that the steam-reforming reaction of methane took place on $\mathrm{LaAlO}_{3}$ at these temperatures.

\section{Kinetics}

It is difficult to obtain kinetic equations experimentally for the methane coupling reaction mainly because of the high conversion of oxygen. While Otsuka et al. [164] experimentally determined the rate of total methane conversion on a samarium oxide catalyst as a function of the pressures of the reactants, several other authors established kinetic models based on mechanisms similar to that described in section III.B. The methane conversion and the $C_{2}$ selectivity were then derived from these equations by taking the rate constants of homogeneous reactions from published values and determining the rate constants of heterogeneous reactions which best fit the experimental data. The derivation of these kinetic expressions was reported for $\mathrm{Li} / \mathrm{MgO}$ by Kimble and Kolts [109], for $\mathrm{Mn} / \mathrm{MgO}$ by Labinger and Ott [11], for $\mathrm{Li} / \mathrm{MgO}$ by 
TABLE 2

Reaction Orders

\begin{tabular}{|c|c|c|c|c|c|c|c|c|}
\hline \multirow[b]{2}{*}{ Catalyst } & \multirow[b]{2}{*}{ Temp (K) } & \multicolumn{2}{|c|}{$\mathrm{CH}_{4} \rightarrow \mathrm{C}_{2}$} & \multicolumn{2}{|c|}{$\mathrm{CH}_{4} \rightarrow \mathrm{CO}_{x}$} & \multicolumn{2}{|c|}{$\mathrm{C}_{2} \mathrm{H}_{6} \rightarrow \mathrm{C}_{2} \mathrm{H}_{4}$} & \multirow[b]{2}{*}{ Ref. } \\
\hline & & $m$ & $o$ & $m$ & $o$ & $e$ & $o$ & \\
\hline $\mathrm{Li} / \mathrm{MgO}$ & $900-1050$ & $\begin{array}{l}0.75 \\
(169)\end{array}$ & $-0.2-0.1$ & $\begin{array}{c}-0.1 \\
(90-118)\end{array}$ & 0.8 & $\begin{array}{c}0.4 \\
(140-250)\end{array}$ & -0.05 & {$[169]$} \\
\hline $\mathrm{Li} / \mathrm{BeO}$ & 953 & $\begin{array}{c}1.0 \\
(246)\end{array}$ & $0.3-0.5$ & $\begin{array}{c}0 \\
(103)\end{array}$ & 1.0 & $\begin{array}{c}0.5 \\
(127)\end{array}$ & 0.5 & {$[29]$} \\
\hline $\mathrm{LaAlO}_{3}$ & $983^{a}$ & $0.9-1.0$ & $0.5-1.2$ & $0.1-0.7$ & $1.4-1.7$ & & & {$[55]$} \\
\hline $\mathrm{LaAlO}_{3}$ & $983^{b}$ & $1.7-1.9$ & $-0.8-0.7$ & $0.7-0.9$ & $0.5-1.2$ & & & {$[55]$} \\
\hline $\mathrm{PbO} / \mathrm{Al}_{2} \mathrm{O}_{3}$ & 1013 & $\begin{array}{l}0.8 \\
(99)\end{array}$ & 1.1 & $\begin{array}{l}0.4 \\
(51)\end{array}$ & 1.5 & $\begin{array}{l}0.8 \\
(6)\end{array}$ & 1.6 & {$[14]$} \\
\hline $\mathrm{PbO} / \mathrm{Al}_{2} \mathrm{O}_{3}$ & $953-1073$ & 1.07 & 1.4 & $0.6-1.0$ & $2.0-0.34$ & & & {$[23]$} \\
\hline $\mathrm{K} / \mathrm{Sb}_{2} \mathrm{O}_{4}$ & $1023-1073$ & $\begin{array}{l}0.6 \\
(259)\end{array}$ & 0.2 & $\begin{array}{c}0.1 \\
(96)\end{array}$ & 0.8 & & & {$[16]$} \\
\hline $\mathrm{Sb}_{2} \mathrm{O}_{4}$ & $1023-1073$ & $\begin{array}{c}0.9 \\
(234)\end{array}$ & 0.5 & $\begin{array}{l}0.4 \\
(95)\end{array}$ & 0.8 & & & {$[16]$} \\
\hline $\mathrm{K} / \mathrm{Bi}_{2} \mathrm{O}_{3} / \mathrm{Al}_{2} \mathrm{O}_{3}$ & 823 & 2 & 1 & 0.3 & 1 & 1 & 2.5 & {$[38]$} \\
\hline $\mathrm{PbO} / \mathrm{MgO}$ & 1023 & $\begin{array}{c}0.9 \\
(210)\end{array}$ & 0 & $\begin{array}{c}0.4 \\
(108)\end{array}$ & 0.7 & 1 & 0 & {$[173]$} \\
\hline
\end{tabular}

Note. Rate $=k P\left(\mathrm{CH}_{4}\right)^{m} \cdot P\left(\mathrm{O}_{2}\right)^{o}$ or Rate $=k P\left(\mathrm{C}_{2} \mathrm{H}_{6}\right)^{e} \cdot P\left(\mathrm{O}_{2}\right)^{o} ;()$ : apparent activation energy $(\mathrm{kJ} / \mathrm{mol})$.

${ }^{a} \mathrm{CH}_{4} / \mathrm{O}_{2}>4$.

${ }^{b} \mathrm{CH}_{4} / \mathrm{O}_{2}<4$. 
Amorebieta and Colussi [174], for $\mathrm{PbO} / \mathrm{MgO}$ by Asami et al. [173], and for various catalysts by Sinev et al. [95, 175].

The reaction orders have also been determined by many investigators for the simple expression by power law, namely rate $=k\left(P_{\mathrm{A}}\right)^{\mathrm{a}}\left(P_{\mathrm{B}}\right)^{\mathrm{b}}$. The observed data are collected in Table 2 where the reaction orders for the formations of $\mathrm{C}_{2}$ and $\mathrm{CO}_{x}$ and also those for the dehydrogenation of ethane are listed. Included also in Table 2 are the apparent activation energies $(\mathrm{kJ} / \mathrm{mol})$ for the reactions, where available.

\section{Rate-Determining Step}

When Lunsford and his co-workers proposed the mechanism [reactions (3)-(24)], they assumed that the rate-determining step was the regeneration of the $\left[\mathrm{Li}^{+} \mathrm{O}^{-}\right]$centers [reactions (5)-(8)], which required high temperatures. Amorebieta and Colussi [174] claimed that $\mathrm{C}-\mathrm{H}$ bond breaking, namely the abstraction of the $\mathrm{H}$ atom, was the ratedetermining step on $\mathrm{Li} / \mathrm{MgO}$. The pressure they used, however, was extremely low (less than 0.1 torr) so that their conclusion may not be applied to other cases. From the observed isotope effect between $\mathrm{CH}_{4}$ and $\mathrm{CD}_{4}$ in methane coupling on $\mathrm{MgO}$ and $\mathrm{Li} / \mathrm{MgO}$ catalysts, Buevskaya et al. [176] and Cant et al. [177] also concluded that H-abstraction [reaction (4)] to be the rate-determining step. Reaction (5) will also exhibit an isotope effect, but the latter authors found no isotope effect by feeding $\mathrm{CH}_{4}+\mathrm{D}_{2} \mathrm{O}$. Otsuka et al. [164] also concluded from the observed kinetics that the abstraction of hydrogen atom was the slowest step on $\mathrm{Sm}_{2} \mathrm{O}_{3}$. When the methane coupling reaction was carried out with $\mathrm{N}_{2} \mathrm{O}$ on the same catalyst, the rate-determining step shifted to the decomposition of $\mathrm{N}_{2} \mathrm{O}$ [61].

In a study of the gas phase coupling reaction of methane, Lane and Wolf [178] found the apparent activation energy of methane conversion to be $228 \mathrm{~kJ} / \mathrm{mol}$ and pointed out that it was similar to the activation energies (234-240 kJ/mol) reported for the formation of methyl radicals in the gas phase from methane and molecular oxygen:

$$
\mathrm{CH}_{4}+\mathrm{O}_{2} \rightarrow \mathrm{CH}_{3}+\mathrm{HO}_{2}
$$

As they discussed, the value they observed was also close to the activation energy observed with various catalysts for methane conversion $[95,111]$ and for the $C_{2}$ formation $[16,29,173]$. If reaction (28) is the rate-determining step of the catalytic coupling reaction, however, the role of the surface $\mathrm{O}^{-}$species becomes uncertain. 
Mirodatos and Martin [169] observed in a transient experiment on $\mathrm{Li} / \mathrm{MgO}$ that the formation of $\mathrm{C}_{2}$ continued after the supply of oxygen was cut off whereas $\mathrm{C}_{2}$ formation stopped immediately after cutting the methane supply. From these observations, they concluded that the oxygen supply was not the rate-determining step. Lin et al. [124], however, concluded that it depends on the pressure of oxygen, and that the rate-determining step could be the oxygen supply when the oxygen pressure was lower than 20 torr.

Since the oxidative coupling reaction involves many elementary reactions, both on the surface and in the gas phase, the rate-determining step may shift from one elementary reaction to another, depending on the reaction conditions. The reaction temperature and the partial pressures of the reactants are likely factors to affect the rate-determining step. A noticeable fact revealed in Table 1 is that most of the large space time yields have been obtained with very small $W / F$ and that this trend is observed over the entire range of $W / F$. The STY is also affected by the partial pressures of the reactants. In order to minimize these effects the $S T Y$ entries in Table 1 were divided by the partial pressure of methane and plotted against $W / F$ with open symbols in Fig. 5, because $C_{2}$ formation is close to the first order for the methane pressure as shown in Table 2. The effect of oxygen pressure was not corrected since the reaction order for oxygen is usually small (Table 2). The $S T Y / P\left(\mathrm{CH}_{4}\right)$ thus derived may be regarded as the rate constant for the catalyst if the overall reaction is treated as a first-order catalytic reaction. Figure 5 shows that $S T Y / P\left(\mathrm{CH}_{4}\right)$ varies over four orders of magnitude with $W / F$. The figure also shows a good linear relationship over a wide range of $W / F$, independent of the catalyst used. Some differences in the temperatures ernployed for the reaction seem to have little effect. If the reaction is controlled by a catalytic process, the value of $S T Y / P\left(\mathrm{CH}_{4}\right)$ should be constant independent of $W / F$, but should depend on the catalyst. The results of Fig. 5, therefore, suggest that $\mathrm{C}_{2}$ formation is not controlled by a catalytic reaction.

If, on the other hand, the $\mathrm{C}_{2}$ formation reaction is controlled by a homogeneous process, the amount of $\mathrm{C}_{2}$ formed in a unit volume per unit time should be constant and independent of the catalyst. This amount may be calculated as $S T Y \cdot w / P\left(\mathrm{CH}_{4}\right) \cdot V_{\mathrm{r}}$ where $w$ is the weight of catalyst and $V_{\mathrm{r}}$ is the volume of the zone at the reaction temperature. Neglecting $V_{\mathrm{r}}$, since the information on $V_{\mathrm{r}}$ was scarce, the quantity $S T Y \cdot w / P\left(\mathrm{CH}_{4}\right)$ was calculated from Table 1 and plotted against $W / F$ (Fig. 5: filled symbols). As shown in the figure, the values of $S T Y \cdot w / P\left(\mathrm{CH}_{4}\right)$ do not change systematically with $W / F$ and most are in 


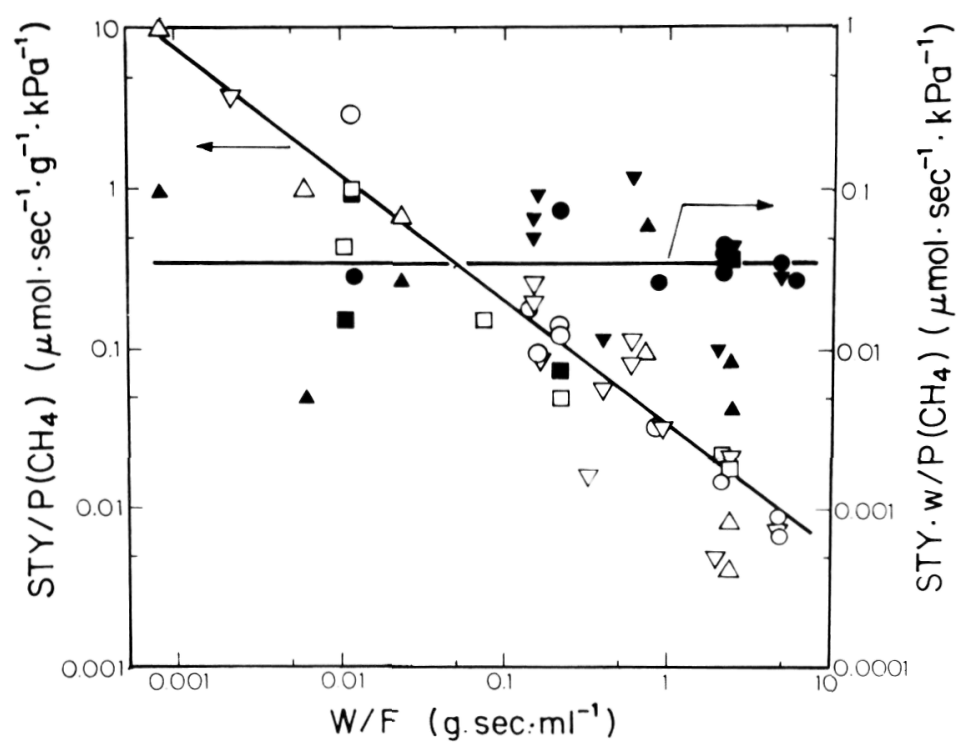

FIG. 5. Plot of rate of $\mathrm{C}_{2}$ formation versus $W / F$. Open symbols refer to $S T Y / P\left(\mathrm{CH}_{4}\right)$ and filled symbols to $S T Y / \cdot w / P\left(\mathrm{CH}_{4}\right)$. $\bigcirc$, : alkali (earth) metal/alkali earth metal oxide; $\triangle, \boldsymbol{\Delta}$ : lanthanide oxide; $\nabla, \boldsymbol{\nabla}$ : alkali (earth) metal/lanthanide oxide; $\square$, $\mathbf{\square}$ : other oxide catalysts.

the same order of magnitude, independent of the type of catalysts used and of the magnitude of $W / F$. Considering that the effect of $V_{\mathrm{r}}$ was ignored and that the temperature was not necessarily the same, $S T Y \cdot w / P\left(\mathrm{CH}_{4}\right)$ is fairly constant over a wide range of $W / F$, indicating that the coupling reactions listed in Table 1 are controlled by a homogeneous process instead of a catalytic one. The data collected in Table 1 have been selected from the highest yield reported in each paper. Naturally, most of them were obtained at high temperatures and with efficient catalysts. Under these conditions, the catalytic formation of methyl radicals will be fast and equilibrated so that the subsequent homogeneous reaction will become the rate-determining step for the formation of $\mathrm{C}_{2}$.

\section{OPTIMIZATION OF $\mathrm{C}_{2}$ YIELD}

Higher $\mathrm{C}_{2}$ yields in oxidative coupling of methane are obtainable by increasing the methane conversion or the $\mathrm{C}_{2}$ selectivity or both. 
Unfortunately, higher selectivity is usually observed at lower conversion for this process. Probably, the selectivity is the most important factor in the practical application of the coupling reaction. If the selectivity is high a high $C_{2}$ yield may be achieved by recycling the reactants. Many authors have discussed the selectivity in terms of the properties of the catalyst, the reaction conditions, and of the mechanism. High yield or selectivity may be achieved by improving the catalysts and by optimizing the reaction conditions. Various factors which affect the $\mathrm{C}_{2}$ yield in these two areas are discussed below.

\section{A. Catalysts}

The characterization of catalysts leading to the identification of active sites is essential to prepare efficient catalysts for methane coupling. As described in the previous section, Lunsford and his co-workers used EPR spectroscopy extensively to detect and identify the $\mathrm{Li}^{+} \mathrm{O}^{-}$centers as the active sites of Li-doped $\mathrm{MgO}$ catalysts. While they observed a good parallelism between the amount of $\mathrm{CH}_{3} \cdot$ radicals produced and that of the $\mathrm{Li}^{+} \mathrm{O}^{-}$centers [17], Wang and Lunsford also found from the dipolar broadening of EPR signals due to the adsorption of oxygen [32] that most of these centers were in the bulk of the catalyst. The relation between the surface concentration of these centers and the activity of the catalyst remains to be clarified.

Although the $\mathrm{Li}^{+} \mathrm{O}^{-}$center has been assumed by many authors on similar catalysts, an alternative nature of the active sites for $\mathrm{Li} / \mathrm{MgO}$ catalysts was proposed to be surface sites of lower coordination by Anpo et al. [179]. Photoluminescence of pure $\mathrm{MgO}$ shows only the emissions due to four-coordinate sites. With Li doping a second band was also observed, due to a lower coordination site, and the variation in intensity of this band with Li doping paralleled the oxidative coupling activity of the system. Although the relationship between the $\mathrm{Li}^{+} \mathrm{O}^{-}$ center and the low coordination site is not clear, the authors suggested that the latter shows a better correlation with the activity of $\mathrm{Li} / \mathrm{MgO}$ catalysts including undoped $\mathrm{MgO}$, which also shows some activity. By using TPD and EPR spectroscopy Ito et al. [27] reported that $\mathrm{MgO}$ could activate methane even below room temperature by dissociatively adsorbing methane heterolytically on the sites of $\mathrm{O}_{3 \mathrm{C}}^{2-}-\mathrm{Mg}_{3 \mathrm{C}}^{2+}$ and $\mathrm{O}_{3 \mathrm{C}^{-}}^{2-}$ $\mathrm{Mg}_{4 \mathrm{C}}^{2+}$. These ion pairs are in low coordination states on $\mathrm{MgO}$, but their participation in the methane coupling reaction at high temperatures remains to be proved. Iwamatsu et al. [34] found that the lattice distortion, as measured by the line broadening of XRD, and the surface area 
were related to the activity of alkali-doped $\mathrm{MgO}$ catalysts. Also with XRD Matsuura et al. [112] identified $\mathrm{Li}_{2} \mathrm{Be}_{2} \mathrm{O}_{3}$ as the active species on $\mathrm{Li} / \mathrm{BeO}$ catalyst.

An alternative approach to the active sites of $\mathrm{Li} / \mathrm{MgO}$ catalysts was suggested by Mirodatos et al. [49] from a study of catalyst deactivation. Under the reaction conditions employed for oxidative coupling, Li will exist during the reaction as molten $\mathrm{Li}_{2} \mathrm{CO}_{3}$ in equilibrium with $\mathrm{Li}_{2} \mathrm{O}$ and $\mathrm{CO}_{2}[21]$. The catalyst deactivates due to both magnesia sintering and loss of alkali. It was proposed [49] that $\mathrm{MgO}$, formed from the dehydration of $\mathrm{Mg}(\mathrm{OH})_{2}$, reversibly dissolved in the liquid $\mathrm{Li}_{2} \mathrm{CO}_{3}$, leading to the growth of larger crystals. The liquid $\mathrm{Li}_{2} \mathrm{CO}_{3}$ would also, of course, block smaller pores on the surface. For a catalyst in such a state of flux the concept of isolated, rigid $\mathrm{Li}^{+} \mathrm{O}^{-}$centers is difficult to reconcile. The precise role of each component and interaction in such catalysts promises to be a subject of much interest for some time.

The nature of deposited $\mathrm{LiCl}$, which promotes the activity of so many otherwise ineffective or nonselective oxidation catalysts, is not well characterized for most such systems. The melting point of $\mathrm{LiCl}$ is $878 \mathrm{~K}$, well below the operating temperatures of the promoted catalysts in question. It can therefore be expected that crystallites of $\mathrm{LiCl}$ will melt on the surface of metal oxides. Further, it can be expected that for many, if not all, complex salts will be formed which will also be molten. Thus the $\mathrm{LiCl}$ will not only modify the surface but will form new species and will even avail a homogeneous solution or liquid catalyst system.

The role of $\mathrm{NaCl}$ in modifying other systems may similarly involve surface liquid phases. The melting point of pure $\mathrm{NaCl}$ is $1074 \mathrm{~K}$, slightly higher than the operating temperature for many of the systems promoted with $\mathrm{NaCl}$. However, for impure $\mathrm{NaCl}$, or a mixed system, which would be expected to result from the method of deposition, the melting point will be depressed. Again, solutions in molten $\mathrm{NaCl}$ or complex salts would be expected to form on the surface of the catalyst.

The doping of catalysts with alkali metal ions induces a considerable increase in the catalytic activity and selectivity $[7,14,18,23,24,28$, $29,33,35,37,39,49,53,73,91,109,111,112,113,116,117,120$, $122,153,160,165,168,169,171,174,180-185]$. With an increasing amount of alkali metal content, the selectivity of the catalyst to hydrocarbon production increases and then usually attains a constant value. According to the results of Ito et al. [111], for example, the selectivity of $\mathrm{Li} / \mathrm{MgO}$ catalysts increased with an increasing amount of $\mathrm{Li}$ up to $7 \%$ and remained almost unchanged beyond this concentration, while 
the conversion of methane showed a maximum between $1 \%$ and $3 \%$ of $\mathrm{Li}$. The addition of $4 \mathrm{wt} \% \mathrm{Na}^{+}$(as $\mathrm{Na}_{2} \mathrm{O}$ ) to a $\mathrm{PbO} / \mathrm{Al}_{2} \mathrm{O}_{3}$ catalyst increased the selectivity by about $10 \%$ and the conversion of methane showed a maximum at about $2 \mathrm{wt} \% \mathrm{Na}^{+}$in a study by Hinsen et al. [14]. The effectiveness (selectivity to $C_{2}$ hydrocarbons and conversion) of alkali metal cation promotion decreases with increasing atomic weight of the metal $[113,116,117]$. For example, Otsuka et al. [116] obtained the best promoting effect of alkali cations on a $\mathrm{Sm}_{2} \mathrm{O}_{3}$ catalyst by the addition of $\mathrm{Li}$, increasing the selectivity from $40 \%$ for undoped $\mathrm{Sm}_{2} \mathrm{O}_{3}$ to $57 \%$ for 5 to $10 \mathrm{~mol} \% \mathrm{Li} / \mathrm{Sm}_{2} \mathrm{O}_{3}$.

Identification of active sites and of physical properties related to the activity has been reported for various catalysts. Imai et al. [54] found with $\mathrm{LaAlO}_{3}$ catalysts that the amorphous phase of the oxide was active, and that the $\mathrm{C}_{2}$ yield dropped as the extent of crystallization to perovskite increased. For $\mathrm{Ce}_{2} \mathrm{O}-\mathrm{Yb}_{2} \mathrm{O}_{3}$ (fluorite) and $\mathrm{SrO}-\mathrm{CeO}_{2}$ (perovskite) catalysts, Machida and Enyo [43] observed that the ionic conductivity, either by $\mathrm{O}^{2-}$ or by $\mathrm{H}^{+}$, showed a maximum or minimum. respectively, in the selectivity versus composition curves. Otsuka et al. [120] suggested that $\mathrm{BaCeO}$ found in a $\mathrm{Ba} / \mathrm{CeO}_{2}$ catalyst retards the formation of $\mathrm{CO}_{x}$ while $\mathrm{Ce}^{++}$is responsible for methane activation. For other oxides, Labinger et al. [12] found $\mathrm{Mg}_{6} \mathrm{MnO}_{8}$ species active for methane coupling in $\mathrm{Mn} / \mathrm{Mg}$ mixed oxides whereas Lo et al. [16] identified $\alpha-\mathrm{Sb}_{2} \mathrm{O}_{4}$ as the only antimony phase in $\mathrm{K}$-doped antimony catalysts which gave a high selectivity under the reaction conditions.

The acidity and basicity of the catalysts and the supports are important factors for the selectivity of the coupling reaction $[7,14,23,30$, 37, 66, 67, 70]. It was observed by Aika et al. [24] that the activity and selectivity of $\mathrm{Mg}, \mathrm{Ca}, \mathrm{Sr}$, and $\mathrm{Ba}$ oxide catalysts increased with increasing atomic weight of the element as a result of the increasing basicity of the catalyst. For example, the selectivity to $\mathrm{C}_{2}$ hydrocarbons increases from $11.7 \%$ over $\mathrm{MgO}$ to $45.4 \%$ over $\mathrm{BaO}$ [24]. Similarly, for a series of lanthanide oxides for methane coupling, Campbell et al. [48] found that the activity increased with increasing basicity of the oxides except for those metals with multiple stable oxidation states. In a study of a series of perovskite $\left(\mathrm{ABO}_{3}\right)$ catalysts, Nagamoto et al. [118] concluded that the basicity of the $\mathrm{A}$ ion in the oxide is closely related to the catalyst activity per unit surface area.

Typically, oxidative coupling catalysts operate at temperatures close to $1000 \mathrm{~K}$. At such temperatures, acidic catalysts are effective for catalyzing nonselective oxidation, and for cracking of higher hydrocarbons. Thus acidic catalysts can reduce the selectivity of coupling by car- 
bon-carbon bond breaking and by promoting the production of $\mathrm{CO}_{x}$. For this reason, higher selectivities are generally obtained with basic or less acidic supports such as alkaline earth metal oxides and silica than with those of stronger acidity such as alumina [7, 14, 37, 103]. Baerns and his co-workers $[14,37]$ demonstrated that the selectivity of $\mathrm{Pb} / \mathrm{Al}_{2} \mathrm{O}_{3}$ catalysts increased by adding $\mathrm{Na}_{2} \mathrm{O}$ or by increasing $\mathrm{Pb}$. For example, an increase in the $\mathrm{PbO}$ content from 6.5 to $36 \mathrm{wt} \%$ caused an increase in the $\mathrm{C}_{2}$ selectivity from $12.9 \%$ to $57.7 \%$ due to increasing coverage of acid sites by $\mathrm{Pb}$ [37]. Also for alkali-promoted lanthanide oxides, one of the functions of the alkali promoter is considered to be the poisoning of the sites for the nonselective oxidation, thus improving the selectivity $[30,120]$. Zhang et al. [96] observed with $\mathrm{Li} / \mathrm{ZnO}$ that the $\mathrm{ZnO}$ support acts as a sink for methyl radicals, and that $\mathrm{Li}$ poisons that function.

Although Baerns et al. [14, 37] explained the change in the selectivity of $\mathrm{Pb} / \mathrm{Al}_{2} \mathrm{O}_{3}$ in terms of acidity, as mentioned above, Sinev et al. [104] suggested that the function of $\mathrm{PbO}$ on $\mathrm{Pb} / \mathrm{Al}_{2} \mathrm{O}_{3}$ catalysts was to destroy methyl peroxide radicals $\left(\mathrm{CH}_{3} \mathrm{O}_{2} \cdot\right)$ which lead to the formation of $\mathrm{CO}_{x}$. Also some investigators found that the reduction of acidity does not reduce the $\mathrm{CO}_{x}$ production or improve the selectivity $[16,38,96]$.

The surface area of the catalyst is another factor correlated with the $\mathrm{C}_{2}$ yield of the coupling reaction. A larger surface area may appear to give higher yields of $\mathrm{C}_{2}$, since ethane is formed from methyl radicals which in turn are formed on the surface through reactions (4) and (10). However, undesirable side reactions and the total oxidation of methane and higher hydrocarbons also involve the surface of catalyst. Therefore, there will be an optimum specific surface area which is usually found to be very small for most catalysts. Iwamatsu et al. [33, 34] found with $\mathrm{Na} / \mathrm{MgO}$ catalysts that the catalysts with smaller specific surface areas generally gave higher yields of $\mathrm{C}_{2}$. Lin et al. [124] observed on $\mathrm{Na} / \mathrm{CaO}$ catalysts that the addition of $\mathrm{Na}$ reduced the surface area of the catalysts, thereby minimizing the nonselective oxidation and increasing the selectivity. The reduction of the surface area by adding an appropriate amount of sodium to $\mathrm{Mn} / \mathrm{SiO}_{2}$ catalysts was one of the major factors for increasing the yield of $\mathrm{C}_{2}$ as observed by Jones et al. [7]. When the highest selectivity of $\mathrm{Pb} / \mathrm{Al}_{2} \mathrm{O}_{3}$ catalysts was observed by Hinsen et al. [14] by increasing the $\mathrm{Pb}$ loading from $6.5 \%$ to $36 \%$ as described above, the specific surface area of the catalysts was reduced from 87 to $15 \mathrm{~m}^{2} / \mathrm{g}$.

Catalytic properties of oxides depend on the nature of the anion of the promoting salt. The most pronounced effect on activity and selectivity is observed in the case of halide addition $[28,70,71,79,122,182$, 
183]. The promoting effect of halides decreases in the order $\mathrm{Cl}>\mathrm{Br}>\mathrm{F}$ $[28,79,122,182]$. The highest promoting effect is seen by the chlorides of $\mathrm{Li}$ and $\mathrm{Na}$, although the nature of the support appears to play an important role as well. Ethylene is, of course, a more valuable product than ethane, and it is interesting to note that the high ratio of $\mathrm{C}_{2} \mathrm{H}_{4} / \mathrm{C}_{2} \mathrm{H}_{6}$ is obtained in the presence of halides, chloride in particular $[22,28,70,71,79,182]$. The mechanism of the promoting effect of halides has not been clear yet, but the promotion is probably partially due to the inhibition of nonselective oxidation processes. It was shown by Liu et al. [186] that $\mathrm{Pt}$ and $\mathrm{Pd}$, which catalyze the complete oxidation of $\mathrm{CH}_{4}$, were deactivated in the presence of $\mathrm{Cl}$ and $\mathrm{Br}$ derivatives. Shigapov et al. [187] also suggested for $\mathrm{CaCl}_{2} / \mathrm{CaO}$ catalyst that chlorine generated by the catalyst surface participated in the formation of $C_{2}$ in the gas phase. A patent [188] claimed that high yields of $\mathrm{C}_{3}$ and $\mathrm{C}_{4}$ hydrocarbons were obtained over catalysts containing divalent metals and a halogen. For example, the concentration of $\mathrm{C}_{4}$ hydrocarbons in the product mixture of methane oxidation over $\mathrm{CaBr}_{2} /$ pumice and $\mathrm{CaBr}_{2} / \mathrm{MgO}$ were $46.8 \%$ and $24.1 \%$, respectively [188].

At the high temperatures employed for the methane coupling reaction, the stability of the catalyst is an important factor for practical catalysts. Lithium is a widely used promoter, but it is lost at high temperatures because of its volatility [73, 109, 110]. Korf et al. [189] observed that the yield of $\mathrm{C}_{2}$ on $\mathrm{Li} / \mathrm{MgO}$ at $1073 \mathrm{~K}$ increased a little for the first $2 \mathrm{~h}$ and then dropped continuously, finally leveling off after $40 \mathrm{~h}$. In a test of the life of $\mathrm{Na} / \mathrm{Pr}_{6} \mathrm{O}_{11}$, Gaffney et al. [8] found that the methane conversion remained almost constant over a period of $3200 \mathrm{~h}$ whereas the $\mathrm{C}_{2}$ selectivity dropped from $63 \%$ to $54 \%$ between 50 and $100 \mathrm{~h}$. On the other hand, Lin et al. [124] observed a decrease in the formation of $\mathrm{CO}_{2}$ on $\mathrm{Na} / \mathrm{CaO}$ catalyst for the first $10 \mathrm{~h}$ whereas $\mathrm{C}_{2}$ formation remained unchanged up to $40 \mathrm{~h}$. As a result, the $\mathrm{C}_{2}$ selectivity increased initially. No significant loss of $\mathrm{Na}$ was observed.

\section{B. Reaction Conditions}

The effect of temperature on the oxidative coupling of methane has been investigated by many authors $[3,18,23,28,29,24,38,39,49$, $52,54,61,73,79,89,95,99,103,104,111,112,117,124,164,174$, $175,181,190-194]$. As one of the features of the methane coupling, it is often observed that the selectivity increases with increasing temperature $[18,28,38,59,79,99,103,104,111,124,164,181,192,193]$. This is expected because the activation energy of $C_{2}$ formation is usually 
much higher than that of $\mathrm{CO}_{x}$ formation as shown in Table 2. Therefore, more $\mathrm{C}_{2}$ is produced at high temperature than $\mathrm{CO}_{x}$. Lin et al. [124] also pointed out that the formation of $\mathrm{C}_{2}$ is of second order for $\mathrm{CH}_{3}$. radicals [reaction (10)] whereas that of $\mathrm{CO}_{x}$ is of first order [reactions (11) and (17)]. When more $\mathrm{CH}_{3}$. radicals are produced at higher temperatures, therefore, the increase in $\mathrm{C}_{2}$ becomes more than that in $\mathrm{CO}_{x}$.

The effect of the partial pressure of reactants $\left(\mathrm{CH}_{4}\right.$ and $\left.\mathrm{O}_{2}\right)$ on the oxidative coupling of methane has also been widely investigated [11, $12,29,52,59,61,103,111,112,164,169,174,181,191,193]$. The rate of formation and the $\mathrm{C}_{2}$ selectivity increase with increasing ratio of $P_{\mathrm{CH}_{4}} / P_{\mathrm{O} 2}$. Higher selectivities were also observed at lower partial pressures of oxygen by Lin et al. [52] and by Otsuka et al. [164] on lanthanide oxide catalysts. As shown in Table 2, the reaction order of oxygen for $\mathrm{C}_{2}$ formation is generally lower than that for $\mathrm{CO}_{x}$ formation so that $\mathrm{CO}_{x}$ becomes predominant at higher oxygen pressures. Sinev et al. [95, 178] derived the limiting selectivity as a function of oxygen pressure which also indicated a decrease in selectivity with higher pressures of oxygen. Since the secondary oxidation of $\mathrm{C}_{2}$ products to $\mathrm{CO}_{x}$ is fast, higher selectivities are expected at lower conversions with lower pressures of oxygen $[52,164]$. In the coupling reaction with a mixture of $\mathrm{CH}_{4}+\mathrm{O}_{2}$, the gaseous oxygen is responsible not only for the regeneration of the active oxygen species on the surface but also for the formation of $\mathrm{CO}_{x}$. Aika and Nishiyama $[35,195]$ discussed the use of $\mathrm{CO}_{2}$ as a possible oxidant which could oxidize only the surface sites (vide infra).

The type of oxidizing agent is also a relevant factor. Several attempts have been made to use oxidizing agents other than molecular oxygen in the oxidative coupling of methane, for example, nitrous oxide [61, 91, 94, 111, 119, 171, 180, 186, 191, 193, 196-199]; carbon dioxide [35, 195]; ozone [171]; and $\mathrm{NO}, \mathrm{NO}_{2}$, and $\mathrm{H}_{2} \mathrm{O}_{2}$ [191]. It was shown by Hutchings et al. [171] that $\mathrm{O}_{3}$ was a better oxidizing agent than $\mathrm{O}_{2}$ at low temperatures $(<670 \mathrm{~K})$ because of its ability to form atomic oxygen. However, the $\mathrm{C}-\mathrm{C}$ bond formation occurred at much higher temperatures $(\sim 870 \mathrm{~K})$ and only $\mathrm{CO}$ and $\mathrm{CO}_{2}$ were observed as oxidation products. Aika and Nishiyama $[35,195]$ claimed that the presence of $\mathrm{CO}_{2}$ and $\mathrm{O}_{2}$ in the mixture increased the yield of $\mathrm{C}_{2}$ hydrocarbons over mixed $\mathrm{PbO} / \mathrm{MgO}, \mathrm{PbO} / \mathrm{Na}_{2} \mathrm{O} / \mathrm{MgO}$, and $\mathrm{Pb} / \mathrm{CaO}$ catalysts. This was explained in terms of the transfer of one oxygen atom from $\mathrm{CO}_{2}$ to the lattice or surface to be used for hydrogen abstraction from $\mathrm{CH}_{4}$ to give $\mathrm{C}_{2}$ hydrocarbons. Oxidizing agents such as $\mathrm{NO}, \mathrm{NO}_{2}$, and $\mathrm{H}_{2} \mathrm{O}_{2}$, be- 
cause of their facility to donate oxygen, yielded essentially only nonselective products such as $\mathrm{CO}$ and $\mathrm{CO}_{2}$ as reported by Shepelev and Ione [191]. $\mathrm{N}_{2} \mathrm{O}$ used as an oxidizing agent showed the lowest activity and percentage of methane conversion for most of the oxide catalysts tested. However, Otsuka et al. [61, 119] showed that the selectivity to the coupling products was higher when $\mathrm{N}_{2} \mathrm{O}$ was used for all the rare earth metal oxides tested. The coupling reaction proceeds at temperatures lower than $870 \mathrm{~K}$ in the presence of $\mathrm{N}_{2} \mathrm{O}$, whereas temperatures higher than $870 \mathrm{~K}$ are required when $\mathrm{O}_{2}$ is used as oxidant. When $\mathrm{N}_{2} \mathrm{O}$ was used as oxidant, Hutchings et al. [94] reported that $\mathrm{C}_{2}$ hydrocarbon production proceeded with great selectivity $(72.8 \%)$ over $\mathrm{Li} / \mathrm{MgO}$ catalysts at temperatures as low as $826 \mathrm{~K}$. Thus, $\mathrm{N}_{2} \mathrm{O}$ is a peculiar oxidant, causing a selective coupling of methane at temperatures lower than $870 \mathrm{~K}$.

The role of the walls of the reaction vessel can be significant. In their pioneering work, Keller and Bhasin [3] showed that in a stainless steel cyclic system, significant amounts of methane were converted, only to $\mathrm{CO}_{2}$, at temperatures over $1073 \mathrm{~K}$, but that very low conversion to $\mathrm{CO}_{2}$ occurred over quartz at $873-1273 \mathrm{~K}$. In contrast, over Vycor glass, quartz glass, and various silicas, $\mathrm{C}_{2}, \mathrm{CH}_{2} \mathrm{O}, \mathrm{CO}$, and $\mathrm{CO}_{2}$ were produced, the relative amounts and overall conversion varying with the glass and reaction temperature according to Kastanas et al. [200]. The results of Lane and Wolf [178] also showed that type 304 stainless steel was active for $\mathrm{CO}_{x}$ formation at $1073 \mathrm{~K}$ whereas quartz and alumina were relatively inert. At elevated pressures, the wall effect becomes serious even at low temperatures. For example, Gesser et al. [201] reported that the "noncatalytic" conversion of methane with oxygen at $10-100 \mathrm{~atm}$ and $573-773 \mathrm{~K}$ varied from $0.7 \%$ to $13.4 \%$ when the surfaces of vessels were $\mathrm{Cu}, \mathrm{Ag}$, stainless steel, PTFE, or glass. The role of components assumed to be inert may instead be significant, for initiation by formation of methyl radicals, or for propagation or termination reactions giving either target products or oxides of carbon.

Since the oxidative coupling of methane involves both heterogeneous and homogeneous reactions, the reaction conditions affecting the homogeneous reactions are also important. The contributions of the gas phase reactions to the overall reaction become greater at high temperatures $[6$, $125,178]$. The temperature range in which the gas phase reactions become predominant seems to shift to lower temperatures at elevated pressures. In their investigation up to $585 \mathrm{kPa}$, Hutchings et al. [202] found that the gas phase reactions dominated even at $810 \mathrm{~K}$ when the pressure was $335 \mathrm{kPa}$ or higher. As a result, there were only minor 
differences between the presence and the absence of a $\mathrm{Li} / \mathrm{MgO}$ catalyst. Asami et al. [203] studied the homogeneous coupling reaction under still higher pressures and observed that the ethylene/ethane ratio increased with the pressure but that the $\mathrm{C}_{2}$ selectivity decreased from $60 \%$ at $0.35 \mathrm{MPa}$ to $45 \%$ at $1.6 \mathrm{MPa}$ with a marked increase in the formation of $\mathrm{CO}$.

The effect of reaction conditions on the homogeneous coupling reaction was studied in detail by Lane and Wolf [178] and Yates and Zlotin [125]. Because of the presence of the gas phase reactions, the empty space in the reactor affects the reaction. Van Kasteren et al. [185] investigated the effect of the space behind the catalyst bed and recognized that the homogeneous dehydrogenation of ethane took place in this space when no oxygen remained. In the presence of oxygen, however, they found that the empty space behind the catalyst acted as an afterburner of hydrocarbons.

\section{METHANE CONVERSION IN RELATED PROCESSES}

\section{A. Conversion by Superacid}

A very interesting route for the production of higher hydrocarbons is the methane-alkene coupling reaction using superacids as demonstrated by Olah [204] with $\mathrm{SbF}_{5}-\mathrm{HF}$ and $\mathrm{SbF}_{5}-\mathrm{FSO}_{3} \mathrm{H}$, and by Scurrell [205] with sulfate-treated zirconia catalysts. The high electrophilicity of such reagents can effect activation of hydrocarbons, including methane [206]. The thermodynamic diagrams show [207] that the extent of conversion in methane alkene coupling is increased by a decrease in temperature and an increase in pressure. Siskin and Mayer [208] have shown that the $\mathrm{CH}_{4}-\mathrm{C}_{2} \mathrm{H}_{4}$ mixture can be converted to propane with $40-60 \%$ selectivity and the $\mathrm{C}_{2} \mathrm{H}_{6}-\mathrm{C}_{2} \mathrm{H}_{4}$ mixture to $n$-butane using $\mathrm{TaF}_{5}-\mathrm{HF}$ as the catalyst. Reactions were typically carried out at a temperature of ca. $40^{\circ} \mathrm{C}$ and at a pressure of about $1 \mathrm{MPa}$. As has been shown by Scurrell [205], the sulfate-treated zirconia interacts strongly with methane, possibly activating this reactant to react with ethylene as well as enabling ethylene to oligomerize at a high rate. The $\mathrm{C}_{6}$ and $\mathrm{C}_{7}$ hydrocarbons dominate initially, but the lighter products are formed at longer times on stream as a result of a decrease in the catalytic activity.

For $\mathrm{SbF}_{5}$ or $\mathrm{FSO}_{3} \mathrm{H}$ the acid also acts as the oxidant, thereby overcoming the thermodynamic constraint of hydrogen generation. The mechanism differs significantly from that of metal-based catalyst sys- 
tems, being cationic [reaction (29)]. Carbocations generated by superacids also react with unsaturates to form even higher hydrocarbons [reaction (30)] [209].

$$
\begin{aligned}
& \mathrm{CH}_{4}+\mathrm{HA} \rightarrow \mathrm{CH}_{5}^{+}+\mathrm{A}^{-} \rightarrow \mathrm{CH}_{3}^{+}+\mathrm{H}_{2}+\mathrm{A}^{-} \\
& \mathrm{CH}_{4}+\mathrm{RCH}: \mathrm{CH}_{2} \stackrel{[\mathrm{HA}]}{\longrightarrow}\left(\mathrm{CH}_{3}\right)_{2} \mathrm{CHR}
\end{aligned}
$$

Thus, superacids which can also behave as oxidants can convert $\mathrm{CH}_{4}$ to $\mathrm{C}_{2}$ and promote $\mathrm{C}_{2}$ to $\mathrm{C}_{3+}$, to give a range of hydrocarbons.

Until now, very few studies have been conducted in continuous-flow reactors employing superacids [205, 210-212]. Of these, the work of Olah et al. [212] on the ethylation of methane with ethylene in a pressurized fixed-bed reactor system seems to be of importance. In a recent review of superacid chemistry and superacid-catalyzed reactions, Olah et al. [213] emphasized the need for the development of new solid superacid catalysts with a long process life and improved regenerability.

\section{B. Conversion Via Oxychlorination}

As described in the introduction, the coupling of methane becomes thermodynamically feasible by introducing $\mathrm{O}_{2}$ as the oxidant as shown by reaction (2). However, the oxidant is not limited to oxygen. For example:

$$
2 \mathrm{CH}_{4}+\mathrm{Cl}_{2} \rightleftarrows \mathrm{C}_{2} \mathrm{H}_{6}+2 \mathrm{HCl} \Delta \mathrm{G}^{\circ}=-130.6 \mathrm{~kJ} \mathrm{~mol}^{-} \text {at } 1000 \mathrm{~K}
$$

A patent claimed a noncatalytic process in which a mixture of natural gas and chlorine was reacted at high temperatures $(970-1980 \mathrm{~K})$ to produce higher hydrocarbons, mainly ethylene and hydrogen chloride [214]. Hydrogen chloride is oxidized back to chlorine (Deacon reaction) so that the overall reaction becomes identical to the coupling reaction with oxygen. Shigapov et al. [187] suggested for the oxidative coupling of methane carried out on a $\mathrm{CaCl}_{2} / \mathrm{CaO}$ catalyst that chlorine generated by the catalyst surface participated in the formation of $\mathrm{C}_{2}$ in the gas phase, as already mentioned.

Oxychlorination (oxyhydrochlorination) is an oxidative condensation of hydrocarbon with chlorine (hydrogen chloride) and oxygen. An example of the industrial applications of this process is the production of vinyl chloride monomer from ethylene, hydrogen chloride, and oxygen. 
When the olefin is replaced by methane, chloromethanes are formed under moderate conditions.

Catalysts, mainly $\mathrm{CuCl}_{2} / \mathrm{KCl} / \mathrm{SiO}_{2}$, have recently been developed for this process [215,216]. It is also known that methyl chloride is oligomerized by dehydrohalogeno-condensation to higher hydrocarbons over oxide catalysts such as silica-alumina [217]. The yield of higher hydrocarbons over silica-alumina, however, is not very high because of a high conversion to methane. Methyl chloride is a monofunctionalized methane so that its oligomerization can be carried out efficiently with the ZSM-5 catalyst system developed by Mobil Corp., similarly to the case of methanol [218]. A methane conversion process recently proposed by the Pittsburgh Energy Technology Center [194] combines these two processes, the oxychlorination with $\mathrm{CuCl}_{2} / \mathrm{KCl} / \mathrm{SiO}_{2}$ and the oligomerization with ZSM-5 in series. The temperature is modest $(600 \mathrm{~K})$ and the products are mainly aromatics. The methane conversion through oxychlorination is not a direct conversion at present. However, the overall reaction is an oxidative condensation of methane and it is attractive because the main product is the gasoline-range liquid instead of $\mathrm{C}_{2}$ and because the reaction temperature is much lower than that for the oxidative coupling reaction.

\section{Electrochemical Conversion}

The electrochemical conversion of methane to higher hydrocarbons is an interesting possible route for the utilization of natural gas. The application of an electrical potential to a catalyst surface could significantly reduce the reaction activation energy barrier, influence the nature of the charge-transfer reactions which occur at the catalyst surface, and stabilize the reaction intermediates on the catalyst surface which are responsible for methane coupling. It is possible that precise control of the electrode potential could direct the course of the reaction towards expected products.

The literature concerning electrochemical methane conversion is relatively extensive and concerns both electrochemical oxidation of methane (or higher hydrocarbons) at metallic anodes and the conversion of methane in hydrocarbon-based fuel cells. A comprehensive survey of the literature of this field up to the end of the 1960s is given in the review by Cairns [219].

Most investigators have used platinum or platinoid elements as the working electrode. The oxidation of methane (and other hydrocarbons) at electrodes is related to its dissociative adsorption on metallic and 
metal oxides surfaces, as mentioned earlier. Table 3 shows the scope of the available literature results concerning the adsorption and anodic oxidation of methane. This table contains the reaction conditions, electrochemical methods used, and the intermediates and/or products of methane oxidation. Table 4 contains the data concerning the oxidation of methane at porous fuel cells electrodes. The results given in both tables show that methane oxidation at noble metals in acidic aqueous solutions is complete $\left(\mathrm{CO}_{2}\right.$ formation). In alkaline solutions, methane is not adsorbed and oxidized [228, 233, 251] because an oxygen-containing chemisorbed hydroxy-layer is formed on the Pt electrodes [233]. In acidic solutions, methane is weakly and slowly adsorbed on platinum in comparison to higher hydrocarbons $[220,225,227,228,233,235$, 245]. This chemisorption is dissociative and accompanied by the formation of surface species which are tightly bound to the surface and not readily desorbed by cathodic hydrogenation.

A single oxidation current peak near $0.7 \mathrm{~V}$ is observed during potential sweep experiments $[132,142,143,234]$, which is a measure of the amount of methane adsorbed prior to its oxidation to $\mathrm{CO}_{2}$. The maximum amount of methane is adsorbed at $0.3 \mathrm{~V}$ versus SHE (corresponding charge density is $140 \mu \mathrm{C} / \mathrm{cm}^{2}$ [132], which is approximately one monolayer). The rate of methane adsorption increases with temperature $[132,220]$, which is consistent with a chemisorptive rate-determining step. Methane adsorption should also be dependent on the nature of the electrolyte anions because they compete with methane molecules for adsorption sites. In fact, according to expectations, the extent of $\mathrm{CH}_{4}$ adsorption is greatest in $\mathrm{HClO}_{4}$ solutions, followed by $\mathrm{H}_{3} \mathrm{PO}_{4}$ and $\mathrm{H}_{2} \mathrm{SO}_{4}$ [219].

The identity of the surface species resulting from methane adsorption is not certain, but calculations of the number of electrons per Pt site required for the oxidation of the adsorbate suggests that they may be $\equiv \mathrm{COH},-\mathrm{CHO}$, or some similar species $[220,227]$. These chemisorbed, partially oxidized species, which can be oxidized further near $0.7 \mathrm{~V}$ but are not cathodically desorbable, have been termed by some authors as "O-type" $[134,135,220,225,255]$ or "reduced $\mathrm{CO}_{2}$ " [132, 256-259]. It should be added that the oxidation of higher hydrocarbons leads to different chemisorbed species termed - $\mathrm{CH}$ (partially dehydrogenated alkyl radicals), which can be desorbed cathodically, and also nondesorbable $\beta-\mathrm{CH}$ species carbonaceous polymer) [225, 255]. $\alpha-\mathrm{CH}$ can be oxidized at potentials of ca. $1.2 \mathrm{~V}$, while $\beta-\mathrm{CH}$ is stable to still higher potentials (as high as $1.9 \mathrm{~V}$ ) [219]. Arvia et al. [142, 143] proposed $-\mathrm{COH}$ and $-\mathrm{CO}$ as the adsorbed species during the potentiody- 
TABLE 3

Adsorption and Anodic Oxidation of Methane

\begin{tabular}{|c|c|c|c|c|c|}
\hline Electrode & Electrolyte & $\mathrm{T}\left({ }^{\circ} \mathrm{C}\right)$ & Methods & Products & Ref. \\
\hline $\mathrm{Pt}, \mathrm{Pt} / \mathrm{Pt}$ & $80 \% \mathrm{H}_{3} \mathrm{PO}_{+}$ & 130 & MPG. AS & O-type. $\mathrm{CO}_{2}$ & {$[22()]$} \\
\hline Pt. Ir, Ru, Rh & $85 \% \mathrm{H}_{3} \mathrm{PO}_{4}$ & 140 & E. GC & $\mathrm{CO}_{2}$ & {$[221]$} \\
\hline $\mathrm{Pt}$ & $80 \% \mathrm{H}_{3} \mathrm{PO}_{4}$ & 130 & MPG, AS & O-type $(\equiv \mathrm{C}-\mathrm{OH}) \stackrel{\mathrm{V} \cdots}{\longrightarrow} \mathrm{CO}$ & {$[134]$} \\
\hline Pt microdisk & Solv. $\mathrm{CH}_{3} \mathrm{CN}$ & $?$ & LSV & $\mathrm{CH}_{3}+\mathrm{CH}_{3} \mathrm{CN} \rightleftarrows \mathrm{CH}_{3} \mathrm{~N}^{\prime} \mathrm{CCH}_{3}$ & [222] \\
\hline Pt-black & $2 M \mathrm{NaClO}_{4}$ in butyrolactone & 23 & $\mathrm{P}$ & $\begin{array}{l}\mathrm{E}<0.8 \mathrm{~V} . \mathrm{CO} \\
\mathrm{E}=0.8 \mathrm{~V} .\left(\mathrm{CH}_{3}\right)_{\mathrm{iad}} \rightarrow \text { interm. }\end{array}$ & {$[223]$} \\
\hline $\mathrm{Pt}$ & $0.6 \mathrm{M} \mathrm{KCl} . \mathrm{pH}=11$ & 25 & P. PH & $\mathrm{CH}_{3} \mathrm{Cl} . \mathrm{CH}_{3} \mathrm{OH} . \mathrm{CH}_{2} \mathrm{Cl}_{2}, \mathrm{CHCl}_{3}$ & {$[224]$} \\
\hline Pt & Solv. $\mathrm{CF}_{3} \mathrm{SO}_{3} \mathrm{H} \cdot \mathrm{H}_{2} \mathrm{O}$ & $95-130$ & $\mathrm{P}$ & $\mathrm{O}$-type $\rightarrow \mathrm{CO}_{2}$ & {$[225]$} \\
\hline $\mathrm{Pt} / \mathrm{Pt}$ & $0.5 \mathrm{M} \mathrm{H}_{2} \mathrm{SO}_{4}$ & 80 & $\mathrm{P}$ & $\left(\mathrm{CH}_{3}\right)_{\mathrm{in} 1} \stackrel{\mathrm{dw}}{\longrightarrow}$ interm. $\rightarrow \mathrm{CO}_{2}$ & [226] \\
\hline Pt-black & $4.3 \mathrm{M} \mathrm{HClO}_{4}$ & 65 & MPP & $\mathrm{O}$-type $\rightarrow \mathrm{CO}_{2}$ & [132] \\
\hline Pt-black & $75 \% \mathrm{H}_{3} \mathrm{PO}_{4}$ & $60-120$ & MPP. P & $\mathrm{O}-\mathrm{type} \rightarrow \mathrm{CO}_{2}$ & [227] \\
\hline Pt-black & $2.5 \mathrm{MH}_{2} \mathrm{SO}_{4}, 6 \mathrm{MKOH}, 3 M \mathrm{KHCO}_{3}$ & $25-65$ & G.V.VPC & $\mathrm{CO}_{2}$ & {$[228]$} \\
\hline $\mathrm{Pt} / \mathrm{Pt}$ & $22 M \mathrm{KF}$ & 80 & P. CV & $(\mathrm{HCO})_{i a l}$ & [139] \\
\hline $\mathrm{Pt}$ & $0.5-10 M \mathrm{FSO}_{3} \mathrm{H}$. Solv. $\mathrm{CF}_{3} \mathrm{COOH}$ & 25 & CV.E & $\left(\mathrm{CH}_{4} \cdots \cdot \mathrm{H}\right)^{+} \rightarrow$ product & [229] \\
\hline $\mathrm{Pt} / \mathrm{Pt}$ & $0.5 \mathrm{M} \mathrm{H}_{2} \mathrm{SO}_{+}$ & 26 & G & $(\mathrm{COH})_{: \mathrm{al}} \cdot(\mathrm{CO})_{\mathrm{inl}}$ ? & {$[232]$} \\
\hline Pt-Raney & $1.5 \mathrm{MH}_{2} \mathrm{SO}_{+} .6 .5 M \mathrm{KOH}$ & $40-100$ & G. P & $\left(\mathrm{CH}_{1}\right)_{\mathrm{a} 1 \mathrm{1}} \rightarrow \mathrm{CO}_{2}$ & {$[233]$} \\
\hline $\mathrm{Pt} / \mathrm{Cu}$ monolayer & $80 \% \mathrm{H}_{3} \mathrm{PO}_{+}$ & 130 & MPG, AS & O-type $(\equiv \mathrm{C}-\mathrm{OH}) \stackrel{-\mathrm{l}+\cdots}{\longrightarrow} \mathrm{CO}_{2}$ & [135] \\
\hline Pt-Raney/Au & $1.5 M \mathrm{H}_{2} \mathrm{SO}_{+} .8 .7 M \mathrm{H}_{3} \mathrm{PO}_{+}$ & $90-110$ & CV.P.G & $\mathrm{CO}_{2}$ & [234] \\
\hline $\mathrm{Pt}$ & $0.5 \mathrm{MH}_{2} \mathrm{SO}_{4}, 0.33 \mathrm{M} \mathrm{H}_{3} \mathrm{PO}_{4}$ & $80-90$ & P. C & $\left(\mathrm{CH}_{1}\right)_{\mathrm{ata}} \rightarrow \mathrm{CO}_{2}$ & {$[235]$} \\
\hline $\mathrm{Pt}, \mathrm{Pt} / \mathrm{Pt}$ & $80-95 \% \mathrm{H}_{3} \mathrm{PO}_{4}+(0.3 \div 16) \cdot 10^{3} M \mathrm{Ni}^{2-}$ & 130 & MPG & $\mathrm{CO}_{2} ?$ & {$[236]$} \\
\hline $\mathrm{Pt}$ & $80 \% \mathrm{H}_{3} \mathrm{PO}_{4}+\mathrm{Cu}^{2+}, \mathrm{Ni}^{2+}, \mathrm{Al}^{3+}, \mathrm{Na}^{1}$ & 130 & MPP & $\mathrm{CO}_{2}$ & {$[237]$} \\
\hline
\end{tabular}

Abbreviations. AS-anodic stripping, C-coulometry, CV-cyclic voltammetry, E-electrolysis, G-galvanostatic, LSV - linear sweep voltammetry, MPG - multipulse galvanostatic, MPP-multipulse potentiodynamic, P-potentiostatic, PH-photochemical, V-volumetric, VPC-vapor-phase chromatography. 
TABLE 4

Methane Oxidation on Fuel Cell Electrodes

\begin{tabular}{|c|c|c|c|c|c|}
\hline Electrocatalyst & Electrolyte & $\mathrm{T}\left({ }^{\circ} \mathrm{C}\right)$ & $\begin{array}{c}i /\left[\mathrm{mA} \mathrm{cm}^{2} \mathrm{at}\right. \\
E=0.5 V(\mathrm{SHE})]\end{array}$ & Products & Ref. \\
\hline Prorous $\mathrm{Ag}$ on $\mathrm{Li} / \mathrm{MgO}$ & $\mathrm{ZrO}_{2}\left(8 \% \quad \mathrm{Y}_{2} \mathrm{O}_{3}\right)$ & 700 & - & $\mathrm{CO}_{2}, \mathrm{CO}, \mathrm{C}_{2} \mathrm{H}_{4}, \mathrm{C}_{2} \mathrm{H}_{6}$ & {$[2.38]$} \\
\hline Pt-black & $85 \% \mathrm{H}_{3} \mathrm{PO}_{4}$ & 150 & 50 & $\mathrm{CO}_{2}+$ adsorbed residues & {$[239]$} \\
\hline $\mathrm{Pt}$ & $85 \% \mathrm{H}_{3} \mathrm{PO}_{4}$ & 150 & 40 & $\mathrm{CO}_{2}$ & [240] \\
\hline Porous Au. Pt & $\mathrm{ZrO}_{2}\left(\mathrm{Sc}_{2} \mathrm{O}_{3}\right)$ & $700-800$ & 100 & $\mathrm{CO}_{2}, \mathrm{HCOH}, \mathrm{CH}_{3} \mathrm{OH}$ & [241] \\
\hline $\mathrm{Pt} / \mathrm{Pt}$ & Solv. $\mathrm{CF}_{3} \mathrm{SO}_{3} \mathrm{H} \cdot \mathrm{H}_{2} \mathrm{O}$ & $80-100$ & 0.03 & $\mathrm{CO}_{2} ?$ & {$[242]$} \\
\hline $\mathrm{Pt}$ & Solv. $\mathrm{CF}_{3} \mathrm{SO}_{3} \mathrm{H} \cdot \mathrm{H}_{2} \mathrm{O}$ & $95-1.30$ & $1.7 \times 10^{-3}$ & O-type $\rightarrow \mathrm{CO}_{2}$ & {$[225]$} \\
\hline Pt-Raney & $1.5 \mathrm{M} \mathrm{H}_{2} \mathrm{SO}_{4}$ & 100 & 150 & $\mathrm{CO}_{2}$ & [243] \\
\hline Porous $\mathrm{Pt}$ & $\left(\mathrm{ZrO}_{2}\right)_{01 \leqslant 5}(\mathrm{CaO})_{0115}$ & 1016 & 70 & $\mathrm{CO}_{2} \cdot \mathrm{CO} \cdot \mathrm{H}_{2}$ & [244] \\
\hline Pt. Pd-black & Sulfonated phenol formaldehyde & $27-85$ & - & $\mathrm{CO}_{2}$ & {$[245]$} \\
\hline $\mathrm{Pt}$ & $\mathrm{HF}-\mathrm{CsF}-\mathrm{H}_{2} \mathrm{O}$ & $105-150$ & 55 & $\mathrm{CO}_{2}$ & {$[246]$} \\
\hline $\mathrm{Ag}$ & $\mathrm{ZrO}_{2}\left(8 \% \quad \mathrm{Y}_{2} \mathrm{O}_{3}\right)$ & 850 & - & $\mathrm{CO}_{2}, \mathrm{C}_{2} \mathrm{H}_{2}, \mathrm{C}_{2} \mathrm{H}_{6}$ & {$[247]$} \\
\hline $28 \mathrm{wt} \% \mathrm{Bi}_{2} \mathrm{O}_{3} / \mathrm{Ag}$ & $\mathrm{ZrO}_{2}\left(8 \% \quad \mathrm{Y}_{2} \mathrm{O}_{3}\right)$ & 850 & - & $\mathrm{CO}_{2} \cdot \mathrm{C}_{2} \mathrm{H}_{2} \cdot \mathrm{C}_{2} \mathrm{H}_{6}$ & {$[247]$} \\
\hline $\mathrm{Ag}$ & $\mathrm{ZrO}_{2}\left(8 \% \quad \mathrm{Y}_{2} \mathrm{O}_{3}\right)$ & 800 & - & $\mathrm{CO}_{2} \cdot \mathrm{C}_{2} \mathrm{H}_{4} \cdot \mathrm{C}_{2} \mathrm{H}_{t}$ & {$[47]$} \\
\hline $\mathrm{Bi}_{2} \mathrm{O}_{3} / \mathrm{Ag}$ & $\mathrm{ZrO}_{2}\left(8 \% \quad \mathrm{Y}_{2} \mathrm{O}_{3}\right)$ & 800 & - & $\mathrm{CO}_{2} \cdot \mathrm{C}_{2} \mathrm{H}_{4} \cdot \mathrm{C}_{2} \mathrm{H}_{6}$ & {$[47]$} \\
\hline $\mathrm{Ag}$ & $\mathrm{ZrO}_{2}\left(8 \% \quad \mathrm{Y}_{2} \mathrm{O}_{3}\right)$ & $450-600$ & - & $\mathrm{CO}_{2}$ & {$[248\}$} \\
\hline $\mathrm{Ag}$ & $\mathrm{ZrO}_{2}\left(8 \% \quad \mathrm{Y}_{2} \mathrm{O}_{3}\right)$ & $450-600$ & - & intermediate $\rightarrow \mathrm{CO}_{2}+\mathrm{H}_{2} \mathrm{O}$ & [249] \\
\hline $\mathrm{Pt} / \mathrm{Sm}_{2} \mathrm{O}_{3} / \mathrm{La}_{4, x y} \mathrm{Sr}_{4,10} \mathrm{MnO}_{3}$ & $\mathrm{ZrO}_{2}\left(8 \% \quad \mathrm{Y}_{2} \mathrm{O}_{3}\right)$ & 760 & - & $\mathrm{C}_{2} \mathrm{H}_{1}, \mathrm{C}_{2} \mathrm{H}_{4}, \mathrm{C}_{2} \mathrm{H}_{2}$ & {$[250]$} \\
\hline Pt-Raney/Au & $8.7 \mathrm{MH}_{3} \mathrm{PO}_{4}$ & 110 & 85 & $\mathrm{CO}_{2}$ & {$[234,251]$} \\
\hline Pt-Raney/Au & $1.5 \mathrm{M} \mathrm{H}_{2} \mathrm{SO}_{4}$ & 90 & 70 & $\mathrm{CO}_{2}$ & [2.34] \\
\hline Pt. Au & $\left(\mathrm{ZrO}_{2}\right)_{1, v_{2}}\left(\mathrm{Sc}_{2} \mathrm{O}_{3}\right)_{0,1 \mathrm{x}}$ & 700 & - & $\mathrm{CO}_{2} ?$ & [252] \\
\hline $\mathrm{Pt}$ & $85 \% \mathrm{H}_{3} \mathrm{PO}_{4}$ & 150 & 50 & $\mathrm{CO}_{2}$ & [253] \\
\hline Pt. Au & $\mathrm{ZrO}_{2}\left(8 \% \quad \mathrm{Sc}_{2} \mathrm{O}_{3}\right)$ & $700-850$ & - & $\mathrm{CO}_{2} ?$ & [254] \\
\hline $\mathrm{Pt}$ & $\begin{array}{l}80-95 \% \mathrm{H}_{3} \mathrm{PO}_{4} \\
+(0.3 \div 16) \cdot 10^{-3} \mathrm{M} \mathrm{Ni}^{2-}\end{array}$ & 130 & - & $\mathrm{CO}_{2} ?$ & {$[256]$} \\
\hline
\end{tabular}


namic oxidation of methane in $0.5 \mathrm{M} \mathrm{H}_{2} \mathrm{SO}_{4}$ solutions. The contribution of both species depends on the potential and time of adsorption. The - $\mathrm{CO}$ species can be transformed to $-\mathrm{COH}$ by electrochemical reduction in the potential range of hydrogen adsorption.

A survey of the literature shows that the electrochemical oxidation of methane in aqueous solutions at noble metal electrodes ultimately leads to complete oxidation to $\mathrm{CO}_{2}$. At low electrode potentials, it would be possible to generate partially oxidized, nondesorbable, but not useful, molecular residues. It is likely that these active and desorbable intermediates (radicals, ions) would react immediately with surrounding water molecules leading to the complete oxidation products $\left(\mathrm{CO}, \mathrm{CO}_{2}\right)$.

Several attempts have been made to anodically oxidize methane in nonaqueous solvents or molten salts electrolytes [222, 223, 225, 229$231,242,245]$. There is no evidence for the production of compounds other than $\mathrm{CO}_{2}$ and $\mathrm{H}_{2} \mathrm{O}$. Intermediates such as $\mathrm{CH}_{3}^{+}$were postulated in acetonitrile [222]; $\left(\mathrm{CH}_{3}\right)_{\text {ad }}$ in $\gamma$-butyrolactone [223]; $\mathrm{CF}_{3} \mathrm{SO}_{3} \mathrm{H}$ [230], $\left(\mathrm{CH}_{4} \cdots \cdot \mathrm{H}\right)^{+}$in trifluoroacetic acid [229]; and $\mathrm{C}_{2} \mathrm{H}_{6}, \mathrm{CH}_{3}^{+}, \mathrm{CH}_{3} \cdot$, and $\mathrm{CH}_{5}^{+}$in anhydrous $\mathrm{HF}-\mathrm{SbF}_{5}$ system [231]. These latter species are likely to deactivate by reaction with solvent or solvent impurities [222].

The only approach which has led to the electrochemical production of hydrocarbons from methane involved the use of high-temperature fuel cell systems with zirconia as a solid electrolyte (see Table 4). The hydrocarbon fuel cells based on platinum and aqueous electrolytes are a good electrical power source, but the oxidation of hydrocarbons is complete (to $\mathrm{CO}_{2}$ ) and no other useful chemical products are formed.

In a short review, Tannenberger [260] has described the advantages and problems of the high-temperature $\mathrm{ZrO}_{2}$-solid electrolyte fuel cells. The zirconia electrolyte stabilized by scandia or yttria is a good oxygen ion conductor. In these systems, the anode is exposed to a fuel and the cathode is exposed to oxygen or air. The oxygen is reduced at the cathode, and oxide ions migrate through the electrolyte via a vacancy mechanism. A stabilized $\mathrm{ZrO}_{2}$ surface contains a variety of catalytically active sites, such as oxygen vacancies and host cations $\left(\mathrm{Y}^{3+}, \mathrm{Sc}^{3+}\right.$, $\mathrm{Zr}^{4+}$ ). Nguyen, Liu, and Mason [241] obtained $\mathrm{HCOH}$ and $\mathrm{CO}$ as products of partial $\mathrm{CH}_{4}$ oxidation in the scandia-stabilized zirconia electrolyte, using porous $\mathrm{Au}$ and Pt anodes. Unfortunately, the selectivity and extent of conversion were not given.

Seimanides and Stoukides [238] observed $\mathrm{C}_{2} \mathrm{H}_{4}$ and $\mathrm{C}_{2} \mathrm{H}_{6}$ formation in yttria-stabilized zirconia fuel cells with a porous $\mathrm{Ag}$ catalyst as the anode. They used an "oxygen pumping" technique, which appears to significantly alter the electrode properties. Upon imposing an external 
voltage across the cell, oxygen was pumped electrochemically to or from the electrode catalyst. The rate of $\mathrm{CO}_{2}$ formation increased considerably when oxygen was pumped to the catalyst, whereas the rate of $\mathrm{C}_{2} \mathrm{H}_{4}$ formation decreased. Oxygen pumping does not influence the rate of $\mathrm{C}_{2} \mathrm{H}_{6}$ production; that is, the selectivity to $\mathrm{C}_{2}$ hydrocarbon formation decreases. This behavior is completely different from that of ethylene and propylene oxidation on $\mathrm{Ag}[261,262]$, where the enhancement of ethylene and propylene oxide production during oxygen pumping was two orders of magnitude higher than the rate of oxygen transport through the electrolyte. This phenomenon was explained by the formation of a catalytically active surface of silver oxide at the anode. Similar electrocatalytic effects were unfortunately not observed in the case of $\mathrm{CH}_{4}$ oxidation.

Otsuka et al. [47, 263] and Eng and Stoukides [247] observed $C_{2}$ hydrocarbon formation with great selectivity in a yttria-stabilized zirconia fuel cell system with porous $\mathrm{Ag}$ electrodes which were mixed [247] or coated [47, 263] with $\mathrm{Bi}_{2} \mathrm{O}_{3}$. Bismuth oxide addition to the $\mathrm{Ag}$ catalyst improves the $\mathrm{C}_{2}$ selectivity from ca. $35 \%$ to ca. $90 \%$ [247] and, in another study, from ca. $52 \%$ to ca. $67 \%$ [47]. However, the methane conversion was very low $(2-4 \%)$ [247]. In the case of pure Ag anodes, the selectivity to $\mathrm{C}_{2}$ hydrocarbons decreases sharply with increasing oxygen pressure (oxygen flux) over the cathode. This can be explained by the burning of the $\mathrm{C}_{2} \mathrm{H}_{6}$ and $\mathrm{C}_{2} \mathrm{H}_{4}$ produced [47]. Therefore, the reaction should be carried out with low oxygen pressure as far as the selectivity of $\mathrm{C}_{2}$ hydrocarbons is concerned. However, when oxygen is electrochemically pumped through the electrolyte, the catalytic activities and selectivities of $\mathrm{C}_{2}$ hydrocarbons are not changed [47]. In the case of the $\mathrm{Ag} / \mathrm{Bi}_{2} \mathrm{O}_{3}$ system the catalytic activity and selectivity to $\mathrm{C}_{2}$ hydrocarbons, when oxygen is pumped electrochemically, is greater than when it is introduced from the gas phase under the conditions of low oxygen feed rates. At higher feed rates, the catalyst performance is independent of the method of oxygen introduction.

The above results show that the enhanced oxygen concentration caused by electrochemical pumping influences the catalyst activity and the $\mathrm{C}_{2}$ hydrocarbon selectivity, but this depends on the nature of the catalyst. For pure $\mathrm{Ag}$, no influence of the rate of the electrochemical oxygen pumping on the activity of the catalyst was observed [47]. In the $\mathrm{Li} / \mathrm{MgO}-\mathrm{Ag}$ system, the activity of the catalyst decreases [238], while for the $\mathrm{Bi}_{2} \mathrm{O}_{3}-\mathrm{Ag}$ system, an increase in the activity and selectivity was observed with increased rates of oxygen pumping [47]. This behavior is probably caused by the selective influence of electrochemical 
oxygen pumping on the nature of the active sites on the catalyst surface.

Interesting results concerning the production of $\mathrm{C}_{2}$ hydrocarbons from methane in the yttria-stabilized zirconia fuel cell system were obtained by Pujare and Sammels in their preliminary work [250]. They used $\mathrm{Pt} / \mathrm{Sm}_{2} \mathrm{O}_{3} / \mathrm{La}_{0.89} \mathrm{Sr}_{0.10} \mathrm{MnO}_{3}$ catalysts and obtained $\mathrm{C}_{2}$ hydrocarbons with a selectivity of $11 \%$. The distribution of the oxidative dimerization products was as follows: $58 \% \mathrm{C}_{2} \mathrm{H}_{4}, 37 \% \mathrm{C}_{2} \mathrm{H}_{6}$, and $4 \% \mathrm{C}_{2} \mathrm{H}_{2}$.

Overall progress in this field has been slow, although the available results are promising. It appears certain that only highly conductive solid or nonaqueous electrolytes should be used for the electrochemical coupling of methane in fuel cell systems. The noble metals as electrode catalysts are not useful. Similarly to the gas phase conversion case, the best results have been achieved with highly alkaline oxides $(\mathrm{Li} / \mathrm{MgO}$, $\mathrm{Sm}_{2} \mathrm{O}_{3}, \mathrm{Bi}_{2} \mathrm{O}_{3}$ ) mixed with or coated on porous silver catalysts.

For further progress in the electrochemical coupling of methane, it seems essential to discover selective and active catalysts, as well as suitable solvents and/or electrolytes to allow a reduction of the temperature. Optimization of other experimental conditions is also important.

\section{CONCLUSIONS}

The oxidative coupling of methane is one of the promising processes for converting methane directly into higher hydrocarbons. As reviewed in the present work, the process has some shortcomings as well as good features. The reaction can be carried out without problems such as corrosion of the reactor materials, and $\mathrm{C}_{2}$ yields as high as $30 \%$ and very high selectivities ( $>90 \%$ ) have been achieved. On the other hand, the reaction requires high temperatures and the products are almost limited to $\mathrm{C}_{2}$. The mechanism of the reaction is not simple because the process proceeds both heterogeneously and homogeneously. That the blank tests without catalyst produce very small or negligible amounts of reaction products is somewhat misleading. The reaction in an empty reactor is limited by poor production of $\mathrm{CH}_{3} \cdot$ radicals. Once the formation of the radicals is initiated by a catalyst, the gas phase reactions proceed extensively. For this reason an active catalyst is essential for the reaction to proceed efficiently.

As mentioned in section III.D, data collected from the literature seem to indicate that, at high temperatures, the coupling reaction is controlled mainly by homogeneous processes. If so, there will be a maximum yield of hydrocarbons which cannot be changed at these high 
temperatures simply by increasing the amount or the activity of the catalyst. It does not mean, however, that efforts for improving catalysts are fruitless. More selective catalysts are essential at high temperatures to minimize the surface formation of $\mathrm{CO}_{x}$ and the destruction of methyl radicals and hydrocarbon products. Higher ratios of ethylene to ethane and lower reaction temperatures can also be expected from the development of improved catalysts. At high temperatures where the homogeneous reactions dominate, more information is required also on the engineering aspect of the process. One example is the effect of the empty space in the catalyst bed on the product yield. The volume of the gas phase in the catalyst bed should play an important role at high temperatures. It will be useful, therefore, to devise a rapid removal of the products from the reaction zone, for example, by quenching. Better control of oxygen supply to the catalyst bed could also improve the yield of $\mathrm{C}_{2}$.

Methane conversion by other processes is interesting and promising. However, these investigations have begun rather recently, and it is premature to critically assess these approaches.

\section{ACKNOWLEDGMENTS}

The financial support of CANMET, Energy, Mines and Resources Canada (No. 23440-7-9057/01GS and No. 23440-8-9040/01-SZ), and joint financial support of CANMET, Energy, Mines and Resources Canada and Alberta Research Council, Canada (No. 23440-7-9175/01SQ) are gratefully acknowledged.

\section{REFERENCES}

[1] H. Mimoun, New J. Chem., 11, 513 (1987).

[2] JANAF Thermochemical Tables (2nd ed.), National Bureau of Standards, Washington, DC, 1971.

[3] G. E. Keller and M. M. Bhasin, J. Catal., 73, 9 (1982).

[4] J. S. Lee and S. T. Oyama, Catal. Rev. - Sci. Eng., 30, 249 (1988).

[5] R. Pitchai and K. Klier, Catal. Rev. -Sci. Eng., 28, 13 (1986).

[6] J. Sofranko, J. J. Leonard, and C. A. Jones, J. Catal., 103, 302 (1987).

[7] C. A. Jones, J. J. Leonard, and J. A. Sofranko, J. Catal., 103, 311 (1987)

[8] A. M. Gaffney, C. A. Jones, J. J. Leonard, and J. A. Sofranko, J. Catal., 114, 422 (1988). 
[9] S. Mahajan, D. M. Nicholas, F. Sherwood, W. R. Menzies, and L. F. Albright, Am. Chem. Soc., Div. Petr. Chem.. Prepr., 19, 663 (1974).

[10] S. Mahajan and L. F. Albright, Am. Chem. Soc., Div. Petr. Chem., Prepr., 19, 676 (1974).

[11] J. A. Labinger and K. C. Ott, J. Phys. Chem., 91, 2682 (1987).

[12] J. A. Labinger, K. C. Ott, S. Mehta, H. K. Rockstand, and S. Zoulmalan, J. Chem. Soc., Chem. Commun., 543 (1987).

[13] C. A. Jones, J. J. Leonard, and J. A. Sofranko, U.S. Patents 4,443,644, $4,443,645,4,443,646,4,443,647,4,443,648,4,443.649$, and 4,444,984 (1984).

[14] W. Hinsen, W. Bytyn, and M. Baerns, Proc. 8th Int. Congr. Catal., Berlin, 1984, Verlag Chemie, 1985, Vol. 3, p. 581.

[15] H. Imai, T. Tagawa, and N. Kamide, J. Catal., 106, 394 (1987).

[16] M. Y. Lo, S. K. Agarwal, and G. Marcelin, J. Catal., 112, 168 (1988).

[17] D. J. Driscoll, M. Wilson, J-X. Wang, and J. H. Lunsford, J. Am. Chem. Soc., 107, 58 (1985).

[18] T. Ito and J. H. Lunsford, Nature, 314, 721 (1985).

[19] T. Fang and C-T. Yeh, J. Catal., 69, 227 (1981).

[20] K. Otsuka, K. Jinno, and A. Morikawa, Chem. Lett., 499 (1985).

[21] J. G. McCarty, M. A. Quinlan, and K. M. Sancier, ACS. Div. Fuel Chem. Preps., 33 (3), 363 (1988).

[22] S. J. Korf, J. A. Roos, N. A. de Bruijn, J. G. van Ommen, and J. R. H. Ross, Catal. Today, 2, 535 (1988).

[23] J. A. S. P. Carreiro, G. Follmer L. Lehmann, and M. Baerns, Proc. 9th Int. Congr. Catal., Calgary 1988 (M. J. Phillips and M. Ternan, eds.), Chem. Inst. of Canada 1988, Vol. 2, p. 891.

[24] K. Aika, T. Moriyama, N. Takasaki, and E. Iwamatsu, J. Chem. Soc. Chem. Commun., 1210 (1986).

[25] J. A. S. P. Carreiro, and M. Baerns, React. Kin. Catal. Lett., 35, 349 (1987).

[26] B. Yingli, Z. Kaiji, J. Yutao, T. Chiwen, and Y. Xiangguong, Appl. Catal., 39, 185 (1988).

[27] T. Ito, T. Tashiro, T. Watanabe, K. Toi, and I. Ikemoto, Chem. Lett., 1723 (1987).

[28] K. Fujimoto, S. Hashimoto, K. Asami, and H. Tominaga, Chem. Lett., 2157 (1987).

[29] T. Doi, Y. Utsumi, and I. Matsuura, Proc. 9th Int. Congr. Catal., Calgary 1988 (M. J. Phillips and M. Ternan, eds.), Chem. Inst. of Canada 1988, Vol. 2, p. 937.

[30] R. Burch, G. D. Squire, and S. C. Tsang, Appl. Catal., 43, 105 (1988).

[31] M. Iwamoto and J. H. Lunsford, J. Phys. Chem., 84, 3079 (1980).

[32] J.-X. Wang and J. H. Lunsford, J. Phys. Chem., 90, 5883 (1986).

[33] E. Iwamatsu, T. Moriyama, N. Takasaki, and K. Aika, J. Chem. Soc., Chem. Commun., 19 (1987). 
[34] E. Iwamatsu, T. Moriyama, N. Takasaki, and K. Aika, J. Catal., 113, 25 (1988).

[35] K. Aika and T. Nishiyama, Proc. 9th Int. Congr. Catal Calgary 1988 (M. J. Phillips and M. Ternan, eds.), Chem. Inst. of Canada, 1988, Vol. 2, p. 907.

[36] J. P. Bartek, J. M. Hupp, J. F. Brazdil, and R. K. Grasselli, Catal. Today, 3, 117 (1988).

[37] W. Bytyn and M. Baerns, Appl. Catal., 28, 199 (1986).

[38] I. T. Ali Emesh and Y. Amenomiya, J. Phys. Chem., 90, 4785 (1986).

[39] J. A. Ross, A. G. Bakker, H. Bosch, J. G. van Ommen, and J. R. H. Ross, Catal. Today, 1, 133 (1987).

[40] K. Aika, M. Isobe, K. Kido, T. Moriyama, and T. Onishi, J. Chem. Soc. Faraday 1, 83, 3139 (1987).

[41] G. W. Keulks and M. Yu, React. Kin. Catal. Lett., 35, 361 (1987).

[42] A. I. Suleimanov, E. G. Ismailov, S. M. Aliev, and V. D. Sokolovskii, React. Kin. Catal. Lett., 34, 51 (1987).

[43] K. Machida and M. Enyo, J. Chem. Soc., Chem Commun., 1639 (1987).

[44] N. Yamagata, K. Tanaka, S. Sasaki, and S. Okazaki, Chem. Lett., 81 (1987).

[45] M. Yu Sinev, V. N. Korchak, and O. V. Krylov, Kinet. Catal., 27, 1110 (1986). -

[46] K. Otsuka and M. Hatano, J. Catal., 108, 252 (1987).

[47] K. Otsuka, S. Yokoyama, and A. Morikawa, Chem. Lett., 319 (1985).

[48] K. D. Campbell, H. Zhang, and J. H. Lunsford, J. Phys. Chem., 92, 750 (1988).

[49] C. Mirodatos, V. Perrichon, H. C. Durupty, and P. Moral, Stud. Surf. Sci. Catal., 34, 183 (1987).

[50] K. D. Campbell and J. H. Lunsford, J. Phys. Chem., 92, 5792 (1988).

[51] J. M. DeBoy and R. F. Hicks, Ind. Eng. Chem. Res., 27, 1577 (1988).

[52] C. Lin, K. D. Campbell, J. Wang, and J. H. Lunsford, J. Phys. Chem., 90, 534 (1986).

[53] H. Imai and T. Tagawa, J. Chem. Soc. Chem. Commun., 52 (1986).

[54] H. Imai, T. Tagawa, N. Kamide, and S. Wada, Proc. 9th Int. Congr. Catal. Calgary 1988 (M. J. Phillips and M. Ternan, eds.), Chem. Inst. of Canada, 1988, Vol. 2, p. 952.

[55] T. Tagawa and H. Imai, J. Chem. Soc. Faraday Trans. I, 84, 923 (1988).

[56] J. E. France, A. Shamsi, L. C. Headley, and M. Q. Ahsan, AIChE 1988 Spring Nat. Meet., Paper 71e.

[57] J. M. DeBoy and R. F. Hicks, J. Catal., 113, 517 (1988).

[58] H. L. Mitchell and R. H. Waghorne, U.S. Patents 4,172,810 (1980); 4,205,194 (1980); 4,239,658 (1980).

[59] K. Otsuka, K. Jinno, and A. Morikawa, J. Catal, 100, 353 (1986).

[60] A. M. Gaffney, U.S. Patent 4,499,323 (1985).

[61] K. Otsuka and T. Nakajima, J. Chem. Soc., Faraday Trans. I, 83, 1315 (1987). 
[62] A. Ekstrom and J. A. Lapszewicz, J. Chem. Soc., Chem. Comm., 797 (1988); ACS, Div. Petr. Chem. Prepr., 33 (3), 430 (1986).

[63] A. Ekstrom and J. A. Lapszewicz, J. Am. Chem. Soc., 110, 5226 (1988).

[64] H. J. F. Doval, O. A. Scelza, and A. A. Castro, React. Kin. Catal. Lett., 34, 143 (1987).

[65] K. Otsuka, Q. Liu, and A. Morikawa, J. Chem. Soc., Chem. Commun., 586 (1986).

[66] J. A. Roos, A. G. Bakker, H. Bosch, J. G. van Ommen, and J. R. H. Ross, Catal. Today, 1, 133 (1987).

[67] J. A. Roos, S. J. Kort, A. G. Bakker, N. A. De Bruijn, J. G. van Ommen, and J. R. H. Ross, in Methane Conversion (D. M. Bibby, C. D. Chang, R. F. Howe, and S. Yurchak, eds.), Elsevier, 1988, p. 427.

[68] N. R. Foster, Applied Catal., 19, 1 (1985).

[69] C. F. Cullis, D. E. Keene, and D. L. Trimm, J. Catal., 19, 378 (1970).

[70] K. Otsuka, Q. Liu, M. Hatano, and A. Morikawa, Chem. Lett., 903 (1986).

[71] K. Otsuka and T. Komatsu, J. Chem. Soc., Chem. Commun., 388 (1987).

[72] M. Hatano and K. Otsuka, Inorg. Chim. Acta, 146, 243 (1988).

[73] G. S. Lane and E. E. Wolf, Proc. 9th Int. Congr. Catal. Calgary 1988 (M. J. Phillips and M. Ternan, eds.), Chem. Inst. of Canada, 1988, Vol. 2, p. 944.

[74] S. L. Kaliaguine, B. N. Shelimov, and V. B. Kazansky, J. Catal., 55, 384 (1978).

[75] M. Yu. Sinev, V. N. Korchak, and O. V. Krylov, Kinet. Catal., 27, 1188 (1987).

[76] T. E. Helton, A. M. Gadallah, and R. G. Anthony, AIChE 1988 Spring National Meeting, paper 71e.

[77] N. D. Spencer, J. Catal., 109, 187 (1988).

[78] S. Kasztelan and J. B. Moffat, J. Catal., 106, 512 (1987).

[79] W. Ueda and J. M. Thomas, Proc. 9th Int. Congr. Catal. Calgary 1988 (M. J. Phillips and M. Ternan, eds.), Chem. Inst. of Canada, 1988, Vol. 2, p. 960.

[80] A. B. Anderson, J. J. Maloney, and J. Yu, J. Catal., 112, 392 (1988).

[81] C. A. Jones, and J. A. Sofranko, U.S. Patent 4,499,322 (1985).

[82] Kh. M. Minachev, N. Ya. Usachev, Yu. S. Khodakov, L. L. Kozlov, V. N. Udut, and O. A. Fomin, Bull. Acad. Sci. USSR. Div. Chem. Sci., 1544 (1985).

[83] Kh. M. Minachev, N. Ya. Usachev, Yu. S. Kohodakov. V. N. Udut, and P. A. Makarov, Bull. Acad. Sci. USSR Div. Chem. Sci., 36, 1975 (1987).

[84] C. A. Jones, J. J. Leonard, J. A. Sofranko, and H. P. Withers, U.S. Patent 4,523,049 (1985).

[85] J. A. Sofranko, J. J. Leonard, C. A. Jones, A. M. Gaffney, and H. P. Withers, Catal. Today, 3, 127 (1988). 
[86] C. A. Jones, J. Leonard, and J. A. Sofranko, U.S. Patent 4,560,821 (1985).

[87] C. A. Jones and J. A. Sofranko, U.S. Patent 4, 523,050 (1985).

[88] M. Mazurek, U.S. Patent 4,678,862 (1987).

[89] J. M. Thomas, X. Kuan, and J. Stachurski, J. Chem. Soc., Chem. Commun., 162 (1988).

[90] G. Koenig, Ger. Offen. DE 3, 101,024 (1982).

[91] J. R. Anderson and P. Tsai, Appl. Catal., 19, 141 (1985).

[92] V. Yu. Bychkov, M. Yu. Sinev, B. N. Kuznetsov, E. L. Aptekar, V. N. Korchak, M. G. Chudinov, and O. V. Krylov, Kinet. Katal., 28, 580 (1987).

[93] E. Gretz, T. F. Oliver, and A. Sen, J. Amer. Chem. Soc., 109, 8109 (1987).

[94] G. J. Hutchings, M. S. Scurrell,.and J. R. Woodhouse, J. Chem. Soc., Chem. Commun., 1388 (1987).

[95] M. Yu. Sinev, V. N. Korchak, and O. V. Krylov, Proc. 9th Int. Congr. Catal. Calgary 1988 (M. J. Phillips and M. Ternan, eds.), Chem. Inst. of Canada, 1988, Vol. 2, p. 968.

[96] H.-S. Zhang, J.-X. Wang, D. J. Driscoll, and J. H. Lunsford, J. Catal., 112, 366 (1988).

[97] A. H. P. Hall and J. J. McCarroll, Eur. Pat. Appl. 86306341.8 (1986).

[98] G. J. Hutchings, M. S. Scurrell, and J. R. Woodhouse, Appl. Catal., 38, 157 (1988).

[99] W. Hinsen and M. Baerns, Chemiker-Zeitung, 107, 223 (1983).

[100] M. Baerns and W. Hinsen, Ger. Offen. DE 3237079A1 (1982).

[101] H. Meng and A. R. Sanger, Appl. Catal., 32, 347 (1987).

[102] J. F. Brazdil, R. G. Teller, J. P. Bartek, and R. K. Grasselli, U.S. Patent 4,665,259 (1987).

[103] K. Asami, S. Hashimoto, T. Shikada, K. Fujimoto, and H. Tominaga, Chem. Lett., 1233 (1986).

[104] M. Yu. Sinev, G. A. Vorobieva, and V. N. Korchak, Kinet. Katal., 27, 1164 (1986).

[105] K. Asami, S. Hashimoto, T. Shikada, K. Fujimoto, and H. Tominaga, Ind. Eng. Chem. Res., 26, 1485 (1987).

[106] M.-Y. Lo, S. K. Agarwal, L. G. Galya, and G. Marcelin, Catal. Today, 3, 137 (1988).

[107] S. P. Mehandru, A. B. Anderson, and J. F. Brazdil, J. Chem. Soc., Faraday Trans I, 83, 463 (1987).

[108] K. Otsuka, and T. Komatsu, Chem. Lett., 483 (1987).

[109] J. B. Kimble and J. H. Kolts, Energy Progress, 6, 226 (1986).

[110] J. B. Kimble and J. H. Kolts, Chemtech., 501 (1987).

[111] T. Ito, J. Wang, C. Lin, and J. H. Lunsford, Am. Chem. Soc., 107, 5062 (1985).

[112] I. Matsuura, T. Doi, and Y. Utsumi, Chem. Lett., 1473 (1987). 
[113] T. Moriyama, N. Takasaki, E. Iwamatsu, and K. Aika, Chem. Lett., 1165 (1986).

[114] Z. K. Yingli, Y. Jiang, C. Teng, and X. Yang, Appl. Catal., 39, 185 (1988).

[115] J. M. DeBoy, and R. F. Hicks, J. Chem. Soc.. Chem. Commun., 982 (1988).

[116] K. Otsuka, Q. Liu, M. Hatano, and A. Morikawa, Chem. Lett., 467 (1986).

[117] I. Matsuura, Y. Utsumi, M. Nakai, and T. Doi, Chem. Lett., 1981 (1986).

[118] H. Nagamoto, K. Amanuma, H. Nobutomo, and H. Inoue, Chem. Lett., 237 (1988).

[119] K. Otsuka and T. Nakajima, Inorg. Chim. Acta, 120, L27 (1986).

[120] K. Otsuka, Y. Shimizu, and T. Komatsu, Chem. Lett., 1835 (1987).

[121] T. Tagawa and H. Imai, React. Kinet. Catal. Lett., 37, 115 (1988).

[122] K. Otsuka, Q. Liu, and A. Morikawa, J. Chem. Soc.. Chem. Commun., 586 (1986).

[123] C-H. Lin, T. Ito, J-X. Wang, and J. H. Lunsford, J. Am. Chem. Soc., 109, 4808 (1987).

[124] C-H. Lin, J-X. Wang, and J. H. Lunsford, J. Catal., 111, 302 (1988).

[125] D. J. C. Yates and N. E. Zlotin, J. Catal., 111, 317 (1988).

[126] P. Berlowitz, D. J. Driscoll, J. H. Lunsford, J. B. Butt, and H. H. Kung, Comb. Sci. Technol., 40, 317 (1984).

[127] I. G. Murgulescu and I. A. Schneider, J. Pract. Chem., 18, 121 (1962).

[128] H. Wroblowa, B. J. Priesma, and J. O’M. Bockris, J. Electroanal. Chem., 6, 401 (1963).

[129] W. T. Grubb and C. J. Michalske, J. Electrochem. Soc., 111, 1015 (1964).

[130] W. T. Grubb, J. Electrochem. Soc., 111, 1086 (1964).

[131] P. J. Lucchesi, J. L. Carter, and J. H. Sinfelt, J. Am. Chem. Soc., 86, 1494 (1964).

[132] L. W. Niedrach, J. Electrochem. Soc., 113, 645 (1966).

[133] G. F. Taylor, S. J. Thomson, and G. Webb, J. Catal., 12, 150 (1968).

[134] A. H. Taylor and S. B. Brummer, J. Phys. Chem., 73, 2397 (1969).

[135] S. B. Brummer and M. J. Turner, Proc. 23rd Annual Power Sources Conf., 1969, p. 26.

[136] J. O'M. Bockris, E. Gileadi, and G. E. Stoner, J. Phys. Chem., 73, 427 (1969).

[137] C. Kemball, Catal. Rev., 5, 33 (1971).

[138] Yu. B. Vasiliev, V. S. Bagotskii, and O. A. Khazowa, Elektrokhimiya, 11, 1505 (1975).

[139] E. A. Kolyadko, M. V. Menyailova, and V. I. Podlovchenko, Elektrokhimiya, 13, 273 (1977).

[140] A. Sarkany, K. Matusek, and P. Tetenyi, J. Chem. Soc.. Faraday Trans. I, 73, 1699 (1977). 
[141] P. Tetenyi, L. Guczi, and A. Sarkany, Acta Chim. Acad. Sci. Hung., 97, 221 (1978).

[142] M. G. Sustersic, R. Cordova, W. E. Triaca, and A. J. Arvia, J. Electrochem. Soc., 127, 1242 (1980).

[143] A. M. Castro Luna, A. Delgado, and A. J. Arvia, An. Asoc. Quim. Argent., 69, 301 (1981).

[144] W. Lisowski and R. Dus, Surf. Sci., 118, 208 (1982).

[145] K. Tanaka, I. Yaegashi, and K. Aomura, J. Chem. Soc., Chem. Commun., 938 (1982).

[146] S. Palfi, W. Lisowski, M. Smutek, and S. Cerny., J. Catal., 88, 300 (1984).

[147] I. Muzyka, S. A. Zubkov, V. Yu. Borovkov, and V. B. Kazanskii, Dokl. Akad. Nauk SSSR. Ser. Fiz. Khim., 284, 391 (1985).

[148] M. A. Quinlan, B. J. Wood, and H. Wise, Chem. Phys. Lett., 118, 478 (1985).

[149] D. L. Coche and C. Yoon, in Rapidly Quenched Metals (S. Steeb and H. Warlimont, eds.), Elsevier 1985, p. 1497.

[150] R. J. Madix, Science, 233, 1159 (1986).

[151] Po-Kang Wang, J.-P. Ansermet, S. L. Rudaz, Z. Wang, S. Shore, C. P. Slichter, and J. H. Sinfelt, Science, 234, 35 (1986).

[152] M. B. Lee, Q. Y. Yang, S. L. Tan, and S. T. Ceyer, J. Chem Phys,, 85, 1693 (1986).

[153] S. P. Mehandru, A. B. Anderson, and J. F. Brazdil, J. Am. Chem. Soc., 110, 1715 (1988).

[154] P. J. Robertson, M. S. Scurrell, and C. Kemball, J. Chem. Res., (S) 36 (1977); (M) 0501 (1977).

[155] Li. Quanzhi and Y. Amenomiya, Appl. Catal., 23, 173 (1986).

[156] M. F. Hoq and K. J. Klabunde, J. Am. Chem. Soc., 108, 2114 (1986).

[157] G. I. Gorodec, Teor. Eksperim. Khim., Akad. Nauk Ukr. SSR, 1, 755 (1965).

[158] G. K. Boreskov, Kinet. Katal., 8, 1020 (1967).

[159] G. K. Boreskov, V. V. Popovsky, and V. A. Sazonov, Proc. 4th Int. Congr. Catal., Moscow 1968, Vol. 2, p. 580.

[160] D. J. Driscoll and J. H. Lunsford, J. Phys. Chem., 89, 4415 (1985).

[161] M. Yu. Sinev, V. N. Korchak, and O. V. Krylov, Kinet. Katal., 27, 1274 (1986).

[162] K. Otsuka, A. A. Said, K. Jinno, and T. Komatsu, Chem. Lett., 77 (1987).

[163] J. X. Wang and J. H. Lunsford., J. Phys. Chem., 90, 3890 (1986).

[164] K. Otsuka and K. Jinno, Inorg. Chim. Acta, 121, 237 (1986).

[165] K. D. Campbell, E. Morales, and J. H. Lunsford, J. Am. Chem. Soc., 109, 7900 (1987).

[166] P. F. Nelson, C. A. Lukey, and N. W. Cant, J. Phys. Chem., 92, 6176 (1988).

[167] M. Utiyama, H. Hattori, and K. Tanabe, J. Catal., 53, 237 (1978). 
[168] G. Martin and C. Mirodatos, J. Chem. Soc., Chem. Commun., 1393 (1987).

[169] C. Mirodatos and G. A. Martin, Proc. 9th Int. Congr. Catal., Calgary 1988 (M. J. Phillips and M. Ternan, eds.), Chem. Inst. of Canada, 1988, Vol. 2, p. 899.

[170] K. Asami, S. Hashimoto, T. Shikada, K. Fujimoto, and H. Tominaga, Ind. Eng. Chem. Res., 26, 1485 (1987).

[171] G. J. Hutchings, J. R. Woodhouse, and M. S. Scurrell, Proc. 9th Int. Congr. Catal. Calgary 1988 (M. J. Phillips and M. Ternan, eds.), Chem. Inst. of Canada 1988, Vol. 2, p. 923.

[172] G. J. Hutchings, J. R. Woodhouse, and M. S. Scurrell, Proc. 9th Intern. Congr. Catal., Calgary 1988 (M. J. Phillips and M. Ternan, Chem. Inst. of Canada 1988, Vol. 5, p. 335.

[173] K. Asami, T. Shikada, K. Fujimoto, and H. Tominaga, Ind. Eng. Chem. Res., 26, 2348 (1987).

[174] K. T. Amorebieta and A. J. Colussi, J. Phys. Chem., 92, 4576 (1988).

[175] M. Yu. Sinev, V. N. Korchak, and D. V. Krylov, Kinet. Katal., 28, 1376 (1987).

[176] O. V. Bueyskaya, A. I. Suleimanov, S. M. Aliev, and V. D. Sokolovskii, Keact. Kinet. Catal. Lett., 33, 223 (1987).

[177] N. W. Cant, C. A. Lukey, P. F. Nelson, and R. J. Tyler, J. Chem. Soc., Chem. Commun., 766 (1988).

[178] G. S. Lane and E. E. Wolf, J. Catal., 113, 144 (1988).

[179] M. Anpo, M. Sunamoto, T. Doi, and I. Matsuura, Chem. Lett., 701 (1988).

[180] D. J. Driscoll, W. Martin, J. Wan, and J. H. Lunsford, J. Am. Chem. Soc., 107, 58 (1985).

[181] H. S. Zhang, J. X. Wang, D. J. Driscoll, and J. H. Lunsford, Am. . Chem. Soc.. Div. Fuel Chem., Prepr., 32, 242 (1987).

[182] K. Otsuka, Q. Liu, and A. Morikawa, Inorg. Chim. Acta, 118, L23 (1986).

[183] K. Otsuka and T. Komatsu, Chem. Lett., 1955 (1986).

[184] G. J. Hutchings, M. S. Scurrell, and J. R. Woodhouse, J. Chem. Soc., Chem. Commun., 1862 (1987).

[185] H. M. N. van Kasteren, J. W. M. H. Geerts, and K. van der Wiele, Proc. 9th Int. Congr. Catal. Calgary 1988 (M. J. Phillips and M. Ternan, eds.), Chem. Inst. of Canada 1988, Vol. 2, p. 930.

[186] R. S. Liu, M. Iwamoto, and J. H. Lunsford, J. Chem. Soc.. Chem. Commun., 78 (1982).

[187] A. N. Shigapov, M. A. Novozhilova, S. N. Vereshchagin, A. G. Anshits, and V. D. Sokolovskii, React. Kinet. Catal. Lett., 37, 397 (1988).

[188] K. Wohlfahrt, M. Bergfeld, and H. Zengel, FRG Patent 3,503,664; CA, 105, 153683 (1986). 
[189] S. J. Korf, J. A. Roos, N. A. de Bruijn, J. G. van Ommen, and J. R. H. Ross, J. Chem. Soc.. Chem. Commun., 1433 (1987).

[190] M. Baerns, K. van der Wiele, and J. R. H. Ross, Catal. Today, 4, 471 (1989).

[191] S. S. Shepelev and K. G. Ione, Kin. Katal., 25, 347 (1984).

[192] W. Ueda and J. M. Thomas, J. Chem. Soc.. Chem. Commun., 1148 (1988).

[193] K. Asami, K. Omata, K. Fujimoto, and H. Tominaga, Energy Fuels, 2, 574 (1988).

[194] C. E. Taylor and R. P. Noceti, Proc. 9th Int. Congr. Catal., Calgary 1988 (M. J. Phillips and M. Ternan, eds.), Chem. Inst. Canada, 1988, Vol. 2, p. 990.

[195] K. Aika and T. Nishiyama, J. Chem. Soc, Chem. Commun., 70 (1988).

[196] K. Aika and J. H. Lunsford, J. Phys. Chem., 81, 1393 (1977).

[197] H. F. Liu, R. S. Liu, K. Y. Liew, R. E. Johnson, and J. H. Lunsford, J. Am. Chem. Soc., 106, 4117 (1984).

[198] Y. Barbaux, A. E. Elamrani, and J. P. Bonnelle, Catal. Today, 1, 147 (1987).

[199] S. S. Shepelev and K. G. Ione, React. Kinet. Catal. Lett., 23, 319 (1983).

[200] G. N. Kastanas, G. A. Tsigdinos, and J. Schwank, Appl. Catal., 44, 33 (1988).

[201] H. D. Gesser, N. R. Hunter, and L. Morton, U.S. Patent 4,618,732 (1986).

[202] G. J. Hutchings, M. S. Scurrell, and J. R. Woodhouse, J. Chem. Soc. Chem. Commum., 253 (1988).

[203] K. Asami, K. Omata, K. Fujimoto, and H. Tominaga, J. Chem. Soc. Chem. Comm., 1287 (1987).

[204] G. A. Olah, J. Am. Chem. Soc., 90, 2726 (1986).

[205] M. S. Scurrell, Appl. Catal., 34, 109 (1987).

[206] G. A. Olah, Acc. Chem. Res., 20, 422 (1987).

[207] M. S. Scurrell, Appl. Catal., 32, 1 (1987).

[208] M. Siskin and I. Mayer, U.S. Patent 4,094,924 (1978).

[209] G. A. Olah, U.S. Patent, 4,433,192 (1984); 4,467,130 (1984); 4,513,164 (1985).

[210] G. A. Olah, U.S. Patent 4,465,893 (1984)

[211] K. M. Dooley and B. C. Gates, J. Catal., 96, 347 (1985)

[212] G. A. Olah, D. Felberg, and K. Lammertsma, J. Am. Chem. Soc., 105, 6529 (1983).

[213] G. A. Olah, G. K. S. Prakash, and J. Soomer, Superacids, Wiley, New York, 1985.

[214] S. W. Benson, U.S. Patent 4,199,533 (1980).

[215] C. L. Garcia and D. E. Desasco, Appl. Catal., 29, 55 (1987).

[216] W. J. Kroenke and P. P. Nicholas, U.S. Patent, 4,467,127 (1984).

[217] M. H. Gorin and E. Gorin, U.S. Patent, 2,488,083 (1949). 
[218] C. D. Chang, A. J. Silvestri, and R. L. Smith, U.S. Patent, 3,894,105 (1975).

[219] E. J. Cairns, Adv. Electrochem. Eng., Vol. 8, Wiley Interscience, New York, 1971 , p. 337.

[220] A. H. Taylor and S. B. Brummer, J. Phys. Chem., 72, 2856 (1968).

[221] D. P. Summers and K. W. Frese Jr., Spring Meeting of the Electrochem. Soc., Atlanta. Georgia 1988, Extended Abstracts, Vol. 88-1, p. 17.

[222] J. Cassidy, S. B. Khoo, S. Pons, and M. Fleischman, J. Phys. Chem., 89, 3933 (1985).

[223] T. Otogawa, S. Zaromb, and J. R. Stetter, J. Electrochem. Soc., 132, 2951 (1985).

[224] K. Ogura and K. Takamagari, Nature, 319, 308 (1986).

[225] A. A. Adams and R. T. Foley, J. Electrochem. Soc., 126, 775 (1979).

[226] S. Y. Hsieh and K. M. Chen, J. Electrochem. Soc., 124, 1171 (1977).

[227] L. W. Niedrach and M. Tochner, J. Electrochem. Soc., 114, 17 (1967).

[228] L. W. Niedrach, J. Electrochem. Soc., 111, 1309 (1964).

[229] H. P. Fritz, J. Electroanal. Chem., 54, 181 (1974).

[230] Y. Harima and R. Morrison, J. Electroanal. Chem., 220, 173 (1987).

[231] P.-L. Fabre, J. Denvych, and B. Tremillon, Tetrahedron, 38, 2697 (1982)

[232] P. Sidheswaran, J. Electrochem. Soc. India, 28, 27 (1979).

[233] H. Binder, A. Köhling, and G. Sandstede, Adv. Energy Conv., 6, 135 (1966).

[234] H. Binder, A. Köhling, and G. Sandstede, Rev. Energie Prim., 1, 48 (1965).

[235] M. Bonnemay, G. Bronoel, D. Doniat, and J. P. Peasand, Am. Chem. Soc., Div. Fuel Chem.. Prep., 13, 221 (1969).

[236] S. B. Brummer, M. J. Turner, S. D. Kirkland, and H. Feng, Proc. Symp. Electrocatal., San Francisco 1974, p. 128.

[237] J. R. Ruft, in From Electrocatalysis to Fuel Cells (G. Sandstede, ed.), Univ. Washington, Seattle, 1972, p. 3.

[238] S. Seimanides and M. Stoukides, J. Electrochem. Soc., 133, 1535 (1986).

[239] R. Jasinski, J. Huff, S. Tomter, and L. Swette, Ber. Bunsenges. Phys. Chem., 68, 400 (1964).

[240] W. T. Grubb and C. J. Michalske, Nature, 201, 287 (1964).

[241] B. C. Nguyen, T. A. Lin, and D. M. Mason, J. Electrochem. Soc., 133, 1807 (1986).

[242] G. W. Walker and R. T. Foley, J. Electrochem. Soc., 128, 1502 (1981).

[243] H. Binder, A. Köhling, H. Krupp, K. Richter, and G. Sandstede, J. Electrochem. Soc., 112, 355 (1965).

[244] J. Weissbart and R. Ruka, J. Electrochem. Soc., 109, 723 (1962).

[245] L. W. Niedrach, J. Electrochem. Soc., 109, 1092 (1962).

[246] E. J. Cairns, J. Electrochem. Soc., 113, 1200 (1966). 
[247] D. Eng and M. Stoukides, Proc. 9th Int. Congr. Catal., Calgary 1988 (M. J. Phillips and M. Ternan, eds.), Chem. Inst. of Canada 1988, Vol. 2, p. 974.

[248] S. Seimanides, M. Stoukides, and A. Robbat, AIChE Symp. Ser., 1987. 83 (254, Electrochem. Eng. Appl.) 40.

[249] S. Seimanides and M. Stoukides, J. Catal., 88, 490 (1984).

[250] N. U. Pujare and A. F. Sammels, J. Electrochem. Soc., 135, 2544 (1987).

[251] H. Binder, A. Köhling, and G. Sandstede, in From Electrocatalysis to Fuel Cells (G. Sandstede, ed.), Univ. Washington, Seattle, 1972, p. 15.

[252] R. A. Goffe and D. M. Mason, J. Appl. Electrochem., 11, 447 (1981).

[253] H. A. Liebhafsky and W. T. Grubb, Am. Chem. Soc., Div. Fuel Chem., Prepr., 11, 134 (1967).

[254] B. G. Ong, C. C. Chiang, and D. M. Mason, Solid State Ionics, 3/4, 447 (1981).

[255] S. B. Brummer and M. J. Turner, J. Phys. Chem., 71, 3494 (1967).

[256] L. W. Niedrach, S. Gilman, and I. Weinstock, J. Electrochem. Soc., 112, 1161 (1965).

[257] A. A. Adams and H. J. Barger Jr., J. Electrochem. Soc., 121, 987 (1974)

[258] J. Giner, Electrochim. Acta, 8, 857 (1963).

[259] J. Giner, Electrochim. Acta, 9, 63 (1964).

[260] H. Tannenberger, in From Electrocatalysis to Fuel Cells (G. Sandstede, ed.), Univ. Washington, Seattle, 1972, p. 235.

[261] M. Stoukides and C. G. Vayenas, J. Electrochem. Soc., 131, 839 (1984).

[262] M. Stoukides and C. G. Vayenas, J. Catal., 70, 137 (1981).

[263] K. Otsuka, K. Suga, and I. Yamanaka, Chem. Lett., 317 (1988). 